Analysis of Radiation Doses from Operation of Postulated Commercial Spent Fuel Transportation Systems

Analysis of a System Containing a Monitored Retrievable Storage Facility

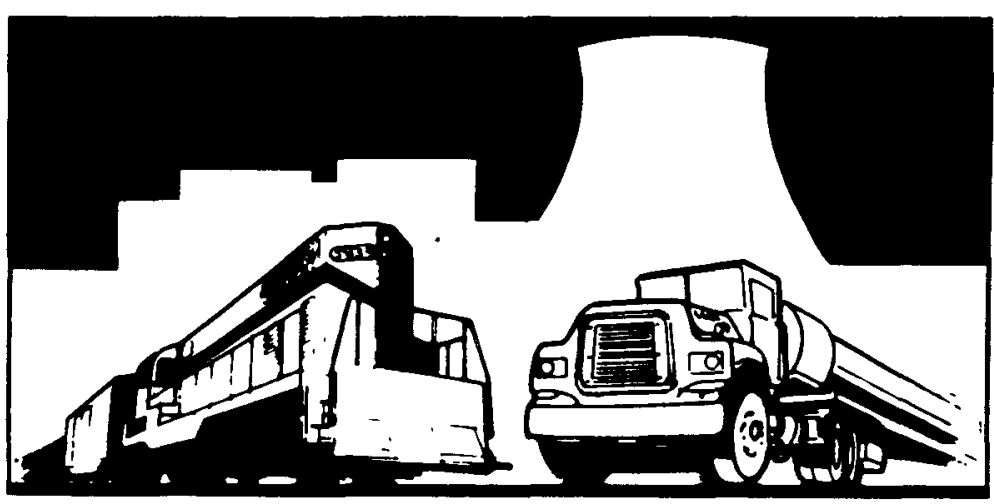

April 1992

Work Performed under Contract DE-AC06-76RLO 1830

Pacific Northwest Laboratory

Richland, Washington 99352

U.S. Department of Energy

Chicago Field Office

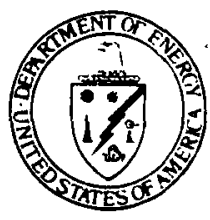




\section{DISCLAIMER}

This report was prepared as an account of work sponsored by an agency of the United States Government. Neither the United States Government nor any agency thereof, nor Battelle Memorial Institute, nor any of their employees, makes any warranty, expressed or implied, or assumes any legal liability or responsibility for the accuracy, completeness, or usefulness of any information, apparatus, product, or process disclosed, or represents that its use would not infringe privately owned rights. Reference herein to any specific commercial product, process, or service by trade name, trademark, manufacturer, or otherwise does not necessarily constitute or imply its endorsement, recommendation, or favoring by the United States Government or any agency thereof, or Battelle Memorial Institute. The views and opinions of authors expressed herein do not necessarily state or reflect those of the United States Government or any agency thereof.

Printed in the United States of America

Available to DOE and DOE contractors from the

Office of Scientific and Technical Information, P.O. Box 62, Oak Ridge, TN 37831; prices available from (615) 576-8401. FTS 626-8401.

Available to the public from the National Technical Information Service, U.S. Department of Commerce, 5285 Port Royal Rd., Springfield, VA 22161. 


\section{DISCLAIMER}

This report was prepared as an account of work sponsored by an agency of the United States Government. Neither the United States Government nor any agency Thereof, nor any of their employees, makes any warranty, express or implied, or assumes any legal liability or responsibility for the accuracy, completeness, or usefulness of any information, apparatus, product, or process disclosed, or represents that its use would not infringe privately owned rights. Reference herein to any specific commercial product, process, or service by trade name, trademark, manufacturer, or otherwise does not necessarily constitute or imply its endorsement, recommendation, or favoring by the United States Government or any agency thereof. The views and opinions of authors expressed herein do not necessarily state or reflect those of the United States Government or any agency thereof. 


\section{DISCLAIMER}

Portions of this document may be illegible in electronic image products. Images are produced from the best available original document. 


\title{
ANALYSIS OF RADIATION DOSES \\ FROM OPERATION OF POSTULATED COMMERCIAL SPENT FUEL TRANSPORTATION SYSTEMS \\ ANALYSIS OF A SYSTEM CONTAINING A MONITORED RETRIEVABLE STORAGE FACILITY
}

\section{By}

\author{
R. I. Smith \\ P. M. Daling \\ D. W. Faletti ${ }^{(a)}$
}

April 1992

Work performed under Contract DE-AC06-76RLO 1830

B \& R Code DB-04-01-03

\author{
Prepared for \\ U.S. Department of Energy \\ Chicago Field Office \\ Argonne, IL 60439

\section{Prepared by} \\ Pacific Northwest Laboratory \\ Richland, Washington 99352
}
U.S. Department of Energy Chicago Field Office

(a) Affiliated with Westinghouse Hanford Co. 



\section{ABSTRACT}

This addendum report extends the original study of the estimated radiation doses to the public and to workers resulting from transporting spent nuclear fuel from commercial nuclear power reactor stations through the federal waste management system (FWMS), to a system that contains a monitored retrievable storage (MRS) facility. The system concepts and designs utilized herein are consistent with those used in the original study (circa 1985-1987). Because the FWMS design is still evolving, the results of these analyses may no longer apply to the designs for casks and cask handling systems that are currently being considered.

Four system scenarios are examined and compared with the reference No-MRS scenario (all spent fuel transported directly from the reactors to the western repository in standard-capacity truck and rail casks). In Scenarios 1 and 2, an MRS facility is located in the eastern United States and ships either intact fuel assemblies or consolidated fuel rods and compacted assembly hardware in canisters. In Scenarios 3 and 4, an MRS facility is located in the western United States and ships either intact fuel assemblies or consolidated fuel rods and compacted assembly hardware in canisters.

The addition of an MRS facility to the system results in additional cask unloading and loading operations (at the MRS), which increase the radiation dose received by FWMS workers by from 134 to 237 person-rem per year, depending upon the scenario.

When the MRS facility is located in an eastern region of the U.S., those reactors located in the western region of the country ship spent fuel directly to the western repository (about $350 \mathrm{MTU} / \mathrm{yr}$ ). The remaining $2650 \mathrm{MTU} / \mathrm{yr}$ are shipped via the shorter transport routes between the eastern reactors and the MRS. The radiation dose received by the public from spent fuel transport is reduced by about 193 person-rem per year, relative to the reference No-MRS scenario due to the shorter routes between the eastern reactors and the eastern MRS and the exclusive use of extra-large capacity rail casks on dedicated trains between the MRS and the western repository. Similarly, the radiation 
dose received by the transport workers is reduced by about 76 person-rem/yr, relative to the reference No-MRS scenario.

When the MRS facility is located in the western U.S., all $3000 \mathrm{MTU} / \mathrm{yr}$ of spent fuel is transported to the MRS facility using standard-capacity truck and rail casks. The radiation dose received by the public from spent fuel transport is increased by about 43 person-rem per year, relative to the No-MRS scenario, due to the longer transport distances. Similarly, the radiation dose received by the transport workers is increased by about 46 person-rem/yr, relative to the reference No-MRS scenario.

The radiation dose received by the MRS and repository workers is affected significantly by whether or not the spent fuel assemblies are consolidated at the MRS and by how the residual hardware from the consolidated assemblies is treated for packaging prior to shipment. With an MRS facility in the system, the facility worker doses are reduced for the consolidation scenarios relative to the intact fuel scenarios, but all of the MRS scenarios result in a larger cumulative annual dose to system workers than the reference No-MRS scenario. 


\section{CONTENTS}

ABSTRACT .............................

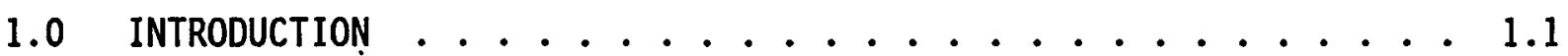

2.0 SUMMARY $\ldots \ldots \ldots . \ldots \ldots . \ldots \ldots$

3.0 STUDY BASES AND SYSTEM ASSUMPTIONS . . . . . . . . . 3.1

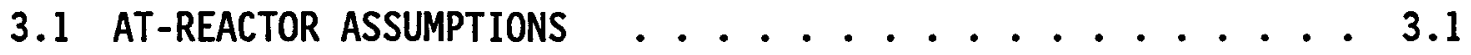

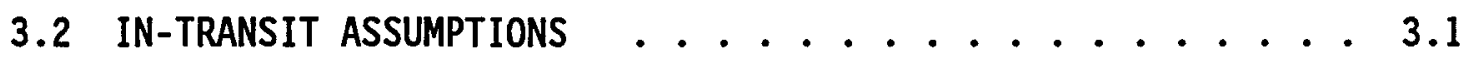

3.2.1 At-MRS Assumptions . . . . . . . 3.5

3.2.2 At-Repository Assumptions . . . . . . . 3.6

3.2.3 Dose Rate Assumptions . . . . . . . 3.6

4.0 RADIATION DOSE ESTIMATES FOR FACILITY OPERATIONS . . . . . 4.1

4.1 CASK RECEIVING, LOADING, AND SHIPPING OPERATIONS AT MRS . • 4.1

4.2 CASK RECEIVING OPERATIONS AT THE REPOSITORY . . . . . 4.6

5.0 ANALYSIS OF IN-TRANSIT OPERATIONS AND RADIATION DOSES $\ldots \ldots . .5$

5.1 ANALYSIS OF IN-TRANSIT TRANSPORT OPERATIONS AND DOSES

(from-reactor truck shipments) .......... 5.1

5.1 .1 In-Transit Operations .......... 5.1

5.1.2 Collective Doses from Truck Shipments . . . . . 5.2

5.1.3 Maximally Exposed Individuals from Truck

5.2 ANALYSIS OF IN-TRANSIT TRANSPORT OPERATIONS AND DOSES $\ldots 5.8$ (from-reactor rail shipments)

5.2.1 In-Transit Operations ......... 5.8

5.2.2 Collective Doses from General Freight Rail Shipments ................ 5.9

5.2.3 Maximally Exposed Individuals from General Freight Rail Shipments ........... 5.10 
5.3 ANALYSIS OF IN-TRANSIT TRANSPORT OPERATIONS AND DOSES

(from-MRS dedicated train rail shipments) ....... 5.14

5.3.1 In-Transit Operations ........... 5.15

5.3.2 Collective Doses from Dedicated Rail Shipments . . 5.16

5.3.3 Maximally Exposed Individuals from Dedicated Train Shipments ............ 5.23

5.4 ANNUAL SYSTEM RADIATION DOSES FROM IN-TRANSIT OPERATIONS • 5.25

6.0 COMPARISON OF THE MRS SCENARIOS WITH THE NO-MRS SCENARIO $\ldots \ldots .6 .1$

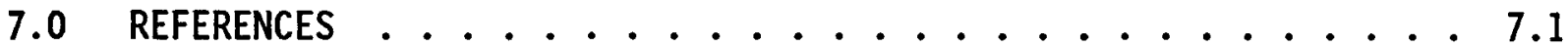

APPENDIX A - TIME/DISTANCE/DOSE CALCULATIONS FOR 150-TON CASK

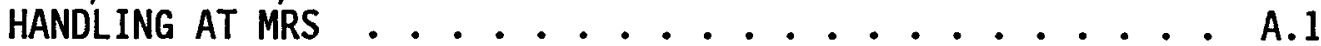

APPENDIX B - TIME/DISTANCE/DOSE CALCULATIONS FOR 150-TON CASK

HANDLING AT THE REPOSITORY ............ B.1

APPENDIX $c$ - IN-TRANSIT DOSE CALCULATIONS .......... c.1 


\section{FIGURES}

1.1 Waste Management System Configurations Analyzed in This

Study ..................... 1.2

2.1 Distribution of Estimated Annual Dose by Recipient Category . . 2.2

5.1 Comparison of Estimated Annual In-Transit Radiation Doses

for Systems With and Without an MRS Facility . . . . . . . . 5.27

6.1 Distribution of Estimated Annual Dose by Recipient Category . . 6.2

6.2 Distribution of Estimated Annual Dose by System Location . . . 6.3

\section{TABLES}

2.1 Estimated Annual Radiation Doses to Facility Workers, Transportation Workers, and the General Public Resulting from Spent Fuel Transport . . . . . . . . . . . . . . . . 2.1

2.2 Average Annual Radiation Doses to Facility Workers from Transportation-Related Activities, by Worker Category . . . . 2.3

3.1 Shipping Distances and Trave] Fractions for Each Transport Let in the MRS System ............... 3.2

3.2 Capacities of Truck, General Freight Rail, and Dedicated Train Shipments ............... 3.3

4.1 Handling Activities and Associated Worker Radiation Doses for the 150-Ton Rail Cask at the MRS and Repository Facilities . . 4.2

4.2 Estimated Radiation Doses per Cask Loaded, and Annual Doses to MRS Facility Workers for Loading the 150-ton Cask . . . . . . 4.4

4.3 Estimated Annual Radiation Doses to Workers at the Western MRS Facility from Transportation-Related Activities . . . . . 4.5

4.4 Estimated Radiation Doses per Cask Unloaded and Annual Doses to Repository Workers for Unloading Casks Containing a Total of 3000 MTU per Year of Intact Spent Fuel . . . . . . . . 4.7

5.1 Parameters/Algorithms Used to Calculate Routine Radiation Doses for Truck Shipments ................. 5.3

5.2 Summary of Estimated In-Transit Radiation Doses for Truck Shipments from Eastern Reactors to an Eastern MRS Facility . . 5.4 
5.3 Summary of Estimated In-Transit Radiation Doses for Truck Shipments from Eastern Reactors to a Western MRS Facility . . . 5.4

5.4 Summary of Estimated In-Transit Radiation Doses for Truck Shipments from Western Reactors to the Repository . . . . . . 5.5

5.5 Summary of Estimated In-Transit Radiation Doses for Truck Shipments from Western Reactors to a Western MRS Facility . . . 5.5

5.6 Parameters/Algorithms Used to Calculate Routine Radiation Dose for Shipments via General Freight Rail . . . . . . . . . 5.10

5.7 Summary of Estimated In-Transit Radiation Doses for GFR Shipments from Eastern Reactors to an Eastern MRS Facility . . . 5.11

5.8 Summary of Estimated In-Transit Radiation Doses for GFR Shipments from Eastern Reactors to a Western MRS Facility . . 5.11

5.9 Summary of Estimated In-Transit Radiation Doses for GFR Shipments from Western Reactors to the Repository . . . . . . 5.12

5.10 Summary of Estimated In-Transit Radiation Doses for GFR Shipments from Eastern Reactors to an Eastern MRS Facility . . . 5.12

5.11 Time-Motion Analysis for Shipment by Dedicated Train from an Eastern MRS Facility to the Repository .......... . 5.16

5.12 Summary of Operational Characteristics of Postulated Dedicated Rail Shipment from the Eastern MRS Facility to the Repository

5.13 Time-Motion Analysis for Shipment by Dedicated Train from a Western MRS Facility to the Repository .......... . 5.17

5.14 Summary of Operational Characteristics of Postulated Dedicated Rail Shipment from the Western MRS Facility to the Repository .................. . 5.18

5.15 Summary of Estimated In-Transit Radiation Doses for Dedicated Train Shipments from an Eastern MRS Facility to the Repository - NFBC in Canisters

5.16 Summary of Estimated In-Transit Radiation Doses for Dedicated Train Shipments from an Eastern MRS Facility to the Repository - NFBC in Drums

5.17 Summary of Estimated In-Transit Radiation Doses for Dedicated Train Shipments from an Eastern MRS Facility to the Repository - No Fuel Consolidation 
5.18 Summary of Estimated In-Transit Radiation Doses for Dedicated Train Shipments from a Western MRS Facility to the Repository - NFBC in Canisters . . . . . . . . . . 5.20

5.19 Summary of Estimated In-Transit Radiation Doses for Dedicated Train Shipments from a Western MRS Facility to the Repository - NFBC in Drums . . . . . . . . . . . 5.21

5.20 Summary of Estimated In-Transit Radiation Doses for Dedicated Train Shipments from a Western MRS Facility to the Repository - No Fuel Consolidation . . . . . . . . . 5.21

5.21 Estimated Total Annual System Doses for In-Transit Operations in the Waste Management System with an MRS Facility . . . . . 5.26

6.1 Comparison of Estimated Cumulative Annual Radiation Doses in a Waste Management System With and Without an MRS Facility . 6.1 


\subsection{INTRODUCTION}

In the initial study (DOE 1987a) of the radiation doses received from operation of a postulated commercial spent fuel transportation system, the system consisted of the population of licensed nuclear power stations, the transportation system (truck and rail casks) for moving the spent fuel, and the cask receiving facilities at a deep geologic repository. While those initial studies were being performed, an additional facility was proposed for inclusion in the federal waste management system (FWMS). This additional facility is a monitored retrievable storage (MRS) facility (Parsons 1985; Woods et a1. 1988) which can store spent fuel until the repository is ready to begin accepting and emplacing operations, serve as a marshalling center for shipments to the repository, and may possibly consolidate the spent fuel assemblies into canisters prior to storage or shipment. The possible transportation links in the FWMS are illustrated in Figure 1.1. The additional radiation dose received by FWMS workers as a result of the cask handling, unloading, and loading operations introduced into the system by the addition of the MRS facility is evaluated in this current study.

Because of the possible variations in the functions of the MRS facility, and because the facility could be located either in the eastern or western portions of the United States, four distinct operational scenarios were defined and evaluated:

- an eastern MRS facility that receives, stores, and ships intact fuel assemblies to the western repository,

- an eastern MRS facility that receives, consolidates fuel assemblies, and canisters the consolidated rods and compacted non-fuel-bearing components (NFBC) prior to storage and/or shipment to the western repository,

- a western MRS facility that receives, stores, and ships intact fuel assemblies to the western repository, and

- a western MRS facility that receives, consolidates fuel assemblies, and canisters the consolidated rods and compacted NFBC prior to storage and/or shipment to the western repository. 
Eastern Reactors

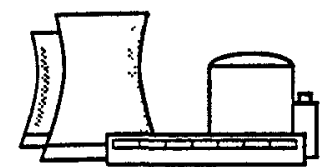

No-MRS System: Truck and

General Freight Rail Shipments

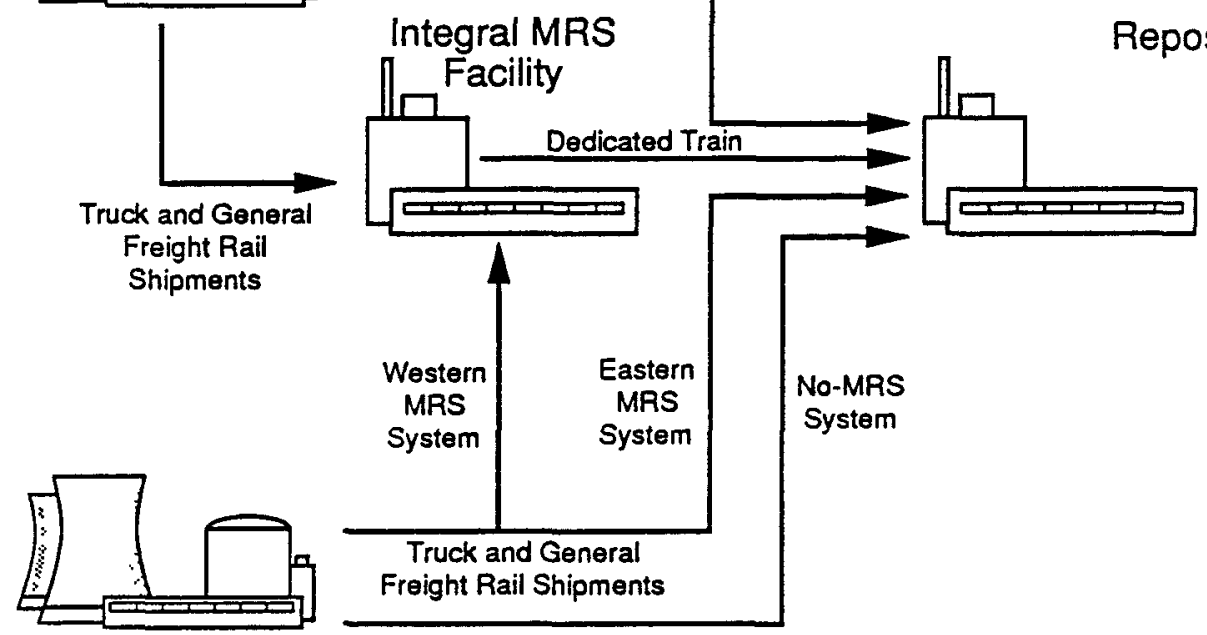

Repository

Western Reactors

FIGURE 1.1. Waste Management System Configurations Analyzed in This Study

The radiation doses from normal (non-accident) system operation calculated and estimated to be received by the workers at the reactors, the MRS facility, and the repository; by the workers in the transport area; and by the public for each of these scenarios are compared with the radiation doses received by similar groups for the reference No-MRS scenario (DOE 1987a).

A summary of the results of the total system analyses for the four MRSsystem scenarios and a comparison of those results with the results from the reference No-MRS scenario are presented in Section 2. The study bases and system assumptions for these analyses are presented in Section 3 . Section 4 contains the analyses of the shipping operations at the MRS facility and the receiving operations at the western repository that result in radiation dose to the facility workers. Section 5 contains the analyses of the in-transit activities that result in radiation dose to transport workers and to members 
of the public. The results of the analyses of the MRS system scenarios are compared with the results from the reference No-MRS system (DOE 1987a) in Section 6 . Section 7 lists the references cited in the report.

This addendum report extends the original study of the estimated radiation doses to the public and to workers resulting from transporting spent nuclear fuel from commercial nuclear power reactor stations through the federal waste management system (FWMS), to a system that contains a monitored retrievable storage (MRS) facility. The system concepts and designs utilized herein are consistent with those used in the original study (circa 1985-1987). Because the FWMS design is still evolving, the results of these analyses may no longer apply to the designs for casks and cask handling systems that are currently being considered. 


\subsection{SUMMARY}

The radiation doses received by workers in waste management system facilities, by workers in the transportation industry, and by members of the general public resulting from the transportation-related activities of the federal waste management system (FWMS) have been estimated for the situation when the system contains a monitored retrievable storage (MRS) facility. The estimated cumulative annual radiation doses to workers and to the public for the four scenarios containing an MRS facility are compared with annual radiation doses received by the same groups in the scenario without an MRS facility in the system (the reference No-MRS system) in Table 2.1 and in Figure 2.1, for a system throughput of 3000 MTU per year of spent fuel.

The dual results for facility workers in the consolidated fuel scenarios reflect the possible variation in the number of 150-ton casks containing nonfuel-bearing components (NFBC) from the consolidated assemblies that would be shipped from the MRS facility to the repository. This variation results from different assumptions about how much the NFBC is compacted and how the NFBC is packaged (in 9-in.-square canisters or in 55-gallon drums).

TABLE 2.1. Estimated Annual Radiation Doses to Facility Workers, Transportation Workers, and the General Public Resulting from Spent Fuel Transport

Operational

Scenario

Eastern MRS

Consol. Fue 1

Western MRS

Consol. Fue 1

Eastern MRS

Intact Fue?

Western MRS

Intact Fuel

No-MRS

Intact Fuel
Estimated Annual Radiation Dose (person-rem yr)

\begin{tabular}{lll}
\hline Facility & Transport & General \\
Workers & Workers & Public \\
\cline { 2 - 3 }
\end{tabular}

263

Totals

1010 to 1039

147

269

539

1834 to 1866

1087

149

264

1500

1113

270

540

1923

876

223

456

1555 


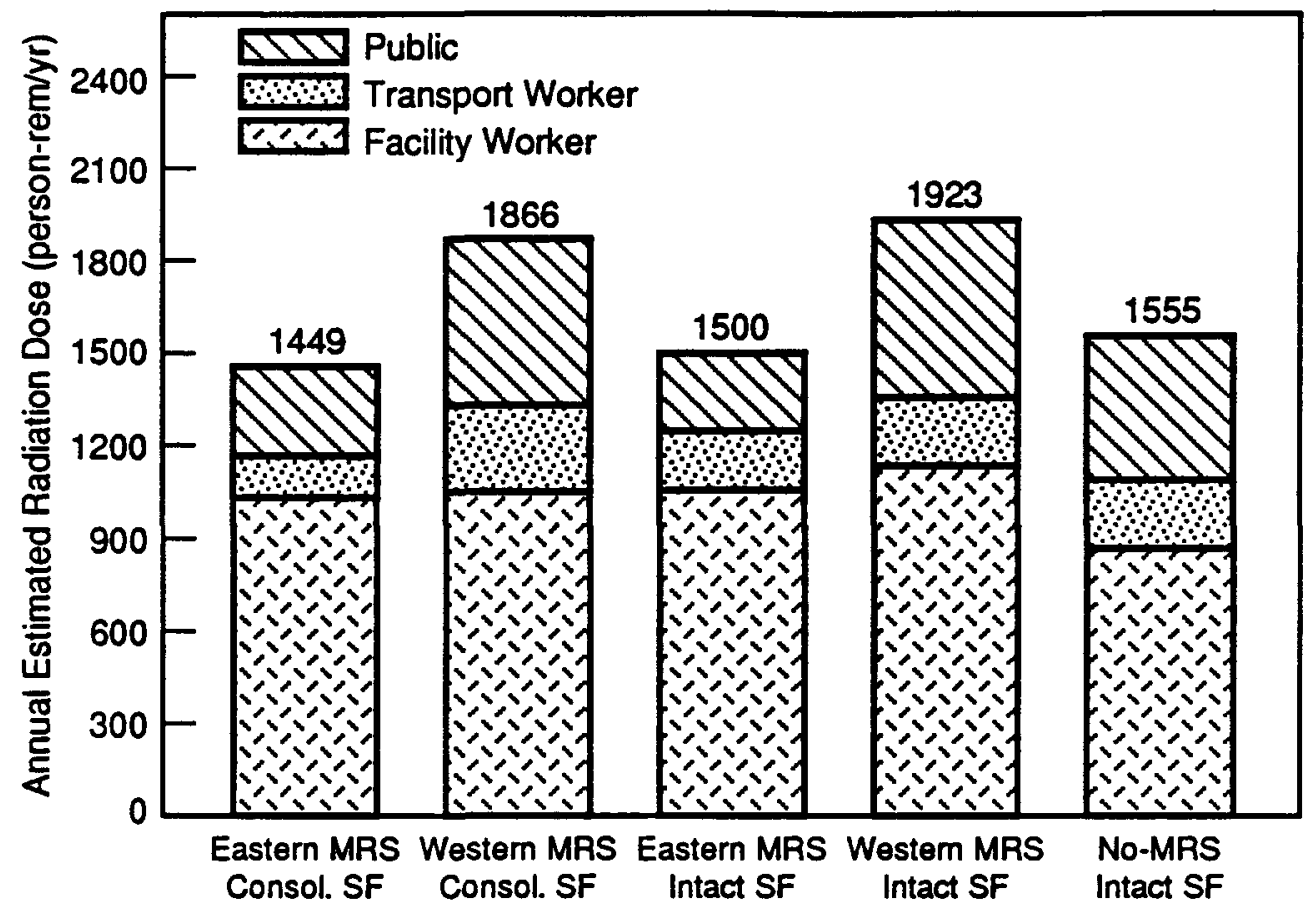

FIGURE 2.1. Distribution of Estimated Annual Dose by Recipient Category

From Table 2.1 it can be seen that utilizing an eastern MRS facility results in the least estimated radiation dose to transport workers and to the general public of all of the scenarios. The shorter transport distances between the reactors and the eastern MRS facility where the standard-capacity truck and rail casks are used, and the use of extra-large capacity casks and dedicated trains for the longer transport distance between the MRS facility and the repository, combine to result in lower doses to the transport workers and to the general public. On the other hand, including an MRS facility in the FWMS increases the radiation dose to the facility workers from about $15 \%$ to $27 \%$, due to the additional unloading and loading operations at the MRS facility. Consolidating the spent fuel at an MRS facility reduces the dose to the facility workers by about $5 \%$ to $8 \%$, compared with hand 7 ing the fuel intact. 
The average annual radiation doses received by the various categories of workers at the MRS and repository facilities are displayed in Table 2.2, for the western MRS facility/intact spent fuel scenario. Doses to workers at the repository are also displayed for the reference No-MRS scenario and for the eastern and western MRS scenarios, all with intact spent fuel. From the tabie it can be seen that if all of the workers in each category can be utilized in al1 locations for that category, thus distributing the total radiation dose evenly to all members of that category, the average annual doses are well below the 5 rem per year limit set by 10 CFR 20, with one exception. The maintenance-craftsmen are all utilized in the same activities and cannot be moved around to distribute the dose over a larger group. At worst, the average dose to a maintenance-craftsman is estimated to be over $19 \mathrm{rem} / \mathrm{yr}$, nearly four times greater than the NRC 1 imit and nearly 20 times the DOE target dose for MRS facility workers. At best, the doses to maintenance-craftsmen are estimated to be nearly 4 rem per year, exceeding the DOE target dose by almost a factor of 4 . Thus, it is obvious that major changes will be required in the

TABLE 2.2. Average Annual Radiation Doses to Facility Workers from $\underset{(r e m / y r)}{\text { Transportafion-Related Activities, by Worker Category }}$

\begin{tabular}{|c|c|c|c|c|}
\hline \multirow[b]{2}{*}{ Worker Category (number) } & \multirow{2}{*}{$\begin{array}{l}\text { Workers at } \\
\text { West. MRS (b) } \\
\end{array}$} & \multicolumn{3}{|c|}{ Workers at the Repository } \\
\hline & & No-MRS & E. MRS & W. MRS \\
\hline Radiation Monitor (10) & 1.75 & 0.81 & 0.28 & 0.16 \\
\hline Security Guard (8) & 1.11 & 1.00 & 0.35 & 0.17 \\
\hline Facility Operator (43) & 1.49 & 1.03 & 0.40 & 0.21 \\
\hline Maintenance-Craftsman (24) & 19.11 & 13.21 & 5.94 & 3.94 \\
\hline Quality Technician (12) & 0.96 & 0.42 & 0.14 & 0.08 \\
\hline Yard Engine Driver (4) & 0.80 & 0.61 & 0.21 & 0.11 \\
\hline Crane Operator (6) & 0.63 & 0.48 & 0.21 & 0.15 \\
\hline
\end{tabular}

(a) Intact fuel, $3000 \mathrm{MTU} / \mathrm{yr}$ system throughput.

(b) Worker dose at eastern MRS reduced by the ratio of throughputs $(2650 / 3000)$. 
cask handling activities at the FWMS facilities that utilize maintenancecraftsmen. The results shown for the No-MRS scenario were observed for the maintenance-craftsmen at the repository in the original Transportation ALARA study (DOE 1987a), and the additional activities associated with loading the 150 -ton casks at the MRS facility exacerbates the problem. 


\subsection{STUDY BASES AND SYSTEM ASSUMPTIONS}

With the exception of the additional activities associated with the inclusion of a monitored retrievable storage (MRS) facility into the federal waste management system (FWMS), the basic study bases and system assumptions are identical with those used in the initial study (DOE 1987a). For the convenience of the reader, those original assumptions and the additional assumptions related to the MRS facility are summarized in this section.

\subsection{AT-REACTOR ASSUMPTIONS}

A11 spent fuel is shipped as intact assemblies, in legal-weight truck casks or 100-ton rail casks, having capacities of 2 PWR/5 BWR and 14 PWR/36 BWR assemblies, respectively. Each cask is shipped as a single shipment, on a sole-use truck, or as general freight-rail (GFR).

Cask loading operations are identical with those presented in DOE (1987a), with the same radiation dose accumulated by the facility workers per cask shipment as was derived in the original study. Thus, for all scenarios, with and without an MRS facility, the dose to reactor workers resulting from shipping 3000 MTU of intact spent fuel assemblies was estimated to be about 437 person-mrem.

\subsection{IN-TRANSIT ASSUMPTIONS}

In the original study, there was only one in-transit scenario: single shipments from all reactors direct to the western repository (assumed to be located at Yucca Mountain, Nevada), using the casks defined above. In this addendum, there are four distinct variations of the in-transit scenario: 1) intact fuel assemblies or 2) consolidated fuel rods plus non-fuel-bearing components (NFBC) from the eastern MRS facility (assumed to be located near Oak Ridge, Tennessee); and 3) intact fuel assemblies or 4) consolidated fuel rods plus NFBC from the western MRS facility (assumed to be located at the Idaho National Engineering Laboratory).

The shipping distances and fractions of travel for representative truck shipments between reactors and the destination facilities were developed by 
averaging the data given in the repository and MRS environmental assessments (DOE 1986; DOE 1987b) except for shipments from reactors in the west to the western MRS facility. The latter approximation was based on shipments from the Trojan reactor in Oregon to the Yucca Mountain repository (DOE 1986). Shipping distances and travel fractions for shipments from the eastern and western MRS facilities to the repository were taken directly from the repository environmental assessment. The representative shipping distances and travel fractions used in this analysis are presented in Table 3.1.

Other bases and assumptions for truck and GFR shipments are the same as those given in DOE (1987a). These include shipment capacities, average speeds while moving, radiation dose rates emitted from the casks, exposure distances and times for various individuals, and numbers of individuals that are exposed at stops (e.g., state inspectors, bystanders).

TABLE 3.1. Shipping Distances and Travel Fractions for Each Transport Leg in the MRS System

\begin{tabular}{|c|c|c|c|c|c|c|}
\hline \multicolumn{2}{|c|}{ Transport Leq } & \multirow{2}{*}{$\begin{array}{l}\frac{\text { Transport }}{\text { Mode }} \\
\end{array}$} & \multirow{2}{*}{$\frac{\text { Shipping }}{\text { Distance, } \mathrm{km}}$} & \multicolumn{3}{|c|}{ Trave I Fraction (a) } \\
\hline Origin & Destination & & & Rural & Suburban & Urban \\
\hline $\begin{array}{l}\text { Eastern } \\
\text { Reactors }\end{array}$ & Eastern MRS & $\begin{array}{l}\text { Truck } \\
\text { Rail }\end{array}$ & $\begin{array}{l}1360 \\
1600\end{array}$ & $\begin{array}{l}\emptyset .61 \\
\emptyset .64\end{array}$ & $\begin{array}{l}0.38 \\
0.33\end{array}$ & $\begin{array}{l}0.01 \\
0.03\end{array}$ \\
\hline & Western MRS & $\begin{array}{l}\text { Truck } \\
\text { Rail }\end{array}$ & $\begin{array}{l}3360 \\
3336\end{array}$ & $\begin{array}{l}0.81 \\
0.80\end{array}$ & $\begin{array}{l}0.18 \\
0.19\end{array}$ & $\begin{array}{l}9.01 \\
0.01\end{array}$ \\
\hline $\begin{array}{l}\text { Western } \\
\text { Reactors }\end{array}$ & Western MRS ${ }^{(b)}$ & $\begin{array}{l}\text { Truck } \\
\text { Rai1 }\end{array}$ & $\begin{array}{l}2140 \\
2350\end{array}$ & $\begin{array}{l}\emptyset .82 \\
6.89\end{array}$ & $\begin{array}{l}0.18 \\
0.695 \\
(c)\end{array}$ & $\begin{array}{l}9.00 \\
0.015\end{array}$ \\
\hline & Tuff site & $\begin{array}{l}\text { Truck } \\
\text { Rai1 }\end{array}$ & $\begin{array}{l}1559 \\
1799\end{array}$ & $\begin{array}{l}9.83 \\
9.89\end{array}$ & $\begin{array}{l}0.16 \\
0.69\end{array}$ & $\begin{array}{l}6.01 \\
0.02\end{array}$ \\
\hline Eastern MRS & Yucca Mtn, site & Rail & 2350 & 9.86 & 9.12 & 0.82 \\
\hline Western MRS & Yucca Mtn, site & Rail & 1220 & 9.88 & 0.11 & 9.01 \\
\hline
\end{tabular}

(a) Given as fraction of total shipping distance through each population density region.

(b) Based on data in DOE (1986) for shipments from Trojan to the Yucca Mountain repository site.

(c) Travel fractions in DOE (1986) added to more than 1.0 because of round-off. An equal split between urban and suburban travel was assumed for this analysis. 
Dedicated trains are assumed to be used to transport spent fuel and nonfuel-bearing components (NFBC) wastes from the MRS facility to the repository. A dedicated train shipment is one in which the spent fuel and radioactive wastes from the MRS facility are the only cargo. The dedicated train shipments between the MRS facility and the repository consist of railcars carrying spent fuel casks, railcar casks carrying NFBC (when fuel consolidation is assumed), railcar casks containing high-activity wastes, and railcars carrying transuranic wastes (Cashwell et a1. 1986). The dedicated train shipment also includes a locomotive, intervening flatcars between each railcar cask, and a caboose. A total of $3000 \mathrm{MTU} / \mathrm{yr}$ of spent fuel and NFBC wastes are to be transported from a western MRS facility to the repository. A total of 2650 MTU/yr of spent fuel is transported from the eastern MRS facility to the repository. The cask and shipment capacities of the various truck, general freight rail, and dedicated train shipments are presented in Table 3.2.

TABLE 3.2. Capacities of Truck, General Freight Rail, and Dedicated Train Shipments

\begin{tabular}{|c|c|c|c|c|c|}
\hline \multirow[b]{2}{*}{ Transport Mode } & \multicolumn{2}{|c|}{$\begin{array}{c}\text { Cask Capacity, } \\
\text { assemblies }\end{array}$} & \multirow{2}{*}{$\begin{array}{l}\text { Casks per } \\
\text { Shipment }\end{array}$} & \multicolumn{2}{|c|}{$\begin{array}{l}\text { Shipment Capacity(a) } \\
\text { (MTU/cask) }\end{array}$} \\
\hline & $\overline{\text { PWR }}$ & BWR & & PWR & BWR \\
\hline Truck & 2 & 5 & 1 & 0.924 & 0.930 \\
\hline General Freight Rail & 14 & 36 & 1 & 6.47 & 6.70 \\
\hline $\begin{array}{l}\text { Dedicated Train } \\
\text { - Consolidated } \\
\text { - Unconsolidated }\end{array}$ & $\begin{array}{l}56 \\
28\end{array}$ & $\begin{array}{r}140 \\
61\end{array}$ & $\begin{array}{l}5^{(c)} \\
5^{(d)}\end{array}$ & $\begin{array}{r}129.36 \\
64.68\end{array}$ & $\begin{array}{r}136.20 \\
56.73\end{array}$ \\
\hline
\end{tabular}

(a) Based on 9.462 MTU/PWR assembly and $\emptyset .186$ MTU/BWR assembly.

(b) Shipping cask holds 28 canisters of consolidated fue 1. Each canister holds 2 PWR or 5 BWR assemblies.

(c) Dedicated train shipments also include 2 railcar casks containing highactivity wastes, 1 railcar cask containing low dose rate transuranic wastes, and either 2 or 3 railcar casks containing fuel assembly hardware, depending upon whether hardware is packaged in canisters or drums, respectively.

(d) Shipment also includes one railcar cask containing high-activity wastes. 
For the in-transit assumptions, information on the numbers and the types of shipments and the transport distances associated with those shipments to and from the various facilities is presented in the balance of this subsection.

- System shipments associated with an eastern MRS facility:

- 2650 MTU per year from eastern reactors to MRS facility, Truck (606 MTU PWR/188 MTU BWR), Rail (986 MTU PWR/870 MTU BWR), single cask shipments, average distance $1300 \mathrm{~km}$ by truck, $1600 \mathrm{~km}$ by rail.

- 350 MTU per year from western reactors direct to repository, Truck (165 MTU PWR/45 MTU BWR), Rai1 (140 MTU PWR/0 MTU BWR). Single cask shipments, average distance $1550 \mathrm{~km}$ by truck, $1700 \mathrm{~km}$ by rail.

- From-MRS cask capacities: 28 PWR/61 BWR intact assemblies, 56 PWR/140 BWR consolidated rods in 28 nine-inch square canisters, 28 canisters or 20 fifty-five gallon drums of NFBC.

- Dedicated train shipments from MRS to repository, 5 fuel casks per shipment plus casks of NFBC as appropriate, average distance $2350 \mathrm{~km}$ by rail.

- System shipments associated with a western MRS facility:

- 2650 MTU per year from eastern reactors to the MRS facility, Truck (606 MTU PWR/188 MTU BWR), Rail (986 MTU PWR/870 MTU BWR), single cask shipments, average distance $3300 \mathrm{~km}$ by truck, $3330 \mathrm{~km}$ by rail.

- 350 MTU per year from western reactors to the MRS facility, Truck (165 MTU PWR/45 MTU BWR), Rail (140 MTU PWR/0 MTU BWR), single cask shipments, average distance $2140 \mathrm{~km}$ by truck, $2350 \mathrm{~km}$ by rail.

- From-MRS rail cask capacities same as for the eastern MRS, average distance $1220 \mathrm{~km}$ by rail.

- Numbers of intact fuel shipments per year:

- Reactor to eastern MRS (858 truck casks, 282 rail casks)

- Reactor to western repository (227 truck casks, 22 rail casks)

- Reactor to western MRS (1085 truck casks, 304 rail casks) 
- Eastern MRS to repository (123 PWR/93 BWR 150-ton rail casks)

- Western MRS to repository (147 PWR/97 BWR 150-ton rail casks)

- Numbers of consolidated fuel shipments per year:

- Eastern MRS to repository (102 150-ton rail casks of fuel, 35 150-ton rail casks of NFBC in 9-in.-square canisters [10wer bound volume] or 65150 -ton rail casks of NFBC in 55-gallon drums [upper bound volume])

- Western MRS to repository (116 150-ton rail casks of fuel, 39 150-ton rail casks of NFBC in 9-in.-square canisters [10wer bound volume] or 72150 -ton rail casks of NFBC in 55-gallon drums [upper bound volume])

Other specific assumptions related to the in-transit activities are given in the appropriate $\mathrm{places}$ in Section 5 of this report.

\subsubsection{At-MRS Assumptions}

Cask receiving and unloading operations at the MRS facility are identical with the cask receiving and unloading operations that were examined for the repository in the original study (DOE 1987a) with one exception. In this analysis, the small incremental dose resulting from the operations at the Cask Maintenance Facility has been omitted for simplicity. Those doses were estimated in the original study, were found to be quite small, and are independent of which FUMS operational scenario was examined. At the MRS facility, the same staff utilized in cask receiving operations are also utilized in cask loading and shipping operations which take place in a different part of the facility.

For consolidated fuel packaging, it is assumed that the fuel rods are packaged in 9-in.-square canisters which contain rods from either 2 PWR or 5 BWR assemblies.

For NFBC from consolidation operations, it is assumed that the NFBC material is packaged in either 9-in.-square canisters (NFBC from either 8 PWR or 10.4 BWR assemblies per canister) or in 55-gallon drums (NFBC from either 7 PWR or 7 BWR assemblies per drum). These two assumptions span the range of current assumptions being made in other studies of the operation of the FWMS. 
Loading operations at the MRS facility for the 150-ton rail cask are essentially the reverse of the unloading operations for the 100-ton rail cask, except for additional QC staff time devoted to overseeing the cask loading operations.

\subsubsection{At-Repository Assumptions}

Cask receiving and unloading operations at the repository for the legal weight truck and 100-ton rail cask shipments are identical with the cask receiving and unloading operations that were examined in the original study (DOE 1987a). Changes resulting from the additional receipt of the 150-ton cask are: 1) the total number of casks received per year is less, and 2) a somewhat longer average time is required to remove the canisters/assemblies from the larger-capacity casks.

\subsubsection{Dose Rate Assumptions}

The radiation dose rates in the work areas and in the immediate vicinity of the casks are the same as those developed in Section 4.1.2.4 of DOE (1987a). For the casks, that means dose rates that are essentially at the Department of Transportation (DOT) regulatory limits. 


\subsection{RADIATION DOSE ESTIMATES FOR FACILITY OPERATIONS}

Estimates of the annual radiation doses to workers employed in the facilities of the federal waste management system (FWMS) were developed using the same detailed, step-by-step operational analysis utilized in the spreadsheets presented in Appendix C of DOE (1987a). The receiving operations at the MRS facility were identical with the operations evaluated for the repository in the earlier study, except for the possibility of two throughput rates, $2650 \mathrm{MTU} / \mathrm{yr}$ for the eastern MRS and $3000 \mathrm{MTU} / \mathrm{yr}$ for the western MRS. For the loading operations using the 150-ton rail cask at the MRS facility, the spreadsheets were modified to reflect lower doses during receiving/cask opening operations with an empty cask and higher doses during the cask closure/ decontamination/shipping operations with a loaded cask, and to reflect the longer times required to fill the larger-capacity casks. The quality assurance technicians also received longer exposures to the radiation fields around the loaded cask because of the additional observations required during the closure/decontamination/and shipping operations, compared with the observations required during the receiving/cask opening operations. The detailed spreadsheets developed for these analyses are presented in Appendix $A$ of this addendum. The radiation doses estimated to facility workers, both MRS and repository, are presented in this section.

\subsection{CASK RECEIVING, LOADING, AND SHIPPING OPERATIONS AT MRS}

The various activities necessary to receive, load, and ship a 150-ton rail cask at the MRS facility, and to receive and unload the same cask at the repository, are presented in Table 4.1, together with the radiation doses received by facility workers in the performance of those activities. It can be seen from the table that the activities that produce the largest doses are those associated with handling the loaded cask. Doses from handling the empty cask are relatively minor. Actual cask loading operations are carried on from within the hot cell. As a result, doses resulting from the placement of intact assemblies or canisters of consolidated spent fuel into the 150-ton cask are minimal. 
TABLE 4.1. Handling Activities and Associated Worker Radiation Doses for the 150-Ton Rail Cask at the MRS and Repository Facilities

\section{Activity}

1. Receive transport vehicle and loaded (unloaded) cask at the site. Monitor, inspect, unhook off-site drive unit, attach on-site drive unit.

2. Move cask/carrier to parking area and wait for washdown station. Hook up to carrier puller when ready.

3. Wash cask/carrier, open personnel barrier, monitor, inspect, and dry.

4. Move cask/carrier to receiving and handling area.

5. Prepare cask for removal from carrier.

6. Remove cask from carrier and place on cask cart.

7. Move cask/cart to handling room, close roll-up door.

8. Prepare cask for unloading (loading), position work platform, install contamination barrier adapter, remove outer lid, sample gas in cask cavity, loosen inner lid bolts, install lid lifting adapter).

9. Open siliding shielding door to the cask/hot cell port room, retract work platform, move cask/cart into the hot cell port room.

19. Mate the cask to the hot cell port, close shield door.

11. Remove hot cell port plugs, using cell 20-ton crane.

12. Remove inner lid bolts, inner lid, fuel assembly spacer.

13. Un load (load) spent fuel assemblies to (from) the hot cell lag storage.

14. Monitor and vacuum cask basket/cavity (for un loading).

15. Replace fuel assembly spacer, inner lid/bolts, port plugs.

16. Decouple cask from hot cell port, open shielding door.

17. Move cask/cart to handling room.

18. Install work platform, remove contamination barrier adapter, lid lifting adapter, close, monitor, and decontaminate cask, open roll-up door, retract platform.
Location

Gatehouse

Parking Area

Washdown Area

Receiving Bay

Receiving Bay

Receiving Bay

Handling Room

Handling Room

Cell Port Room

0.050

$\emptyset .033$

0.083

0.242

2.100

Hot $\mathrm{Ce} 11$

Hot Cell

Hot Cell

Handling Room

Handling Room

0.542

0.400

$\emptyset . \emptyset 08$

1.217

9.217

0.013

1.154

Hot Cell

242

$$
\text { NA }
$$

1.442

$\emptyset .425$

460.475
Cell Port Room

Est imated Dose per Activity

(person-mrem per cask)

Cask Empty Cask Loaded

$0.000 \quad 6.250$

1.400

11.900

0.092

64.025

4.333

0.425

350.092

$\emptyset .242$

2.100

Cask Loaded Cask Empty

$0.65 \emptyset$

0.400

0.400

0.925

0.000

1.650 


\begin{tabular}{|c|c|c|c|}
\hline \multirow[b]{2}{*}{ Activity } & \multirow[b]{2}{*}{ Location } & \multicolumn{2}{|c|}{$\begin{array}{l}\text { Est imated Dose per Act ivity } \\
\text { (person-mrem per cask) }\end{array}$} \\
\hline & & MRS & Repository \\
\hline 19. Move cask/cart to receiving bay area. & Receiving Bay & $\begin{array}{l}\text { Cask Loaded } \\
0.425\end{array}$ & $\begin{array}{c}\text { Cask Empty } \\
\emptyset . \emptyset \emptyset 8\end{array}$ \\
\hline 20. Place cask on transport carrier. & Receiving Bay & 4.083 & 0.175 \\
\hline $\begin{array}{l}\text { 21. Prepare cask for shipment, install tiedowns, impact } \\
1 \text { imiters, and close personnel barrier. }\end{array}$ & Receiving Bay & 98.225 & 1.608 \\
\hline $\begin{array}{l}\text { 22. Connect on-site drive unit, move cask/carrier to } \\
\text { inspection area, disconnect on-site drive unit. }\end{array}$ & Inspection Area & 0.796 & 0.033 \\
\hline $\begin{array}{l}\text { 23. Hook up off-site drive unit, move to gatehouse, perform } \\
\text { final monitoring and inspection of cask. }\end{array}$ & Gatehouse Area & 13.750 & $\emptyset .683$ \\
\hline $\begin{array}{l}\text { 24. Notify appropriate organizations of the shipment's } \\
\text { departure. }\end{array}$ & Facility office & $\emptyset .000$ & 0.000 \\
\hline & & 525.983 & 448.308 \\
\hline
\end{tabular}

The results of the analysis of the spreadsheet for worker category doses for 150-ton rail cask loading at the MRS facility are presented in Table 4.2. The doses to the various groups of workers (radiation monitors, security guards, facility operators, maintenance-craftsmen, quality assurance technicians, yard engine drivers, and crane operators) are shown for a single cask, for the many casks loaded with intact fuel assemblies and shipped during a single year from an eastern MRS, a western MRS, and from both of those locations when the spent fuel is consolidated at the MRS prior to shipment. The number of casks loaded and shipped when the fuel is consolidated is dependent upon the assumptions made about how the non-fuel-bearing components (NFBC) of the consolidated assemblies are compacted and packaged. For the NFBC canisters (9-in.-square canisters, $15 \mathrm{ft}$ long), hardware from 8 PWR or 10.4 BWR assemblies is assumed to be contained in a single canister. For the NFBC drums, hardware from 7 PWR or 7 BWR assemblies is assumed to be contained in a single 55-gallon drum. The volume of a canister and of a drum is nearly the same. The combination of the higher hardware loading fraction and the better cask loading efficiency of the canister, compared with the drum, results in 30 to 33 fewer casks to be shipped per year in the case of the NFBC canister. 
TABLE 4.2. Estimated Radiation Doses per Cask Loaded, and Annual Doses to MRS Facility Workers for Loading the 150-ton Cask

\begin{tabular}{|c|c|c|c|c|c|c|c|}
\hline \multirow{4}{*}{$\begin{array}{l}\text { Staff }{ }^{(a)} \\
\text { Position }\end{array}$} & \multirow{4}{*}{$\begin{array}{l}\text { Dose/Cask } \\
\text { (mrem) }\end{array}$} & \multicolumn{6}{|c|}{ Annual Dose to MRS Workers for Loading 150-ton Cask (person-mrem/ $\mathrm{yr}$ ) } \\
\hline & & \multicolumn{2}{|c|}{ Intact Fue ] } & \multicolumn{4}{|c|}{ Consolidated Fuel and Packaged NFBC } \\
\hline & & \multirow{2}{*}{$\begin{array}{c}\text { Eastern MRS } \\
(2650 \mathrm{MTU} / \mathrm{yr})\end{array}$} & \multirow{2}{*}{$\begin{array}{c}\text { Western MRS } \\
(3000 \mathrm{MTU} / \mathrm{yr})\end{array}$} & \multicolumn{2}{|c|}{ Eastern MRS (2650 MTU/yr) } & \multicolumn{2}{|c|}{ Western MRS (3006 MTU/yr) } \\
\hline & & & & NFBC Canisters & NFBC Drums & NFBC Canisters & NFBC Drums \\
\hline RMI (4) & 8.333 & 1.802 .6 & 2.032 .9 & $1,142.4$ & 1.394 .9 & 1.286 .4 & 1.561 .4 \\
\hline RM2 (6) & 30.471 & $6,591.5$ & $7,430.7$ & $4,177.3$ & $5,100.8$ & $4,704.1$ & 5.769 .4 \\
\hline SGI (4) & 9.833 & 180.2 & 203.1 & 114.2 & 139.4 & 128.6 & 156.1 \\
\hline SG2 (4) & 9.900 & 194.7 & 219.5 & 123.4 & 150.7 & 138.9 & 168.6 \\
\hline OP1 (4) & ๑.833 & 180.2 & 203.1 & 114.2 & 139.4 & 128.6 & 156.1 \\
\hline OP2 (3) & ø.133 & 28.8 & 32.4 & 18.2 & 22.3 & 20.5 & 24.9 \\
\hline OP3 (12) & 49.596 & $10,728.6$ & $12,694.5$ & $6,799.1$ & $8,302.4$ & $7,656.6$ & $9,292.8$ \\
\hline OP4 (24) & 1.917 & 414.7 & 467.5 & 262.8 & 320.9 & 295.9 & 359.2 \\
\hline MC1 (24) & 397.800 & $86,052.1$ & 97.087 .5 & 54.534 .4 & $66,591.7$ & $61,412.4$ & $74,535.8$ \\
\hline QC1 (6) & 23.608 & $5,106.9$ & 5.757 .0 & $3,236.4$ & 3.952 .6 & $3,644.6$ & $4,423.4$ \\
\hline QC2 (6) & 3.458 & 748.9 & 843.3 & 474.1 & 578.9 & 533.8 & 647.9 \\
\hline YD (4) & 2.492 & 539.1 & 607.7 & 341.6 & 417.2 & 384.7 & 466.9 \\
\hline $\operatorname{co}(6)$ & 3.108 & 672.3 & 757.9 & 426.1 & 520.3 & 479.8 & 582.3 \\
\hline Dose & 523.5 & 113.240 & 127,658 & 71.764 & 87.631 & 80,815 & 98,685 \\
\hline Casks/yr & & 216.32 & 243.86 & 137.99 & 167.40 & 154.38 & 187.37 \\
\hline & & 387 & & $\emptyset .562$ & & .633 & \\
\hline
\end{tabular}

(a) $R M 1, R M 2=$ Radiation Monitors, SG1, SG2 $=$ Security Guards, OP1, OP2, OP3, OP4 = Facility Operators, $M C 1=$ Ma intenance-Craftsmen, QC1, QC2 = Quality Technicians, YD = Yard Engine Driver, CO = Crane Operator. The numbers in parentheses are the numbers of workers in each category.

Because the dose to workers at the MRS for cask loading and shipping is proportional to the number of casks handled, consolidating the spent fuel assemblies at the MRS facility reduces the dose to facility workers, compared with handling intact fuel assemblies, by a factor of 1.3 to 1.6 , depending upon the NFBC packaging assumption. The dose received by the workers performing fuel consolidation is negligible because that activity is conducted in highlyshielded hot cells. The cumulative annual dose to workers at the MRS is larger when the facility is in a western location, due to the increased facility throughput ( $3000 \mathrm{MTU} / \mathrm{yr}$ vs. $2650 \mathrm{MTU} / \mathrm{yr}$ ). 
The radiation doses shown in Table 4.2 must be combined with the doses resulting from receiving the spent fuel from the reactors. The results from the upper bound scenario (western MRS, intact fuel) are summarized in Table 4.3. From this table it can be seen that the radiation dose due to the

TABLE 4.3. Estimated Annual Radiation Doses to Workers at the Western

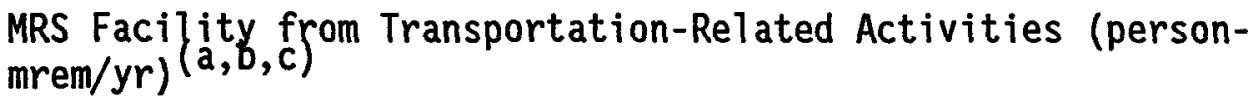

\begin{tabular}{|c|c|c|c|c|}
\hline $\begin{array}{l}\text { Staff (d) } \\
\text { Position }\end{array}$ & $\begin{array}{l}\text { Dose from }(e) \\
\text { Incoming } \\
\text { Truck \& Rail } \\
\end{array}$ & $\begin{array}{c}\text { Dose from } \\
\text { Outgoing } \\
150 \text {-ton Cask }\end{array}$ & $\begin{array}{c}\text { Total Dose } \\
\text { to MRS } \\
\text { Workers } \\
\end{array}$ & $\begin{array}{l}\text { Average } \\
\text { Dose per } \\
\text { Worker/yr }\end{array}$ \\
\hline RM1 (4) & $2,416.5$ & $2,032.9$ & $4,449.4$ & $1,112.4$ \\
\hline RM2 (6) & $5,597.1$ & $7,430.7$ & $13,027.8$ & $2,171.3$ \\
\hline$S G 1 \quad(4)$ & 195.1 & 203.1 & 398.2 & 99.6 \\
\hline$S G 2(4)$ & $8,253.1$ & 219.5 & $8,472.6$ & $2,118.2$ \\
\hline OP1 (4) & 195.1 & 203.1 & 398.2 & 99.6 \\
\hline OP2 (3) & $8,439.4$ & 32.4 & $8,471.8$ & $2,823.9$ \\
\hline OP3 (12) & $40,814.0$ & $12,094.5$ & $52,908.5$ & $4,409.0$ \\
\hline OP4 (24) & $1,692.0$ & 467.5 & $2,159.5$ & 90.0 \\
\hline MC1 (24) & $361,530.5$ & $97,007.5$ & $458,538.0$ & $19,105.8$ \\
\hline $\mathrm{QCl}(6)$ & $4,104.0$ & $5,757.0$ & $9,861.0$ & $1,643.5$ \\
\hline QC2 (6) & 833.9 & 843.3 & $1,677.2$ & 279.5 \\
\hline YD (4) & $2,572.5$ & 607.7 & $3,180.2$ & 795.1 \\
\hline \multirow[t]{2}{*}{$\cos (6)$} & $3,037.9$ & 757.9 & $3,795.8$ & 632.6 \\
\hline & 439,681 & 127,658 & 567,338 & \\
\hline
\end{tabular}
(a) Intact fuel, $3000 \mathrm{MTU} / \mathrm{yr}$ system throughput.
(b) Doses at western MRS with consolidated fuel are reduced by factors of 0.917 to 0.948 , depending upon NFBC packaging assumptions.
(c) Doses at eastern MRS are reduced from those at the western MRS by the ratio of the facility throughputs $(2650 / 3000=0.833)$.
(d) RM1, RM2 = Radiation Monitors, SG1, SG2 = Security Guards, OP1, OP2, OP3, OP4 = Facility Operators, MC1 = Maintenance-Craftsmen, QC1, QC2 = Quality Technicians, YD $=$ Yard Engine Driver, CO = Crane Opera- tor. The numbers in parentheses are the number of workers in each category.
(e) Data from DOE (1987a). 


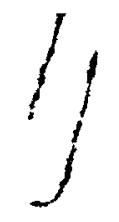

cask receiving and unloading operations (wherein a large number of truck casks and 100-ton rail casks are handled) comprises about $77 \%$ of the total dose to MRS workers. Less than $23 \%$ is attributable to the loading/shipping operations with the 150 -ton rail cask. This percentage is reduced to about $16 \%$ to $18 \%$ when the fuel is consolidated prior to shipment to the repository.

The average radiation dose to the various groups of workers in the facility is also shown, for the western MRS, intact fuel scenario. As was anticipated from the results of the original study (DOE 1987a), the average annual dose to several of the worker groups exceeds the DOE target dose ( $1 \mathrm{rem} / \mathrm{yr}$ ). The maintenance-craftsmen dose also exceeds the NRC's annual dose limit of $5 \mathrm{rem} / \mathrm{yr}$ for radiation workers.

\subsection{CASK RECEIVING OPERATIONS AT THE REPOSITORY}

With an MRS facility in the FWMS, the number of casks received annualiy at the repository is reduced significantly, from about 1,389 truck and rail casks (a11 containing intact fue1) to as few as 137150 -ton rail casks (eastern MRS containing consolidated fuel with NFBC in canisters). The estimated annual radiation doses to the various groups of workers at the facility are presented in Table 4.4 for the eastern and western MRS scenarios with intact fuel, together with the doses per LWT cask, 100-ton rail cask, and 150-ton rail cask. It can be seen that the dose to repository workers is 1 argest for the eastern MRS scenario, due to the larger (465 vs. 244) number of casks handled when 350 MTU of fuel is received directly from the reactors. Shipping consolidated fuel and packaged NFBC reduces the estimated dose by factors of 0.791 to 0.871 for the eastern MRS, and by factors of 0.633 to 0.768 for the western MRS, depending upon how the NFBC is packaged. 


\section{TABLE 4.4. Estimated Radiation Doses per Cask Unloaded and Annual Doses to Repository Workers for Unloading Casks Containing a Total of 3000 MTU per Year of Intact Spent Fuel (person-mrem/yr)}

Est imated Annual Radiation Dose to Repository Workers for Un loading Casks (person-mrem/yr)

\begin{tabular}{|c|c|c|c|c|c|c|c|}
\hline \multirow[b]{2}{*}{$\begin{array}{l}\text { Staff }(a) \\
\text { Position } \\
\end{array}$} & \multirow{2}{*}{$\begin{array}{l}\text { Dose per }{ }^{(b)} \\
\text { LWT Cask } \\
\text { (mrem) } \\
\end{array}$} & \multirow{2}{*}{$\begin{array}{l}\text { Dose per }{ }^{(b)} \\
100-t \text { Cask } \\
\text { (mrem) }\end{array}$} & \multirow{2}{*}{$\begin{array}{c}\text { Dose per } \\
150-t \text { Cask } \\
\text { (mrem) }\end{array}$} & \multicolumn{3}{|c|}{ Eastern MRS $(c)$} & \multirow{2}{*}{$\begin{array}{c}\frac{\text { Western MRS }}{\text { 150-t Rail }} \\
\text { (3060 MTU/yr) }\end{array}$} \\
\hline & & & & $\begin{array}{l}\text { LWT \& 100-t Rail } \\
(350 \mathrm{MTU} / \mathrm{yr}) \\
\end{array}$ & $\begin{array}{l}\text { 150-t Rail } \\
\text { (2650 MTU/yr) }\end{array}$ & $\begin{array}{l}\text { Repository } \\
\text { Tota } 1 \\
\end{array}$ & \\
\hline RM1 (4) & 1.550 & 2.417 & 2.417 & 404.1 & 522.8 & 926.9 & 589.4 \\
\hline RM2 (6) & 3.975 & 4.225 & 3.942 & 993.6 & 852.7 & $1,846.3$ & 961.3 \\
\hline SG1 (4) & 0.133 & 0.167 & 9.083 & 33.8 & 18.0 & 51.8 & 20.2 \\
\hline$S G 2(4)$ & 6.033 & 5.617 & 5.617 & $1,409.8$ & $1,215.1$ & $2,705.9$ & $1,369.8$ \\
\hline OP1 (4) & 0.133 & 0.167 & $\emptyset .683$ & 33.8 & 18.0 & 51.8 & 20.2 \\
\hline OP2 (3) & 5.892 & 6.733 & 6.733 & $1,482.9$ & 1.456 .5 & $2,939.4$ & $1,641.9$ \\
\hline OP3 (12) & 29.642 & 28.466 & 28.467 & $7,343.6$ & $6,158.9$ & $13,501.6$ & $6,942.0$ \\
\hline OP4 (24) & 0.850 & 1.517 & 2.350 & 242.7 & 508.4 & 751.1 & 573.1 \\
\hline $\operatorname{MC1}(24)$ & 220.300 & 403.000 & 388.000 & 58.720 .2 & $83,932.2$ & $142,652.4$ & $94,617.7$ \\
\hline $\mathrm{QC1}(6)$ & 2.960 & 2.850 & 2.850 & 726.4 & 616.5 & $1,342.9$ & 695.0 \\
\hline QC2 (6) & 0.460 & 0.808 & 1.175 & 127.6 & 254.2 & 381.8 & 286.5 \\
\hline YD (4) & 1.883 & 1.742 & 1.767 & 465.3 & 382.2 & 847.5 & 430.9 \\
\hline $\operatorname{CO}(6)$ & 1.775 & 3.658 & 3.658 & 482.0 & 791.3 & $1,273.3$ & 892.0 \\
\hline Dose & 274.7 & 462.2 & 447.1 & 72.546 .9 & 96.725 .8 & 169.272 .7 & 169.040 .1 \\
\hline Casks/yr & & & & $\begin{array}{l}226.69 \text { LWT } \\
21.64100-\mathrm{t}\end{array}$ & 216.32 & 464.86 & 243.86 \\
\hline \multicolumn{4}{|c|}{ Relative Dose } & & & 1.552 & 1.000 \\
\hline
\end{tabular}

(a) RM1, RM2 = Radiation Monitors, SG1, SG2 = Security Guards, OP1, OP2, OP3, OP4 = Facility 0perators, $M C 1=$ Ma intenance-Craftsmen, $Q C 1, Q C 2=$ Quality Technicians, $Y D=$ Yard Engine Driver, CO $=$ Crane Operator. The numbers in parentheses are the number of workers in each category.

(b) Data from DOE (1987a).

(c) Consolidated fuel scenarios reduce doses for the eastern MRS (intact fuel) shown above by factors of 0.791 to 0.871 for the eastern MRS and 0.633 to 0.768 for the western MRS. 


\subsection{ANALYSIS OF IN-TRANSIT OPERATIONS AND RADIATION DOSES}

Estimates of the unit (dose per-shipment and per-MTU) in-transit radiation doses to transport workers and to the general public resulting from truck and general freight rail (GFR) shipments from reactors and for the dedicated train shipments from the MRS facility are developed in this section. Also calculated are estimates of the cumulative annual dose to these groups resulting from transporting $3000 \mathrm{MTU} / \mathrm{yr}$ of spent fuel through the federal waste management system (FWMS). These doses are estimated for each of the system operational scenarios outlined in Section 3 of this report.

Section 5.1 contains the estimated doses from truck shipments, the estimated doses from GFR shipments are given in Section 5.2, and the estimated doses from dedicated train shipments are given in Section 5.3. Two MRS facility siting options are analyzed, an eastern site near Oak Ridge, Tennessee, and a western site at the Idaho National Engineering Laboratory. Reactors located in the eastern United States are assumed to transport their spent fuel to the MRS facility where it is consolidated and shipped to the repository. Reactors located in the western United States are assumed to transport their spent fuel directly to the repository. For the western MRS scenario, all reactors are assumed to ship their fuel to the MRS facility, and all of the fuel is moved from the MRS facility to the repository in the large 150-ton rail casks.

\subsection{ANALYSIS OF IN-TRANSIT TRANSPORT OPERATIONS AND DOSES}

(from-reactor truck shipments)

Electronic spreadsheets were developed to facilitate the calculation of from-reactor truck shipment doses. The spreadsheets utilize the relationships developed in DOE (1987a) to calculate the exposure times for and doses to the public and transport worker groups. A description of these computations is presented below.

\subsubsection{In-Transit Operations}

The first step in the analysis was to estimate the amount of time a truck shipment is moving and the amount of time spent at stops. The total trave 1 
time is estimated by dividing the total distances traveled in each population zone by the average speed in each zone and then summing over all three zones. The average travel speeds used in this analysis, which were taken from Appendix E of DOE (1987a), are $80 \mathrm{~km} / \mathrm{hr}$ (50 mph) in rural areas, $40 \mathrm{~km} / \mathrm{hr}$ (25 mph) in suburban areas, and $24 \mathrm{~km} / \mathrm{hr}(15 \mathrm{mph})$ in urban areas. The average stoptime per trip was calculated by multiplying the shipping distance by $0.011 \mathrm{hr}$ of stop-time per $\mathrm{km}$ of travel (DOE 1986). These stop-time and moving-time relationships were programmed into the spreadsheet. The total moving time and stop-time is calculated automatically by the spreadsheet using these average speeds and stop-time relationships and the distances traveled in each population zone (travel distances are input parameters).

The next steps were to program into the spreadsheet the relationship developed in DOE (1987a) to calculate the routine radiation doses. This relationship is of the following general form:

Per-Shipment Dose $=$ Dose Rate $\times$ Exposure Time $\times$ No. Of Exposed Persons

The parameters/algorithms used to evaluate this relationship are presented in Table 5.1 for each exposed population group for truck shipments.

\subsubsection{Collective Doses from Truck Shipments}

The results of the in-transit dose calculations for truck shipments are presented in this section. Routine doses are presented for truck drivers, escorts, service attendants, state inspectors, and the general public.

The spreadsheets for calculating the collective radiation doses from truck shipments are contained in Appendix C. Summaries of the results for the four truck shipments are presented in Tables 5.2 through 5.5. Table 5.2 is for shipments from eastern reactors to an eastern MRS facility, Table 5.3 is for truck shipments from eastern reactors to the western MRS facility, Table 5.4 is for truck shipments from western reactors to the repository, and Table 5.5 is for truck shipments from western reactors to a western MRS facility. These tables summarize the doses per shipment and per MTU, as well as annual doses to workers, the public, and the hypothetical maximally exposed individuat. 


\section{TABLE 5.1. Parameters/Algorithms Used to Calculate Routine Radiation Doses for Truck Shipments}

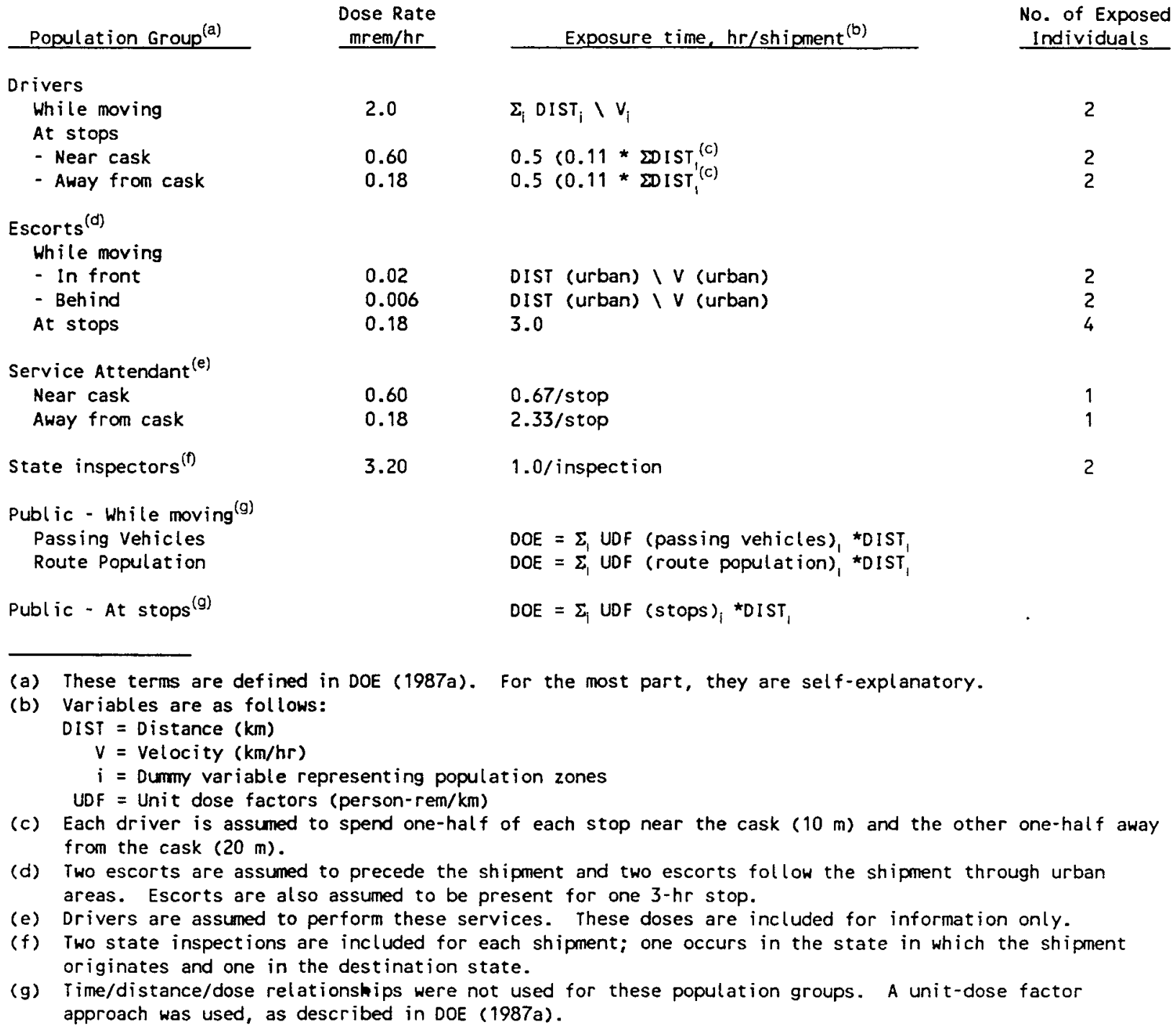



Shipments from Eastern Reactors to an Eastern MRS Facility

\section{Exposure Category \\ Transport Workers \\ - Drivers \\ - Escorts \\ - Attendants (c) \\ - Inspectors \\ Total Transport Workers}

Public

- While moving Passing Vehicles Route Population

- At stops

Total Public Dose ${ }^{(d)}$

\begin{tabular}{|c|c|c|}
\hline $\begin{array}{l}\text { Person- } \\
\text { mrem/shipment }\end{array}$ & $\begin{array}{l}\text { Person- } \\
\text { mrem/MTU (a) }\end{array}$ & $\begin{array}{l}\text { Person- } \\
\text { rem/yr }\end{array}$ \\
\hline
\end{tabular}

103.43

2.19

0.82

12.80

118.4

24.30

19.91

183.82

228.0

$\begin{array}{r}111.70 \\ 2.36 \\ 0.89 \\ 13.82 \\ \hline 127.9\end{array}$

$\begin{array}{r}88.69 \\ 1.88 \\ 0.70 \\ 10.98 \\ \hline 101.6\end{array}$

20.88

17.11

157.96

198.94

246.8
Doses to Maximally Exposed Individual (mrem/yr)

2586

118

88

685

NA

NA = Not Applicable

(a) Based on $0.924 \mathrm{MTU} /$ shipment (PWR fuel).

(b) Based on $794 \mathrm{MTU} / \mathrm{yr}$ : PWR/BWR fuel quantities are given in Section 3.

(c) Not included in totals. Truck refueling is typically performed by the orivers. If done by the service station attendant, the dose to drivers would be reduced.

(d) Assumes person becomes stuck in traffic next to a shipment one time per year.

TABLE 5.3. Summary of Estimated In-Transit Radiation Doses for Truck Shipments from Eastern Reactors to a Western MRS Facility

\begin{tabular}{|c|c|c|c|c|}
\hline Exposure Category & $\begin{array}{l}\text { Person- } \\
\text { mrem/shipment }\end{array}$ & $\begin{array}{l}\text { Person- } \\
\text { mrem/MTU }(a) \\
\end{array}$ & $\begin{array}{l}\text { Person }(\bar{b}) \\
\text { rem/yr }\end{array}$ & $\begin{array}{c}\text { Exposed Individua } \\
\text { (mrem/yr) }\end{array}$ \\
\hline \multicolumn{5}{|l|}{ Transport Workers } \\
\hline - Drivers & 227.34 & 246.04 & 195.06 & 2955 \\
\hline - Escorts & 2.23 & 2.41 & 1.91 & 122 \\
\hline - Attendants (c) & 2.46 & 2.67 & 2.11 & 88 \\
\hline - Inspector's & 12.80 & 13.85 & 10.98 & 688 \\
\hline Total Transport Workers & 242.4 & 262.3 & 208.0 & $\mathrm{NA}$ \\
\hline \multicolumn{5}{|l|}{$\begin{array}{l}\text { Public } \\
\text { - While moving }\end{array}$} \\
\hline Passing Vehicles & 36.90 & 39.94 & 31.71 & $1.6^{(d)}$ \\
\hline Route Population & 24.55 & 26.57 & 21.10 & 2.4 \\
\hline - At stops & 462.42 & 500.45 & 397.36 & 58.0 \\
\hline Total Public Dose ${ }^{(d)}$ & 523.9 & 567.0 & 450.2 & NA \\
\hline \multicolumn{5}{|c|}{$\begin{array}{l}\text { NA = Not Applicable } \\
\text { (a) Based on } 0.924 \mathrm{MTU} / \text { shipment (PWR fuel). } \\
\text { (b) Based on } 794 \mathrm{MTU} / \mathrm{yr} \text { : PWR/BWR fuel quantities are given in Section } 3 \text {. } \\
\text { (c) Not included in totals. Truck refueling is typically performed by the drivers. } \\
\text { service station attendant, the dose to drivers would be reduced. } \\
\text { (d) Assumes person becomes stuck in traffic next to a shipment one time per year. }\end{array}$} \\
\hline
\end{tabular}


TABLE 5.4. Summary of Estimated In-Transit Radiation Doses for Truck Shipments from Western Reactors to the Repository

\begin{tabular}{|c|c|c|c|c|}
\hline \multirow[b]{2}{*}{ Exposure Category } & \multicolumn{3}{|c|}{ Collective Doses } & \multirow{2}{*}{$\begin{array}{l}\text { Doses to Maximally } \\
\text { Exposed Individual } \\
\text { (mrem/yr) }\end{array}$} \\
\hline & $\begin{array}{c}\text { Person- } \\
\text { mrem/shipment }\end{array}$ & $\begin{array}{l}\text { Person- } \\
\text { mrem/MTU }\end{array}$ & $\begin{array}{l}\text { Person- } \\
\text { rem/yr }\end{array}$ & \\
\hline \multicolumn{5}{|l|}{ Transport Workers } \\
\hline - Drivers & 106.10 & 114.83 & 24.08 & 2546 \\
\hline - Escorts & 2.19 & 2.37 & 0.50 & 32 \\
\hline - Attendants $(c)$ & 1.64 & 1.78 & 0.37 & 23 \\
\hline - Inspectors & 12.80 & 13.85 & 2.91 & 182 \\
\hline Total Transport Workers & 121.1 & 131.1 & 27.5 & $\mathrm{NA}$ \\
\hline \multicolumn{5}{|l|}{ Public } \\
\hline $\begin{array}{l}\text { - While moving } \\
\text { Passing Vehicles }\end{array}$ & 16.3 & 17.6 & 3.7 & $16^{(d)}$ \\
\hline Route Population & 10.3 & 11.1 & 2.3 & 0.6 \\
\hline - At stops & 219.2 & 237.2 & 49.7 & 15 \\
\hline Total Public Dose ${ }^{(d)}$ & 245.8 & 265.9 & 55.7 & NA \\
\hline \multicolumn{5}{|c|}{$\begin{array}{l}\text { NA = Not Applicable } \\
\text { (a) Based on } 0.924 \mathrm{MTU} / \mathrm{sh} \text { pment (PWR fuel). } \\
\text { (b) Based on } 210 \mathrm{MTU} / \mathrm{yr} \text {; PWR/BWR fuel quantities are given in Section } 3 \text {. } \\
\text { (c) Not included in totals. Truck refueling is typicaliy performed by the drivers } \\
\text { service station attendant, the dose to drivers would be reduced. } \\
\text { (d) Assumes person becomes stuck in traffic next to a shipment one time per year }\end{array}$} \\
\hline
\end{tabular}

\section{TABLE 5.5. Summary of Estimated In-Transit Radiation Doses for Truck Shipments from Western Reactors to a Western MRS Facility}

\begin{tabular}{|c|c|c|c|c|}
\hline Exposure Category & $\begin{array}{c}\text { Person- } \\
\text { mrem/shipment }\end{array}$ & $\begin{array}{l}\text { Person- } \\
\text { mrem/MTU }\end{array}$ & $\begin{array}{l}\text { Person-- } \\
\mathrm{rem} / \mathrm{yr}(\overline{\mathrm{b}})\end{array}$ & $\begin{array}{c}\text { Exposed Individual } \\
\text { (mrem/yr) }\end{array}$ \\
\hline \multicolumn{5}{|l|}{ Transport Workers } \\
\hline - Orivers & 144.76 & 156.66 & 32.85 & 2750 \\
\hline - Escorts & 2.20 & 2.38 & 0.50 & 32 \\
\hline - Attendants $(c)$ & 1.64 & 178 & 037 & 23 \\
\hline - Inspectors & 12.80 & 13.85 & 291 & 182 \\
\hline Total Transport Workers & 159.8 & 1729 & 36.3 & NA \\
\hline \multicolumn{5}{|l|}{ Public } \\
\hline Passing Vehicles & 22.58 & 24.44 & 5.13 & $16^{(d)}$ \\
\hline Route Population & 14.99 & 16.22 & 3.41 & 06 \\
\hline - At stops & 297.08 & 321.52 & 67.52 & 15 \\
\hline Total Public Dose ${ }^{(d)}$ & 334.7 & 362.2 & 76.1 & NA \\
\hline \multicolumn{5}{|c|}{$\begin{array}{l}\text { NA = Not Appl icable } \\
\text { (a) Based on } 0.924 \mathrm{MTU} / \mathrm{sh} \text { pment (PWR fuel) } \\
\text { (b) Based on } 210 \mathrm{MTU} / \mathrm{yr} \text {; PWR/BWR fuel quant }\end{array}$} \\
\hline
\end{tabular}




\subsubsection{Maximally Exposed Individuals from Truck Shipments}

Estimates of the annual doses to maximally exposed individuals for the representative truck shipments are developed in this section. The approach to developing these estimates is, in general, to multiply individual per-shipment doses by the estimated number of shipments to which the maximaliy exposed individual is likely to be exposed. The results of these calculations are presented in Tables 5.3 through 5.6 for the representative truck shipments. In the following discussion, maximum individual exposures are the same for both MRS facility siting options because the annual shipment quantities from eastern reactors to the eastern MRS facility are the same as those from eastern reactors to the western MRS facility. Similarly, the shipment quantities from the western reactors to the western MRS facility are the same as for shipments from western reactors to the repository. Only the final destinations and, therefore, the shipping distances and travel fractions are different.

The per-shipment doses to the truck crews were calculated by adding together the collective doses at stops and while moving and then dividing the result by two persons (see Table 5.2). This approach resulted in individual truck driver doses of about 52, 114, 53, $73 \mathrm{rem} / \mathrm{shipment}$ for the four representative truck shipment routes, respectively. Based on the one-way transit times calculated within the spreadsheets using the formulas given in Table 5.1 and an estimated 32-hr waiting time at reactors (DOE 1987a), the total duration of each shipment is estimated at about 106, 210, 112, $142 \mathrm{hr}$ for the four representative truck shipment routes, respectively. Assuming each driver is available for $5400 \mathrm{hr} / \mathrm{yr}$ (DOE 1987a), each two-person driving team can move approximately $50,26,48$, and 38 shipments/yr, respectively, over the four routes. A formula for estimating the total annual shipments for truck drivers is programmed into the spreadsheet, as shown below:

Total Annual = Shipments
(Hours available per year) (Waiting time plus travel time per round-trip shipment) 
The number of hours available per year is taken to be $5,400 \mathrm{hr}$ (DOE 1987a). Thus, the estimated total annual individual doses are approximately 2590 , 2960,2550 , and $2750 \mathrm{rem} / \mathrm{yr}$ for the representative truck shipment routes, respectively.

An attendant at a service station where refueling is performed by an attendant would receive approximately $0.83 \mathrm{rem} / \mathrm{sh}$ ipment (DOE 1987a). It is assumed that the maximally exposed attendants are at the last truck stop before the MRS facility or repository. It is also assumed that this truck stop is used by $1 / 2$ of the total shipments (total annual shipments were estimated at 858 and 227 shipments/yr from eastern and western reactors, respective1y), and that the truck stop operates on a 4-shift basis, 24 hours/ days, 7 days per week, with the maximally exposed service attendant exposed to 107 and 28 shipments/yr, respectively. The resulting exposures to the maximally exposed service attendants are therefore about $88 \mathrm{rem} / \mathrm{yr}$ and $23 \mathrm{rem} / \mathrm{yr}$, respectively.

Doses to individual state inspectors were estimated in DOE (1987a) at $3.2 \mathrm{rem} /$ inspection. It is conservatively assumed that the maximally exposed inspectors are at the last state border before the MRS facility and repository and that this inspection station is used by all 858 shipments/yr from eastern reactors or all 227 shipments/yr from western reactors. Assuming that there are four inspectors that share the inspections equally, each inspector would be exposed to 214 shipments/yr from eastern reactors and 57 shipments/yr from western reactors. The estimated annual doses to the maximally exposed inspectors then become about 688 and $182 \mathrm{rem} / \mathrm{yr}$, respectively.

The doses to the maximally exposed escorts were calculated under the same assumptions that were used in DOE (1987a). The dose was estimated assuming the escort is present for a single entire stop at a distance of 20 meters from the cask and precedes the cask by 50 meters in an urban area. This resulted in a per-shipment dose of 0.56 rem per escort. Assuming that each of the shipments is escorted by one of four escort teams, each escort could be exposed to 214 shipments/yr from eastern reactors and 57 shipments/yr from western reactors. The resulting estimated annual doses to the maximally exposed escorts are about $120 \mathrm{rem} / \mathrm{yr}$ and $32 \mathrm{rem} / \mathrm{yr}$, respectively. 
The maximum annual individual dose for a member of the public (nontransport worker at truck stops) was estimated using the dose rate at $20 \mathrm{~m}$ from the side of the cask $(0.18 \mathrm{rem} / \mathrm{hr})$ and an assumed exposure time of 3 hours/shipment. This results in an individual dose of $0.54 \mathrm{rem} / \mathrm{shipment.}$ Assuming the truck stop operates on a 4 shift, 24 hours/day, 7 day/week basis and that this truck stop services $1 / 2$ of the shipments, this individual could be exposed to 107 shipments/yr from eastern reactors or 28 shipments/yr from western reactors. The estimated doses to the maximally exposed members of the public at truck stops are therefore about $58 \mathrm{rem} / \mathrm{yr}$ and $15 \mathrm{rem} / \mathrm{yr}$, respectively.

The maximum annual individual dose to a member of the public that resides near a truck route was estimated using the data given in DOE (1986, p. A-19). This document indicates that a person $30 \mathrm{~m}$ from a passing truck shipment receives approximately $0.00283 \mathrm{rem} / \mathrm{shipment.} \mathrm{Assuming} \mathrm{this} \mathrm{individ-}$ ual is present for the passage of al1 858 shipments/yr from eastern reactors and 227 shipments/yr from western reactors, the estimated annual doses to the maximally exposed members of the public are estimated to be about $2.4 \mathrm{rem} / \mathrm{year}$ and $0.6 \mathrm{rem} /$ year, respectively.

\subsection{ANALYSIS OF IN-TRANSIT TRANSPORT OPERATIONS AND DOSES \\ (from-reactor rail shipments)}

The analysis of in-transit routine doses for GFR shipments from reactors is presented in this section. The representative shipment origin-destination pairs evaluated in this section are the same as those evaluated in the previous section for truck shipments (i.e., eastern reactors ship to an eastern MRS facility, eastern reactors ship to a western MRS facility, western reactors ship to the repository, and western reactors ship to the western MRS facility.

\subsubsection{In-Transit Operations}

The shipping distances and travel fractions given in Table 3.1 were used to develop estimates of the exposure times for the various population groups exposed to the GFR shipments. As with truck operations, average moving- and stop-times for the GFR shipments were programmed into a 
spreadsheet. The average travel speeds used while moving were $32 \mathrm{~km} / \mathrm{hr}$ (20 $\mathrm{mph}$ ) in all three population zones (Wooden 1986). The average stop-time per trip was calculated using the following relationship (Ostmeyer 1986):

$$
\text { Stop-time } / \text { trip }=60+0.033 * \text { DIST }
$$

where DIST = One-way shipping distance $(\mathrm{km})$, and Stop-time is given in hours.

Similar to the dose calculations for truck shipments, electronic spreadsheets were developed to calculate routine doses from GFR shipments. The relationship between radiation doses and exposure times, dose rates, and numbers of exposed individuals that were developed in DOE (1987a) was utilized in the spreadsheets. The parameters/algorithms used to evaluate this relationship are presented in Table 5.6.

\subsubsection{Collective Doses from General Freight Rail Shipments}

Estimates of the collective radiation doses for the representative GFR shipments are presented in this section. The doses are received by train crew members, employees at railyards, state inspectors, escorts, and the general public residing near the rail route and railyards.

The spreadsheets for calculating the cumulative radiation doses for GFR rail shipment are contained in Appendix $C$. Summaries of the doses for the four representative rail shipments are presented in Tables 5.7 through 5.10 . Table 5.7 contains a summary of the doses for the representative rail shipment from eastern reactors to an eastern MRS facility site. Table 5.8 contains similar information for the representative rail shipment from eastern reactors to the western MRS facility. Table 5.9 contains similar information for the representative rail shipment from western reactors to the repository, and Table 5.10 contains this information for shipments from western reactors to the western MRS facility. The tables summarize the estimated dose pershipment and per-MTU, the total annual collective doses, and the doses to maximally-exposed individuals. 
TABLE 5.6. Parameters/Algorithms Used to Calculate Routine Radiation Doses for Shipments via General Freight Rail (GFR)

\begin{tabular}{|c|c|c|c|}
\hline Population Group ${ }^{(a)}$ & $\begin{array}{l}\text { Dose Rate } \\
\text { mrem/hr }\end{array}$ & Exposure time, $h r /$ shipment $^{(b)}$ & $\begin{array}{l}\text { No. of Exposed } \\
\text { Individuals }\end{array}$ \\
\hline $\begin{array}{l}\text { Train/Rajl road Crews } \\
\text { While moving } \\
\text { At stops }\end{array}$ & 0.0021 & DIST $\backslash V$ & 5 \\
\hline $\begin{array}{l}\text { - Crew } \\
\text { - Handlers } \\
\text { - Yard crew }\end{array}$ & $\begin{array}{l}0.0021 \\
0.76 \\
0.0013\end{array}$ & $\begin{array}{l}60+(0.033 * \text { DIST }) \\
0.2 *(\text { No. of stops })(c) \\
60+(0.033 * \text { DIST })\end{array}$ & $\begin{array}{r}5 \\
10 \\
100\end{array}$ \\
\hline $\begin{array}{l}\text { Escorts }^{(d)} \\
\text { While moving } \\
\text { At stops }\end{array}$ & $\begin{array}{l}0.06 \\
0.06\end{array}$ & $\begin{array}{l}\text { DIST \V } \\
60+(0.033 * \text { DIST })\end{array}$ & $\begin{array}{l}2 \\
2\end{array}$ \\
\hline State inspectors ${ }^{(e)}$ & 0.76 & $0.5 /$ inspection & 2 \\
\hline $\begin{array}{l}\text { Public - While moving } \\
\text { Passing Vehicles } \\
\text { Route Population }\end{array}$ & & $\begin{array}{l}\text { DOE }=\Sigma_{i} \text { UDF (passing vehicles) }{ }_{i}{ }^{*} \text { DIST }_{i} \\
\text { DOE }=\Sigma_{i} \text { UDF (route population) }{ }^{*} \text { DIST }_{i}\end{array}$ & \\
\hline Public - At stops & 0.00055 & $60+(0.033 *$ DIST $)$ & 300 \\
\hline
\end{tabular}

(a) These terms are defined in DOE (1987a). For the most part, they are self-explanatory.

(b) Variables are as follows:

DIST $=$ Distance $(\mathrm{km})$

$V=$ Velocity $(\mathrm{km} / \mathrm{hr})$

$\mathrm{i}=$ Durmy variable representing population zones

UDF = Unit dose factors (person-rem/km)

(c) No. of stops $=2+(0.0018 \star$ DIST); Ostmeyer (1986).

(d) Two escorts are assumed to accompany the GFR shipment at all times.

(e) Shipments are inspected by two-person inspection teams in the state in which the shipment originates and in the destination state.

(f) Time/distance/dose relationships were not used for these population groups. A unit-dose factor approach was used, as described in DOE (1987a).

\subsubsection{Maximally Exposed Individuals from General Freight Rail Shipments}

Estimates of the annual doses to maximally exposed individuals for the representative rail shipments are developed in this section. The approach to developing these estimates is similar to that described for truck shipments. The results of these calculations were presented in Tables 5.7 through 5.10 for the four representative rail shipments addressed. As with the maximally exposed individuals for the representative truck shipments, the number of shipments from eastern reactors and from western reactors that an individual is exposed to is the same for both MRS facility siting options. 
IABLE 5.7. Summary of Estimated In-Transit Radiation Doses for GFR Shipments from Eastern Reactors to an Eastern MRS Facility

\begin{tabular}{|c|c|c|c|c|}
\hline \multirow[b]{2}{*}{ Exposure Category } & \multicolumn{3}{|c|}{ Collective Doses } & \multirow{2}{*}{$\begin{array}{l}\text { Doses to Maximally } \\
\text { Exposed Individual } \\
\text { (mrem/yr) }\end{array}$} \\
\hline & $\begin{array}{c}\text { Person- } \\
\text { mrem/shipment }\end{array}$ & $\begin{array}{l}\text { Person- } \\
\text { mrem/MTU }(\mathrm{a})\end{array}$ & $\begin{array}{l}\text { Person-̄ } \\
\text { rem/yr (b) }\end{array}$ & \\
\hline \multicolumn{5}{|l|}{ Transport Workers } \\
\hline Train crew & 1.71 & 0.26 & 0.48 & 1.8 \\
\hline Handlers & 7.41 & 1.15 & 2.09 & 10.7 \\
\hline Yard crew & 14.66 & 2.27 & 4.14 & 1.1 \\
\hline Escorts & 19.52 & 3.02 & 5.51 & 102 \\
\hline Inspectors & 1.52 & 0.23 & 0.43 & 27 \\
\hline Total Transport Workers & 44.8 & 6.9 & 12.7 & NA \\
\hline \multicolumn{5}{|l|}{$\begin{array}{l}\text { Public } \\
\text { - While moving }\end{array}$} \\
\hline Passing Vehicles & 0.34 & 0.05 & 0.10 & NA \\
\hline Route Population & 17.36 & 2.68 & 4.98 & 1.4 \\
\hline - At stops & 14.88 & 2.30 & 4.27 & 3.1 \\
\hline Total Public Dose & 32.6 & 5.0 & 9.4 & NA \\
\hline
\end{tabular}

NA $=$ Not Applicable

(a) Based on 6.47 MTU/shipment (PWR fuel).

(b) Based on 1856 MTU/hr: PWR/BWR shipment quantities are given in Section 3.

TABLE 5.8. Summary of Estimated In-Transit Radiation Doses for GFR Shipments from Eastern Reactors to a Western MRS Facility

\begin{tabular}{|c|c|c|c|c|}
\hline \multirow[b]{2}{*}{ Exposure Category } & \multicolumn{3}{|c|}{ Collective Doses } & \multirow{2}{*}{$\begin{array}{l}\text { Doses to Maximall } \\
\text { Exposed Individua } \\
\text { (mrem/yr) }\end{array}$} \\
\hline & $\begin{array}{c}\text { Person- } \\
\text { mrem/shipment }\end{array}$ & $\begin{array}{l}\text { Person- } \\
\text { mrem/MTU }(a)\end{array}$ & $\begin{array}{l}\text { Person } \\
\text { rem/yr }\end{array}$ & \\
\hline \multicolumn{5}{|l|}{ Transport Workers } \\
\hline Train crew & 2.87 & 0.44 & 0.81 & 1.8 \\
\hline Handlers & 12.13 & 1.88 & 3.42 & 10.7 \\
\hline Yard crew & 22.06 & 3.41 & 6.23 & 1.1 \\
\hline Escorts & 32.82 & 5.07 & 9.26 & 102 \\
\hline Inspectors & 1.52 & 0.23 & 0.43 & 27 \\
\hline Total Transport Workers & 71.4 & 11.0 & 20.2 & NA \\
\hline \multicolumn{5}{|l|}{$\begin{array}{l}\text { Public } \\
\text { - While moving }\end{array}$} \\
\hline Passing Vehicles & 0.45 & 0.07 & 0.13 & NA \\
\hline Route Population & 20.86 & 3.22 & 5.98 & 1.4 \\
\hline - At stops & 22.39 & 3.46 & 6.42 & 3.1 \\
\hline Total Public Dose & 43.7 & 6.8 & 12.5 & NA \\
\hline
\end{tabular}


TABLE 5.9. Summary of Estimated In-Transit Radiation Doses for GFR Shipments from Western Reactors to the Repository

\begin{tabular}{|c|c|c|c|c|}
\hline \multirow[b]{2}{*}{ Exposure Category } & \multicolumn{3}{|c|}{ Collective Doses } & \multirow{2}{*}{$\begin{array}{l}\text { Doses to Maximall } \\
\text { Exposed Individua } \\
\text { (mrem/yr) }\end{array}$} \\
\hline & $\begin{array}{c}\text { Person- } \\
\text { mrem/shipment }\end{array}$ & $\begin{array}{l}\text { Person- } \\
\text { mrem/MTU }\end{array}$ & $\begin{array}{l}\text { Person- } \\
\mathrm{rem} / \mathrm{yr}\end{array}$ & \\
\hline \multicolumn{5}{|l|}{ Transport Workers } \\
\hline Train crew & 1.77 & 0.27 & 0.04 & 0.14 \\
\hline Handlers & 7.67 & 1.19 & 0.17 & 0.8 \\
\hline Yard crew & 15.07 & 2.33 & 0.33 & 0.1 \\
\hline Escorts & 20.26 & 3.13 & 0.44 & 7.9 \\
\hline Inspectors & 1.52 & 0.23 & 0.03 & 2.1 \\
\hline Total Transport Workers & 46.3 & 7.2 & 1.0 & NA \\
\hline \multicolumn{5}{|l|}{$\begin{array}{l}\text { Public } \\
\text { - While moving }\end{array}$} \\
\hline Passing Vehicles & 0.17 & 0.03 & 0.004 & NA \\
\hline Route Population & 5.29 & 0.82 & 0.11 & 0.1 \\
\hline - At stops & 15.30 & 2.36 & 0.33 & 0.2 \\
\hline Total Public Dose & 20.8 & 3.2 & 0.4 & NA \\
\hline
\end{tabular}

NA $=$ Not Applicable

(a) Based on 6.47 MTU/shipment (PWR fuel).

(b) Based on $140 \mathrm{MTU} / \mathrm{hr}$; PWR/BWR shipment quantities are given in Section 3.

TABLE 5.10. Summary of Estimated In-Transit Radiation Doses for GFR Shipments from Eastern Reactors to an Eastern MRS Facility

\begin{tabular}{|c|c|c|c|c|}
\hline \multirow[b]{2}{*}{ Exposure Category } & \multicolumn{3}{|c|}{ Collective Doses } & \multirow{2}{*}{$\begin{array}{l}\text { Doses to Maximally } \\
\text { Exposed Individual } \\
\text { (mrem } / y r)\end{array}$} \\
\hline & $\begin{array}{c}\text { Person- } \\
\text { mrem/shioment }\end{array}$ & $\begin{array}{l}\text { Person- } \\
\text { mrem/MTU }(a)\end{array}$ & $\begin{array}{l}\text { Person- } \\
\mathrm{rem} / \mathrm{yr}\end{array}$ & \\
\hline \multicolumn{5}{|l|}{ Transport Workers } \\
\hline Train crew & 2.22 & 0.34 & 0.05 & 0.14 \\
\hline Handlers & 9.47 & 1.46 & 0.20 & 0.8 \\
\hline Yard crew & 17.88 & 2.76 & 0.39 & 0.1 \\
\hline Escorts & 25.32 & 3.91 & 0.55 & 7.9 \\
\hline Inspectors & 1.52 & 0.23 & 0.03 & 2.1 \\
\hline Total Transport Workers & 56.4 & 8.7 & 1.2 & NA \\
\hline \multicolumn{5}{|l|}{$\begin{array}{l}\text { Public } \\
\text { - While moving }\end{array}$} \\
\hline Passing Vehicles & 0.23 & 0.04 & 0.005 & NA \\
\hline Route Population & 7.74 & 1.20 & 0.17 & 0.1 \\
\hline - At stops & 18.16 & 2.81 & 0.39 & 0.2 \\
\hline Total Public Dose & 26.1 & 4.0 & 0.6 & NA \\
\hline
\end{tabular}


The annual dose to individual train crew members was estimated using a per-shipment dose of $0.025 \mathrm{rem} / \mathrm{shipment}$ (DOE 1987a). Assuming that the railyard nearest to the MRS facility or repository will deliver all 282 shipments/yr from eastern reactors and 22 shipments/yr from western reactors, and assuming a four-shift, 24 hours/day, 7 days/week operation, each crew member is estimated to deliver about 70 and 6 shipments/yr, respectively. The annual doses to the maximally exposed crew members are estimated to be about 1.8 $\mathrm{rem} / \mathrm{yr}$ and $0.1 \mathrm{rem} / \mathrm{yr}$, respectively.

Radiation doses to individual state inspectors were estimated in DOE (1987a) to be $0.4 \mathrm{rem} /$ inspection. Assuming 70 shipment/yr from eastern reactors and 6 shipments/yr from western reactors, the annual doses to the maximally exposed inspectors are estimated to be about $27 \mathrm{rem} / \mathrm{yr}$ and $2 \mathrm{rem} / \mathrm{yr}$, respectively.

The radiation dose to individual train handlers was estimated in DOE (1987a) to be $0.15 \mathrm{rem} / \mathrm{shipment.} \mathrm{Assuming} \mathrm{the} \mathrm{nearest} \mathrm{railyards} \mathrm{to} \mathrm{the} \mathrm{desti-}$ nation facilities handle all shipments and that the railyards are operated on a 4 shift/day basis, each train handler would be exposed to 70 shipments/yr from eastern reactors to the MRS facility or 6 shipments/yr from western reactors to the repository. Therefore, the estimated annual doses to the maximally exposed train handlers are estimated to be about $11 \mathrm{rem} / \mathrm{yr}$ and I $\mathrm{rem} / \mathrm{yr}$, respectively.

The maximum annual individual dose to a member of the public residing near a rail route was estimated using data given in DOE 1986 ( $p . A-19)$. This document states that a person $30 \mathrm{~m}$ from a rail route receives approximately 0.00504 rem per shipment. Assuming these persons are present while all 282 shipments/yr from eastern reactors pass by or al1 22 shipments/yr from western reactors pass by, the annual doses to the maximally exposed member of the public residing near the rail route are about $1.4 \mathrm{rem} / \mathrm{yr}$ and $0.1 \mathrm{rem} / \mathrm{yr}$, respectively.

The maximum annual dose to a public resident who resides near a railyard was estimated assuming an exposure distance for $300 \mathrm{~m}$ from the side of the cask (the dose rate at this distance is calculated to be $0.00055 \mathrm{rem} / \mathrm{hr}$ based on calculations presented in DOE 1987a) and that this individual is present 
for the entire $20 \mathrm{hr} / \mathrm{stop}$. It was also assumed that the railyard is the last stop before the final destinations so that a11 282 shipments/yr destined for the MRS facility or all 22 shipments/yr destined for the repository stop at this railyard. The annual exposures to the maximally exposed members of the public residing near a railyard are estimated to be about 3.1 and $0.2 \mathrm{rem} / \mathrm{yr}$, respectively.

The maximum annual dose to train escorts was estimated assuming the maximally exposed escort accompanies the shipments from the last railyard to the MRS facility or repository. The exposure time is thus approximately $6 \mathrm{hr}$ for both destination facilities. In DOE (1987a), the per-shipment dose to these individuals was estimated to be $0.36 \mathrm{rem} / \mathrm{shipment.} \mathrm{Assuming} \mathrm{a} \mathrm{single}$ escort team accompanies all 282 shipments/yr from eastern reactors and 22 shipments/yr from western reactors, the annual doses to the maximaliy exposed escorts are estimated to be about $102 \mathrm{rem} / \mathrm{yr}$ and $8 \mathrm{rem} / \mathrm{yr}$, respectively.

The maximally exposed railyard workers that are not directly involved with handling the shipments were estimated assuming they are exposed to onefourth of the shipments (i.e., 70 shipments/yr from eastern reactors and 6 shipments/yr from western reactors). The average exposure distance for these individuals is assumed to be $200 \mathrm{~m}$ and the exposure time is assumed to be $12 \mathrm{hr} /$ shipment (DOE 1987a). Therefore, the per-shipment individual doses are estimated to be $0.0013 \mathrm{rem} / \mathrm{hr}$ times $12 \mathrm{hr} / \mathrm{sh}$ ipment or $0.016 \mathrm{rem} / \mathrm{shipment}$. The annual doses to the maximally exposed railyard workers are estimated to be about $1 \mathrm{rem} / \mathrm{yr}$ and $0.1 \mathrm{rem} / \mathrm{yr}$ for shipments from eastern and western reactors, respectively.

\subsection{ANALYSIS OF IN-TRANSIT TRANSPORT OPERATIONS AND DOSES (from-MRS dedicated train rail shipments)}

The analysis of in-transit operational characteristics and routine doses for dedicated train shipments between the MRS facility and the repository is presented in this section. Two potential MRS facility locations, one in the eastern United States and one in the western United States, are considered. 


\subsubsection{In-Transit Operations}

The shipping distances and travel fractions presented in Section 3 were used to develop a time-motion analysis for each potential transport leg (i.e., eastern or western MRS facility to the repository). Average speeds while moving in each population zone plus an average stop-time per shipment were also used. The average travel speeds used were $32 \mathrm{~km} / \mathrm{hr}$ (20 mph) in all three population zones (Wooden 1986). This is the same travel speed that was used for GFR shipments and is believed to be reasonable for this analysis. The average stop-time per trip was calculated using a relationship between stoptime and shipping distance for dedicated trains that was developed by 0stmeyer (1986), as follows:

$$
\mathrm{ST}(\mathrm{d})=2+0.004 * \mathrm{DIST}
$$

where $S T(d)=$ stop-time, $h r$

DIST = one-way shipping distance, $\mathrm{km}$

The time-motion analysis also requires that the number of stops on a representative dedicated train shipment be estimated. Another relationship from Ostmeyer (1986) was used to estimate the number of stops, as shown below:

$$
N=2+0.0018 * \text { DIST }
$$

where $\quad N=$ the number of stops

$$
\text { DIST = one-way shipping distance, } \mathrm{km}
$$

Using these input data, the time-motion analyses for dedicated train shipments presented in Tables 5.11 through 5.14 were developed. Table 5.11 contains the detailed time-motion analysis for a representative dedicated train shipment from the eastern MRS facility site. The important parameters for the dose calculations that were derived from the time-motion analyses are summarized in Table 5.12. Tables 5.13 and 5.14 contain similar information for dedicated train shipments from a western MRS facility site to the Yucca Mountain repository. 
TABLE 5.11. Time-Motion Analysis for Shipment by Dedjicated Train from an
Eastern MRS Facility to the Repository

Activity

Depart Site

Travel to classification terminal

Crew and engine change/inspection

Travel to next yard

Crew change/inspection

Travel to next yard

Crew change/inspection

Travel to next yard

Crew change/inspection

Travel to next yard

Crew change/inspection

Trave 1

Crew change/inspection

Travel

Crew change/inspection

Travel to repository

\begin{tabular}{|c|c|c|c|}
\hline Hours/ & Miles & Cumı & ;ive \\
\hline Activity & Iraveled & Hours & Miles \\
\hline $0: 00$ & 0 & $0: 00$ & 0 \\
\hline $2: 00$ & 40 & $2: 00$ & 40 \\
\hline $1: 00$ & $\cdots$ & $3: 00$ & 40 \\
\hline $15: 00$ & 300 & $18: 00$ & 340 \\
\hline $2: 00$ & -- & $20: 00$ & 540 \\
\hline $10: 00$ & 200 & $30: 00$ & 540 \\
\hline $1: 30$ & -- & $31: 30$ & 540 \\
\hline $10: 00$ & 200 & $41: 30$ & 740 \\
\hline $2: 00$ & -- & $43: 30$ & 740 \\
\hline $10: 00$ & 200 & $53: 30$ & 940 \\
\hline $2: 00$ & -- & $55: 30$ & 940 \\
\hline $10: 00$ & 200 & $65: 30$ & 1140 \\
\hline $2: 00$ & -- & $67: 30$ & 1140 \\
\hline $15: 00$ & 300 & $82: 30$ & 1440 \\
\hline $1: 00$ & $\cdots$ & $83: 30$ & 1440 \\
\hline $1: 30$ & 30 & $85: 00$ & 1470 \\
\hline
\end{tabular}

(a) The number of stops was calculated using the formula given in text and then rounded up to the nearest whole number.

\subsubsection{Collective Doses from Dedicated Rail Shipments (From-MRS-Facility)}

Estimates of the collective radiation doses for the representative dedicated train shipments are developed in this section. As with general freight rail shipments, the doses are received by train crew members, employees at railyards, state inspectors, escorts, and the general public residing near the rail route and railyards. Estimates are also developed for the maximally exposed individuals. The calculations are performed in a manner similar to those described in DOE (1987a), that is, primarily by multiplying together an estimated exposure duration, number of exposed individuals, and a 
TABLE 5.12. Summary of Operational Characteristics of Postulated Dedicated Rail Shipment from the Eastern MRS Facility to the Repository

Aggregated

Total Distance

Moving Time

Stop Time

Total Time

Details

Fractions of Trave1
Number in Crew

Average Speed

Average Speed While Moving:
5

$17.3 \mathrm{mph}$

$20 \mathrm{mph}$

\section{Stops}

- Inspection time (includes state and railroad inspections)

Rural - 86\%

Suburban - $12 \%$

Urban - $2 \%$

- Time for crew change/refueling/ locomotive change

11.5 hours in yards

2 hour/trip

9.5 hours

IABLE 5.13. Time-Motion Analysis for Shipment by Deqdicated Train from a Western MRS Facility to the Repository $(a)$

Activity

Depart site

Travel to classification terminal

Inspection/crew, locomotive change

Travel to next yard

Crew change/inspection

Travel to next yard

Crew change/inspection

Travel to next yard

Crew change/inspection

Travel to next yard

Crew change/inspection

Travel to repository

$\begin{array}{ccc}\text { Hours/ } & \text { Miles } & \text { Cumulative } \\ \text { Activity } & \text { Traveled } & \text { Hours Miles }\end{array}$

$$
0: 00
$$

2:00

0

40

$0: 00$

2:00

3:00

$10: 30$

$12: 30$

$19: 30$

$20: 30$

$30: 30$

$32: 30$

$42: 30$

$43: 30$

$45: 00$

0 40

40

190

190

340

340

$10: 00$

200

540

2:00

200

540

$10: 00$

$--$

20

740

$1: 30$

740

760

(a) The number of stops was calculated using the formula given in text and then rounded up to the nearest whole number. 
TABLE 5.14. Summary of Operational Characteristics of Postulated Dedicated Rail Shipment from the Western MRS Facility to the Repository

\section{Aggregated}

Total Distance

Moving Time

Stop Time

Total Time

$\begin{array}{r}760 \text { miles } \\ \text { 38:00 hours } \\ 7: 00 \text { hours } \\ \hline 45: 00 \text { hours }\end{array}$

Number in Crew

Average Speed

Average Speed While Moving:
5

$16.9 \mathrm{mph}$

$20 \mathrm{mph}$

Details

Fractions of Travel

Rural - $89 \%$

Suburban - 9\%

Urban - $2 \%$

Stops

- Inspection time (includes state and railroad inspections)

7 hours in yards

2 hour/trip

- Time for marshalling/classification/ 5 hours carrier change activities

calculated radiation dose rate at a specified distance. Electronic spreadsheets were developed to facilitate the in-transit dose calculations for dedicated rail shipments. Adjustments were made to the spreadsheets shown in Appendix D of DOE (1987a) to account for the differences in operational characteristics, shipping distances, and travel fractions that were developed for dedicated train shipments.

The spreadsheets for calculating the cumulative radiation doses for dedicated rail shipments are contained in Appendix $C$. The results of all of the potential dedicated train configurations are presented in Tables 5.15 through 5.20. Table 5.15 contains the doses from the representative dedicated train shipment from an eastern MRS facility site to the repository, assuming that fuel assembly hardware (NFBC) will be packaged in canisters and shipped in the same reference casks. Table 5.16 contains similar information as Table 5.15, except the NFBC is assumed to be packaged in 55-gal. drums. Table 5.17 is for dedicated train shipments from a storage-only (no spent fuel consolidation) MRS facility. Tables 5.18 through 5.20 summarize the doses from 

Train Shipments from an Eastern MRS Facility to the Repository NFBC in Canisters

\begin{tabular}{|c|c|c|c|c|}
\hline \multirow[b]{2}{*}{ Exposure Category } & \multicolumn{3}{|c|}{ Collective Doses } & \multirow{2}{*}{$\begin{array}{l}\text { Doses to Maximally } \\
\text { Exposed Individual } \\
\text { (mrem/yr) }\end{array}$} \\
\hline & $\begin{array}{c}\text { Person- } \\
\text { mrem/shipment }\end{array}$ & $\begin{array}{l}\text { Person- } \\
\text { mrem/MTU }(a)\end{array}$ & $\begin{array}{l}\text { Person- } \\
\mathrm{rem} / \mathrm{yr})\end{array}$ & \\
\hline \multicolumn{5}{|l|}{ Transport Workers } \\
\hline Train crew & 29.72 & 0.23 & $\emptyset .61$ & 16.80 \\
\hline Hand lers & 10.66 & 0.68 & 0.22 & 2.85 \\
\hline Yard crew & 8.98 & 0.07 & 0.18 & 0.28 \\
\hline Escorts & 32.27 & 0.25 & 0.66 & 45.60 \\
\hline Inspectors & 4.56 & 0.04 & 0.69 & 11.40 \\
\hline Tota 1 Transport Workers $(c)$ & 86.2 & 0.7 & 1.8 & NA \\
\hline \multicolumn{5}{|l|}{ Public } \\
\hline - While moving & 89.67 & 0.69 & 1.84 & 0.90 \\
\hline - At stops & 4.22 & 0.03 & 0.69 & 0.20 \\
\hline Total Public Dose ${ }^{(c)}$ & 93.9 & 0.7 & 1.9 & NA \\
\hline \multicolumn{5}{|c|}{$\begin{array}{l}\text { NA = Not Applicable } \\
\text { (a) Based on } 129.36 \mathrm{MTU} \text { of consolidated PWR spent fuel and equivalent NFBC waste per shipment. } \\
\text { (b) Based on } 2650 \text { MTU/yr. Considers split between PWR and BWR fuel which affects the number of } \\
\text { shipments to which an individual will be exposed. The annual number of shipments is calculated } \\
\text { by dividing the annual PWR fuel shipment quantity by } 129.36 \mathrm{MTU} / \mathrm{shipment} \text { and adding the result } \\
\text { to the annual BWR fuel shipment quantity divided by } 130.20 \mathrm{MTU} / \text { shipment. } \\
\text { (c) Columns may not add to totals correctly because of round-off. }\end{array}$} \\
\hline
\end{tabular}

\section{TABLE 5.16. Summary of Estimated In-Transit Radiation Doses for Dedicated Train Shipments from an Eastern MRS Facility to the Repository - NFBC in Drums}

\begin{tabular}{|c|c|c|c|c|}
\hline \multirow[b]{2}{*}{ Exposure Category } & \multicolumn{3}{|c|}{ Collective Doses } & \multirow{2}{*}{$\begin{array}{l}\text { Doses to Maximally } \\
\text { Exposed Individual } \\
\text { (mrem/yr) }\end{array}$} \\
\hline & $\begin{array}{l}\text { Person- } \\
\text { mrem/shipment }\end{array}$ & $\begin{array}{r}\text { Person- } \\
\text { mrem/MTU }(a)\end{array}$ & $\begin{array}{l}\text { Person- } \\
\text { rem/yr }\end{array}$ & \\
\hline \multicolumn{5}{|l|}{ Transport Workers } \\
\hline Train crew & 29.72 & 0.23 & 9.61 & 16.80 \\
\hline Handlers & 11.84 & 0.69 & 0.24 & 2.85 \\
\hline Yard crew & 9.97 & 0.08 & 0.20 & 0.28 \\
\hline Escorts & 32.27 & 0.25 & 0.66 & 45.60 \\
\hline Inspectors & 5.06 & 0.04 & 0.10 & 11.40 \\
\hline Total Transport Workers $(c)$ & 88.9 & 0.7 & 1.8 & NA \\
\hline \multicolumn{5}{|l|}{ Public } \\
\hline - While moving & 99.63 & 0.77 & 2.84 & 0.9 \\
\hline - At stops & 4.22 & 0.03 & 9.09 & 0.2 \\
\hline Total Public Dose ${ }^{(c)}$ & 163.9 & 9.8 & 2.1 & NA \\
\hline
\end{tabular}

NA = Not Applicable

(a) Based on 129.36 MTU of consolidated PWR spent fuel and equivalent NFBC waste per shipment.

(b) Based on 2650 MTU/yr. Considers split between PWR and BWR fuel which affects the number of shipments to which an individual will be exposed. The annual number of shipments is calculated by dividing the annual PWR fuel shipment quantity by $129.36 \mathrm{MTU} / \mathrm{sh}$ ipment and adding the result to the annual BWR fuel shipment quantity divided by $130.20 \mathrm{MTU} / \mathrm{sh}$ ipment.

(c) Columns may not add to totals correctly because of round-off. 
TABLE 5.17. Summary of Estimated In-Transit Radiation Doses for Dedicated Train Shipments from an Eastern MRS Facility to the Repository No Fuel Consolidation

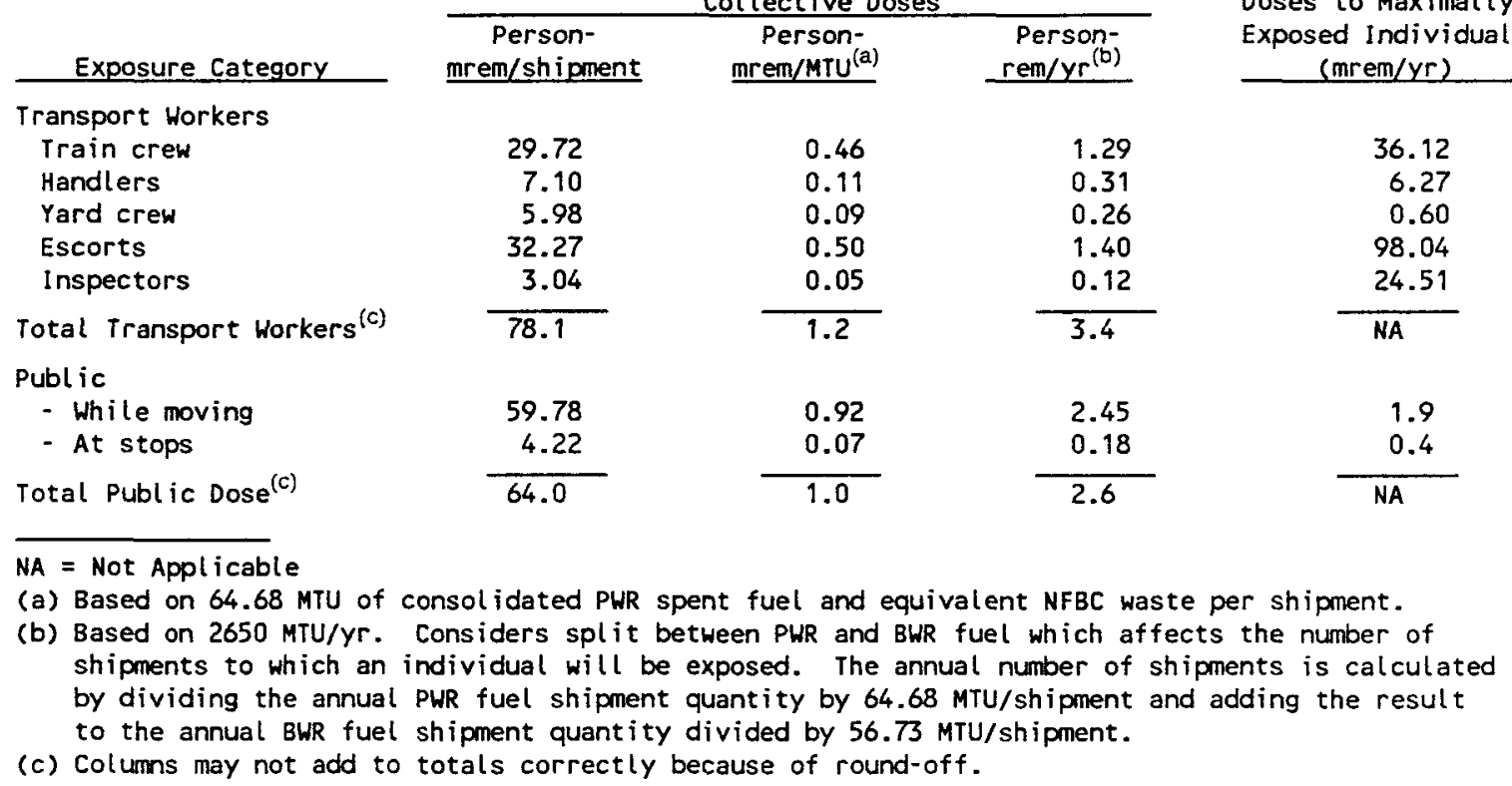

TABLE 5.18. Summary of Estimated In-Transit Radiation Doses for Dedicated Train Shipments from a Western MRS Facility to the Repository NFBC in Canisters

\begin{tabular}{|c|c|c|c|c|}
\hline \multirow[b]{2}{*}{ Exposure Category } & \multicolumn{3}{|c|}{ Collective Doses } & \multirow{2}{*}{$\begin{array}{c}\text { Doses to Maximally } \\
\text { Exposed Individual } \\
\text { (mrem/yr) } \\
\end{array}$} \\
\hline & $\begin{array}{c}\text { Person- } \\
\text { mrem/shipment }\end{array}$ & $\begin{array}{c}\text { Person- } \\
\text { mrem/MTU } \\
\end{array}$ & $\begin{array}{l}\text { Person- } \\
\text { rem/yr }{ }^{(b)} \\
\end{array}$ & \\
\hline \multicolumn{5}{|l|}{ Transport Workers } \\
\hline Train crew & 15.75 & 0.12 & 0.36 & 19.32 \\
\hline Handlers & 7.17 & 0.06 & 0.17 & 3.42 \\
\hline Yard crew & 6.04 & 0.05 & 0.14 & 0.32 \\
\hline Escorts & 17.10 & 0.13 & 0.40 & 52.44 \\
\hline Inspectors & 4.56 & 0.04 & 0.11 & 13.11 \\
\hline Total Transport Workers ${ }^{(c)}$ & 50.6 & 0.4 & 1.2 & NA \\
\hline \multicolumn{5}{|l|}{ Publ ic } \\
\hline - While moving & 42.17 & 0.33 & 0.98 & 1.0 \\
\hline - At stops & 2.55 & 0.02 & 0.06 & 0.2 \\
\hline Total Public Dose $\mathrm{e}^{(c)}$ & 44.7 & 0.4 & 1.0 & NA \\
\hline \multicolumn{5}{|c|}{$\begin{array}{l}\text { NA = Not Applicable } \\
\text { (a) Based on } 129.36 \mathrm{MTU} \text { of consolidated PWR spent fuel and equivalent NFBC waste per shipment. } \\
\text { (b) Based on } 3000 \mathrm{MTU} / \mathrm{Y} \text {. Considers split between PWR and BWR fuel which affects the number of } \\
\text { shipments to which an individual will be exposed. The annual number of shipments is calculated } \\
\text { by dividing the annual PWR fuel shipment quantity by } 129.36 \mathrm{MTU} / \mathrm{sh} \text { ipment and adding the result } \\
\text { to the annual BWR fuel shipment quantity divided by } 130.20 \mathrm{MTU} / \mathrm{sh} \text { ipment. } \\
\text { (c) Columns may not add to totals correctly because of round-off. }\end{array}$} \\
\hline
\end{tabular}




\section{TABLE 5.19. Summary of Estimated In-Transit Radiation Doses for Dedicated Train Shipments from a Western MRS Facility to the Repository - NFBC in Drums}

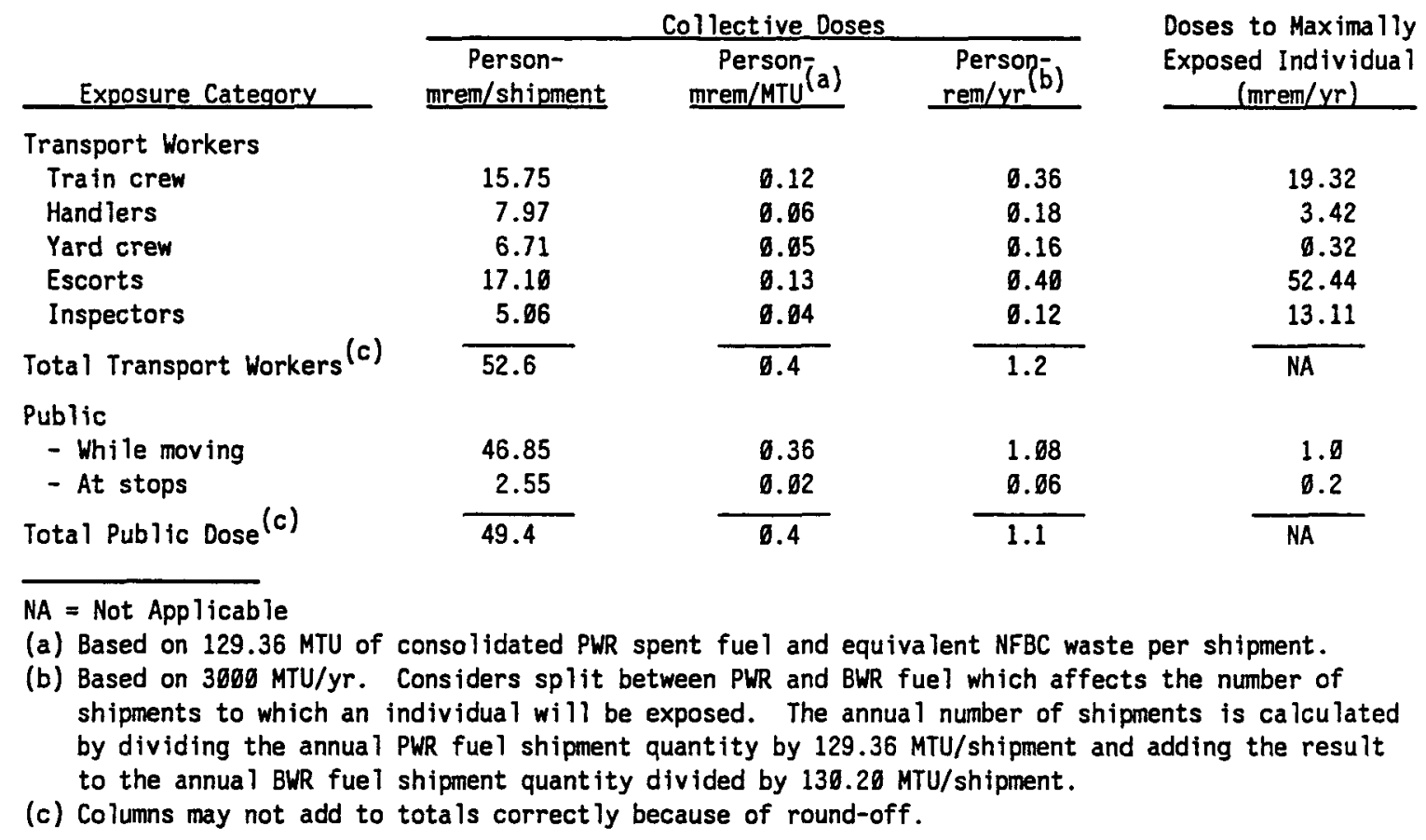

\section{TABLE 5.20. Summary of Estimated In-Transit Radiation Doses for Dedicated Train Shipments from a Western MRS Facility to the Repository - No Fuel Consolidation}

\begin{tabular}{|c|c|c|c|c|}
\hline \multirow[b]{2}{*}{ Exposure Category } & \multicolumn{3}{|c|}{ Collective Doses } & \multirow{2}{*}{$\begin{array}{l}\text { Doses to Maximally } \\
\text { Exposed Individua } 1 \\
\text { (mrem/yr) }\end{array}$} \\
\hline & $\begin{array}{c}\text { Person- } \\
\text { mrem/shipment }\end{array}$ & P/MTU $(a)$ & $\begin{array}{l}\text { Person- } \\
\mathrm{rem} / \mathrm{yr}(\mathrm{b})\end{array}$ & \\
\hline \multicolumn{5}{|l|}{ Transport Workers } \\
\hline Train crew & 15.75 & 0.24 & 0.77 & 41.16 \\
\hline Handlers & 4.78 & 0.07 & 0.23 & 6.84 \\
\hline Yard crew & 4.03 & 0.06 & 0.20 & 0.69 \\
\hline Escorts & 17.10 & 0.26 & 0.83 & 111.72 \\
\hline Inspectors & 3.05 & 0.65 & 0.15 & 27.93 \\
\hline Total Transport Workers ${ }^{(c)}$ & 44.7 & 0.7 & 2.2 & NA \\
\hline \multicolumn{5}{|l|}{ Public } \\
\hline - While moving & 28.10 & 0.43 & 1.30 & 2.2 \\
\hline - At stops & 2.55 & 0.04 & 0.12 & 0.5 \\
\hline Total Public Dose ${ }^{(c)}$ & 30.7 & 0.5 & 1.4 & NA \\
\hline \multicolumn{5}{|c|}{$\begin{array}{l}\text { NA = Not Applicable } \\
\text { (a) Based on } 64.68 \mathrm{MTU} \text { of consolidated PWR spent fuel per shipment. } \\
\text { (b) Based on } 3000 \mathrm{MTU} / \mathrm{yr} \text {. Considers split between PWR and BWR fuel which affects the number of } \\
\text { shipments to which an individual will be exposed. The annual number of shipments is calculated } \\
\text { by dividing the annual PWR fuel shipment quantity by } 64.68 \mathrm{MTU} / \mathrm{shipment} \text { and adding the result } \\
\text { to the annual BUR fuel shipment quantity divided by } 56.73 \mathrm{MTU} / \mathrm{sh} \text { ipment. } \\
\text { (c) Columns may not add to totals correctly because of round-off. }\end{array}$} \\
\hline
\end{tabular}


dedicated train shipments from a western MRS facility to the repository. Table 5.18 is for dedicated trains containing consolidated fuel and NFBC packaged in canisters; Table 5.19 assumes the NFBC is packaged in 55-gal. drums; and Table 5.20 is for dedicated train shipments from a storage-only (no spent fuel consolidation) MRS facility. Each table contains the results of the calculation of unit dose (on dose-per-shipment and dose-per-MTU bases), the annual doses, and the results of the calculations of the doses to the maximally exposed individuals.

The bases and assumptions for the exposure distances used to calculate the doses from the dedicated train shipments are as follows. The workeroccupied location closest to a spent fuel cask was estimated at $30 \mathrm{~m}$ or 1.5 railcar lengths. This assumption is based on a railcar length of approximately $20 \mathrm{~m}$ and accounts for an intervening flatcar between the locomotive and the first spent fuel railcar. Assuming that the shipping cask is placed at the mid-point of the railcar and that the crew members are at the rear of the locomotive, this results in the crew members being about 1.5 railcar lengths from the nearest cask. It is assumed that the exposure rate to the train crew from the following railcar casks are insignificant. Exposure distances for escorts are changed from $50 \mathrm{~m}$ to $30 \mathrm{~m}$ to reflect this difference in train characteristics.

Exposure distances for the yard crew and train handlers are taken to be the same as those used in DOE (1987a). The number of train handlers is assumed to be 3 for dedicated train shipments, because the dedicated trains generally travel directly through the railyard and are not subjected to classification activities (Ostmeyer 1986). Therefore, the number of train handlers would be substantially smaller for dedicated trains.

The dose factors that are used to calculate the doses to the public while the train is moving are the same for dedicated trains and GFR shipments. Information provided by Ostmeyer (1986) is used to derive this conclusion. Population doses at stops are different because of the significantly smaller times spent in railyards. Therefore, the spreadsheets reflect these much smaller exposure times for dedicated train shipments than those used for GFR shipments. 


\subsubsection{Maximally Exposed Individuals from Dedicated Train Shipments}

Estimates of the annual doses to maximally exposed individuals for the representative dedicated train shipments are developed in this section. The approach used to develop these estimates is similar to that described for truck shipments. The results of these calculations are presented in Tables 5.15 through 5.20 for the dedicated train shipments from eastern and western MRS facilities. The individual doses in the tables were developed based on the split between the annual number of shipments of PWR and BWR fuel from the MRS facility. The annual number of shipments is calculated by dividing the annual PWR fuel shipment quantity by the PWR fuel shipment capacity and adding the result to the annual BWR fuel shipment quantity divided by the BWR shipment capacity.

The maximum individual doses for the two NFBC packaging options (i.e., canisters vs. drums) are approximately the same because the total number of shipments is identical. However, the storage-only MRS facility options result in higher maximum individual doses for the representative dedicated train shipments because the annual number of shipments is higher. The maximum individual doses for the non-consolidated fuel shipments are the ratio of the annual numbers of shipments times the maximum individual doses for the consolidated fuel options. Therefore, the maximum individual doses for the western storage-only MRS option are approximately 2.13 times the maximum individual

doses for the consolidation option. The multiplication factor for the eastern storage-only MRS option is approximately 2.15. In the following discussion, only the maximum individual doses for the consolidation option are presented.

The maximum individual doses to train crew members were estimated assuming that the longest train run for an individual crew member is $12 \mathrm{hr}$ (same as for GFR shipments). As discussed previously, the exposure distance for train crew members is estimated at $30 \mathrm{~m}$ from the top of the cask, so the dose rate is $0.07 \mathrm{rem} / \mathrm{hr}$ (DOE 1987a). Assuming that the train crew delivers all 20 dedicated train shipments/yr from the eastern MRS facility to the repository, the total annual dose is estimated to be $17 \mathrm{rem} / \mathrm{yr}$. Assuming that the train crew delivers all 23 dedicated train shipments/yr from the western MRS 
facility to the repository, the estimated total annual dose to the maximally exposed crew member about $19 \mathrm{rem} / \mathrm{yr}$.

Annual doses to train handlers were estimated assuming an individual train handler spends approximately $5 \mathrm{~min} / \mathrm{railcar}$ in close proximity to the shipment. There are 5 casks of spent fuel and 4 casks of NFBC when fuel is consolidated at the MRS and 5 casks of intact spent fuel in each dedicated train from a store-only MRS. As a result, the maximum exposure time is estimated at $45 \mathrm{~min} / \mathrm{train}$. The exposure distance is assumed to be $10 \mathrm{~m}$ from the side of the cask, so the dose rate is estimated at $0.76 \mathrm{rem} / \mathrm{hr}$ (DOE 1987a). Assuming that the maximally exposed individual works at the railyard nearest to the repository and the railyard operates on a 4 shift, 24 hours/day, 7 days/week basis, the maximally exposed individual would be exposed to approximately 5 shipments/yr from an eastern MRS facility and 6 shipments/yr from a western MRS facility. The estimated annual dose to the maximally exposed train handler about 2.9 and $3.4 \mathrm{rem} / \mathrm{yr}$, respectively.

The annual dose to a railyard employee not directly involved in handling the shipment is estimated assuming this person is located $30 \mathrm{~m}(100 \mathrm{ft})$ from the side of the passing train. According to Martin and Levitch (1988), an individual in this location would receive approximately 0.014 rem from a passing dedicated train. Assuming this person is exposed to all 20 shipments/yr from an eastern MRS facility or a11 23 shipments/yr from a western MRS facility, the estimated annual dose to the maximally exposed railyard worker is about 0.28 or $0.32 \mathrm{rem} / \mathrm{yr}$, respectively.

Escorts are assumed to accompany the dedicated train at an exposure distance of $30 \mathrm{~m}$. The dose rate at this distance is approximately $0.19 \mathrm{rem} / \mathrm{hr}$ (DOE 1987a). Assuming this individual accompanies all 20 or 23 dedicated train shipments/yr for the final 12 hours of the shipment, the estimated annual dose to the maximally exposed escort is about 46 or $52 \mathrm{rem} / \mathrm{yr}$, respectively, for shipments from an eastern or western MRS facility.

Annual doses to state inspectors were calculated assuming the inspectors spend approximately $5 \mathrm{~min} / \mathrm{railcar}$ (exposure duration of $45 \mathrm{~min} / \mathrm{train}$ as discussed above for train handlers) at an average distance of $10 \mathrm{~m}$ from the side of the casks. The dose rate at this distance is estimated at $0.76 \mathrm{rem} / \mathrm{hr}$ (DOE 
1987a). Assuming that an individual state inspector inspects al1 20 dedicated train shipments/yr from an eastern MRS facility or all 23 shipments/yr from a western MRS facility, the estimated annual dose to the maximally exposed inspector is approximately $11 \mathrm{rem} / \mathrm{yr}$ or $13 \mathrm{rem} / \mathrm{yr}$, respectively.

The annual dose to the maximally exposed member of the public is calculated for a person residing $30 \mathrm{~m}$ from a railroad that is used to transport all 20 shipments/yr from an eastern MRS facility to the repository or all 23 shipments/yr from a western MRS facility (i.e., this individual resides along the route leading from the last railyard to the repository site). The per-shipment dose is estimated using the dose factor for GFR shipments given previously ( $0.00504 \mathrm{rem} / \mathrm{shipment})$ and multiplying by 9 casks to account for the dedicated train. This results in a dose factor of 0.045 rem per 9 -car dedicated train. The estimated annual dose to the maximally exposed member of the public residing near a rail track is about 0.9 or $1.0 \mathrm{rem} / \mathrm{yr}$, respectively.

The maximum individual dose to a member of the public that resides near a railyard was calculated by assuming that this person resides $300 \mathrm{~m}$ from the last railyard enroute to the repository. The dose rate at $300 \mathrm{~m}$ from the sides of the casks is $0.00055 \mathrm{rem} / \mathrm{hr}$ (DOE 1987a). Assuming this person is present for the entire $2 \mathrm{hr} / \mathrm{stop}$ and that passage of 9 railcar casks (5 casks of fuel, 4 casks of NFBC) in a single dedicated train produces 9 times the radiation dose as passage of a single railcar cask, this person is estimated to receive $0.01 \mathrm{rem} / \mathrm{shipment.} \mathrm{Assuming} \mathrm{this} \mathrm{person} \mathrm{is} \mathrm{present} \mathrm{as} \mathrm{all} 20$ dedicated train shipments/yr from an eastern MRS facility pass by or all or 23 shipments/yr from a western MRS facility pass by, the estimated annual dose to the maximally exposed member of the public residing near a railyard is about $0.20 \mathrm{rem} / \mathrm{yr}$ or $0.23 \mathrm{rem} / \mathrm{yr}$, respectively.

\subsection{ANNUAL SYSTEM RADIATION DOSES FROM IN-TRANSIT OPERATIONS}

Estimates of the total annual system doses from in-transit activities are developed in this section. These doses were estimated by adding together the calculated annual doses for the appropriate transport segments that constitute the waste management system with an integral MRS facility. The 
annual system doses for two system configurations are estimated (i.e., one with an eastern MRS facility and one with a western MRS facility.

Annual system doses were calculated by multiplying the annual shipment quantities (given in Section 3 ) by the appropriate unit doses (person-rem/MTU) calculated previously. The calculated annual system doses for both MRS facility siting assumptions, for both NFBC packaging assumptions, and for the storage-only MRS facility configuration are presented in Table 5.21, together with the annual in-transit doses for the FWMS in the No-MRS scenario (DOE 1987a). These in-transit doses are illustrated in Figure 5.1.

The results indicate that the system configuration that produces the lowest in-transit radiation dose commitment is the system with an MRS facility located in the eastern United States Dose reductions of about $40 \%$ and $50 \%$ relative to the non-MRS system and the system with a western MRS facility, respectively, are achievable if an MRS facility is constructed in the east. These reductions arise primarily from locating the MRS facility site near the locations of most reactors, which are concentrated in the eastern United

TABLE 5.21. Estimated Total Annual System Doses for In-Transit Operations in the Waste Management System with an MRS Facility

\begin{tabular}{|c|c|c|c|c|c|}
\hline \multirow[b]{3}{*}{$\begin{array}{c}\text { Affected } \\
\text { Population Group }\end{array}$} & \multicolumn{4}{|c|}{ Annual System Collective Dose, person-rem/yr } & \multirow[b]{3}{*}{$\begin{array}{l}\text { System with No } \\
\text { MRS Facility }\end{array}$} \\
\hline & \multicolumn{2}{|c|}{ Eastern MRS Facflity } & \multicolumn{2}{|c|}{ Western MRS Facility } & \\
\hline & $\begin{array}{l}\text { NFBC in Canisters } \\
\text { or Drums } \\
\end{array}$ & $\begin{array}{l}\text { Storage-only } \\
\text { MRS Facility }\end{array}$ & $\begin{array}{l}\text { NFBC in Canisters } \\
\text { or Drums } \\
\end{array}$ & $\begin{array}{l}\text { Storage-only } \\
\text { MRS Facility }\end{array}$ & \\
\hline \multicolumn{6}{|l|}{ Transport Workers } \\
\hline Truck & 129 & 129 & 244 & 244 & 201 \\
\hline Rail & 14 & 14 & 21 & 21 & 21 \\
\hline Dedicated Train & 2 & 3 & 1 & $\underline{2}$ & $\mathrm{NA}$ \\
\hline Subtotal - Workers & $\overline{145}$ & $\overline{146}$ & $\overline{266}$ & $\overline{287}$ & 222 \\
\hline \multicolumn{6}{|l|}{ Public } \\
\hline Truck & 251 & 251 & 525 & 525 & 444 \\
\hline $\operatorname{Ra} i 1$ & 10 & 10 & 13 & 13 & 12 \\
\hline Dedicated Train & $\underline{2}$ & $\underline{3}$ & 1 & $\underline{2}$ & NA \\
\hline Subtotal - Public & 263 & $\overline{264}$ & 539 & 540 & 456 \\
\hline GRAND TOTAL & 468 & 410 & 806 & 868 & 678 \\
\hline
\end{tabular}




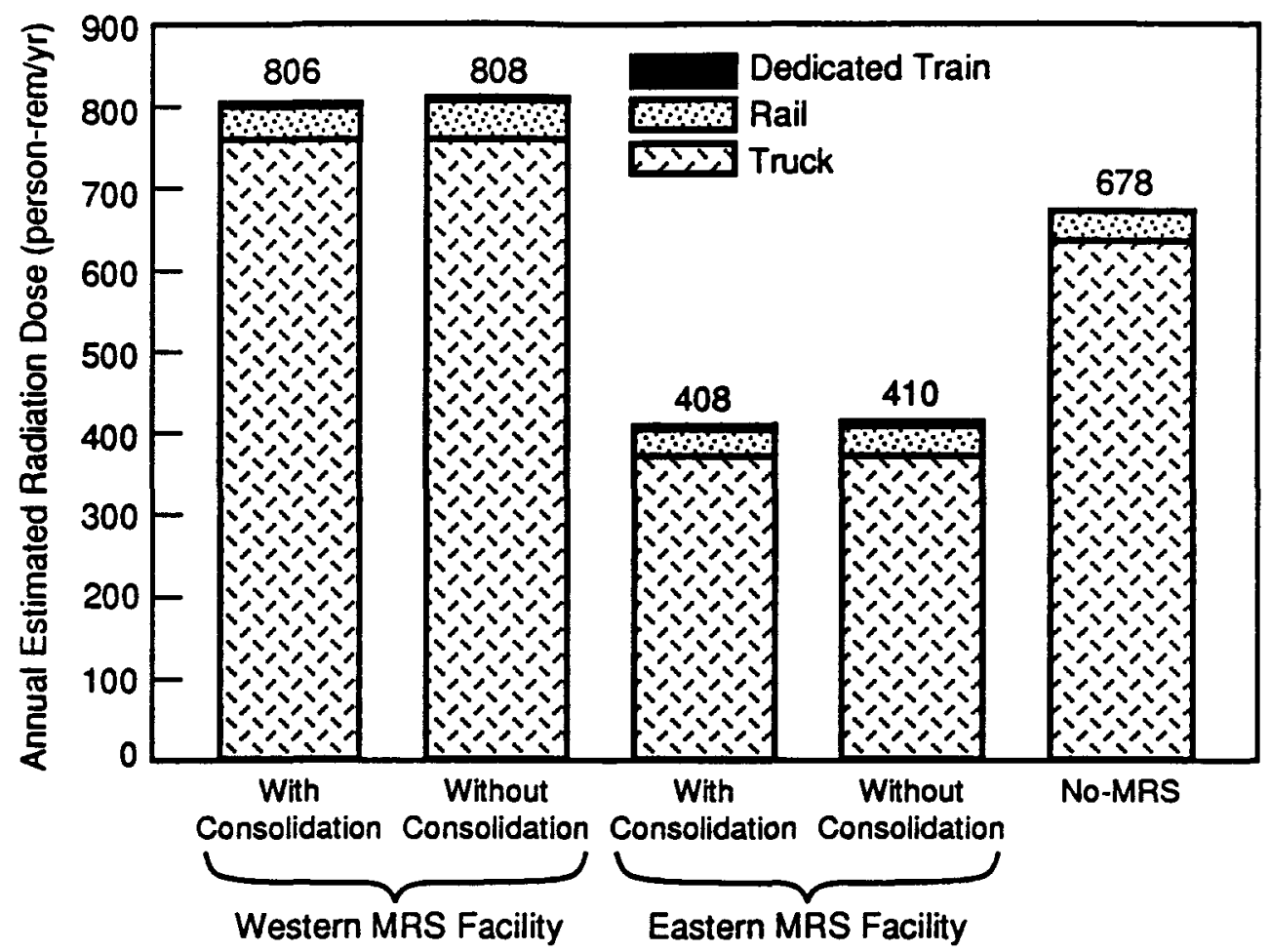

FIGURE 5.1. Comparison of Estimated Annual In-Transit Radiation Doses for Systems With and Without an MRS Facility

States. This results in shorter shipping distances for a large fraction of the spent fuel shipments (i.e., the shipments that originate from eastern reactors).

Comparisons of the in-transit doses between the two NFBC packaging options and the storage-only MRS facility configuration indicate there is little difference in public and worker doses from in-transit activities. This is because the total transport system radiation doses are dominated by the truck and rail shipments to the MRS facility. Since these three options only affect the characteristics of shipments from the MRS facility to the repository, the specific MRS facility configuration or NFBC packaging option has little effect on the total annual in-transit doses. 


\subsection{COMPARISON OF THE MRS SCENARIOS WITH THE NO-MRS SCENARIO}

The annual radiation doses to workers at the reactors due to spent fuel shipping operations and to workers at the FWMS facilities (MRS and repository) are summarized for the four system scenarios containing an MRS facility and for the reference No-MRS facility scenario in Table 6.1. Also presented in the table are the cumulative annual radiation doses to workers engaged in the

TABLE 6.1. Comparison of Estimated Cumulative Annual Radiation Doses in a Waste Management System With and Without an MRS Facility (person-rem/year)

\begin{tabular}{|c|c|c|c|c|c|c|c|}
\hline $\begin{array}{l}\text { System (a) } \\
\text { Scenario }\end{array}$ & $\begin{array}{l}\text { At-Reactor } \\
\text { Loading } \\
\end{array}$ & $\begin{array}{l}\text { Reactor/ } \\
\text { MRS } \\
\end{array}$ & $\begin{array}{l}\text { Reactor/ } \\
\text { Repos. }\end{array}$ & $\begin{array}{l}\text { MRS Facility } \\
\text { Receive/Ship (b) }\end{array}$ & $\begin{array}{l}\text { In-Transit } \\
\text { MRS/Repos. }\end{array}$ & $\begin{array}{c}\text { Repository } \\
\text { Receive } \\
\end{array}$ & $\begin{array}{l}\text { System } \\
\text { Tota } 1 \mathbf{s}\end{array}$ \\
\hline \multicolumn{8}{|l|}{ EMRS (CSF) } \\
\hline $\begin{array}{l}\text { Facility Worker } \\
\text { Trans. Worker } \\
\text { Public }\end{array}$ & $\begin{array}{r}436.1 \\
0.2\end{array}$ & $\begin{array}{l}114.2 \\
204.8\end{array}$ & $\begin{array}{l}28.9 \\
56.2\end{array}$ & $\begin{array}{c}368.4 / 71.8-87.6 \\
1.1 / 0.3-6.4\end{array}$ & $\begin{array}{c}1.6 \\
1.9-2.1\end{array}$ & $\begin{array}{c}134.2-147.8 \\
0.6-0.6\end{array}$ & $\begin{array}{c}1010.0 / 1030 \\
147.0 \\
263.1 \\
1420-14 \\
.\end{array}$ \\
\hline \multicolumn{8}{|l|}{ WMRS (CSF) } \\
\hline $\begin{array}{l}\text { Facility Worker } \\
\text { Trans. Worker } \\
\text { Public }\end{array}$ & $\begin{array}{r}436.1 \\
9.2\end{array}$ & $\begin{array}{l}265.7 \\
538.2\end{array}$ & $\begin{array}{l}\text { NA } \\
\text { NA }\end{array}$ & $\begin{array}{c}439.7 / 80.8-98.1 \\
1.3 / 9.4-0.5\end{array}$ & $\begin{array}{l}1.2 \\
1.0-1.1\end{array}$ & $\begin{array}{c}69.0-83.8 \\
0.2-0.2\end{array}$ & $\begin{array}{c}1025.6 / 105 \\
269.1 \\
539.3 \\
1834-18\end{array}$ \\
\hline \multicolumn{8}{|l|}{ EMRS (ISF) } \\
\hline $\begin{array}{l}\text { Facility Worker } \\
\text { Trans. Worker } \\
\text { Public }\end{array}$ & $\begin{array}{r}436.1 \\
0.2\end{array}$ & $\begin{array}{l}114.2 \\
204.8\end{array}$ & $\begin{array}{l}28.9 \\
56.2\end{array}$ & $\begin{array}{c}368.4 / 113.2 \\
1.1 / 0.5\end{array}$ & $\begin{array}{l}3.5 \\
2.8\end{array}$ & $\begin{array}{r}169.7 \\
0.6\end{array}$ & $\begin{array}{r}1086.8 \\
149.6 \\
263.8 \\
1500\end{array}$ \\
\hline \multicolumn{8}{|l|}{ WMRS (ISF) } \\
\hline $\begin{array}{l}\text { Facility Worker } \\
\text { Trans. Worker } \\
\text { Public }\end{array}$ & $\begin{array}{r}436.1 \\
0.2\end{array}$ & $\begin{array}{l}265.7 \\
538.2\end{array}$ & $\begin{array}{l}N A \\
N A\end{array}$ & $\begin{array}{c}439.7 / 127.7 \\
1.3 / 0.6\end{array}$ & $\begin{array}{l}2.3 \\
1.5\end{array}$ & $\begin{array}{r}109.0 \\
0.3\end{array}$ & $\begin{array}{r}1112.5 \\
270.4 \\
539.7 \\
1923\end{array}$ \\
\hline \multicolumn{8}{|l|}{ No-MRS (ISF) } \\
\hline $\begin{array}{l}\text { Fac } f 1 \text { ity Worker } \\
\text { Trans. Worker } \\
\text { Public }\end{array}$ & $\begin{array}{r}436.1 \\
0.2\end{array}$ & $\begin{array}{l}\text { NA } \\
\text { NA }\end{array}$ & $\begin{array}{l}221.6 \\
456.4\end{array}$ & NA/NA & $\begin{array}{l}\text { NA } \\
\text { NA }\end{array}$ & $\begin{array}{r}439.7 \\
1.3\end{array}$ & $\begin{array}{l}875.8 \\
222.9 \\
\frac{456.4}{1555}\end{array}$ \\
\hline
\end{tabular}

(a) EMRS means eastern MRS, WMRS means western MRS, CSF means consolidated spent fuel, and ISF means intact spent fuel.

(b) Dual dose values refer to packaging NFBC in 9-in. canisters or in 55-gallon drums.

Note: Doses resulting from Cask Maintenance Facility operations are not included in these values. 
transport of spent fuel from the reactors to the FWMS facilities, and the cumulative annual dose to members of the general public as a result of the transport operations. The in-transit dose estimates are extracted from Chapter 5 of this report for the MRS scenarios and from the original study (DOE 1987a) for the No-MRS scenario. These radiation dose estimates are also illustrated in Figure 6.1 for each of the scenarios evaluated, distributed by doserecipient category. These same estimated doses are illustrated again in Figure 6.2 , distributed by the location in the system that the dose is accumulated.

It can be seen from Table 6.1 and Figure 6.1 that the eastern MRS/ consolidated fuel scenario results in the least radiation dose to the transport workers and to the general public, roughly a factor of 1.7 lower than the No-MRS scenario. On the other hand, the dose to the facility workers in the No-MRS scenario is about 15\% to $18 \%$ less than in the best of the MRS scenarios. There is very little difference in the doses to transport workers and

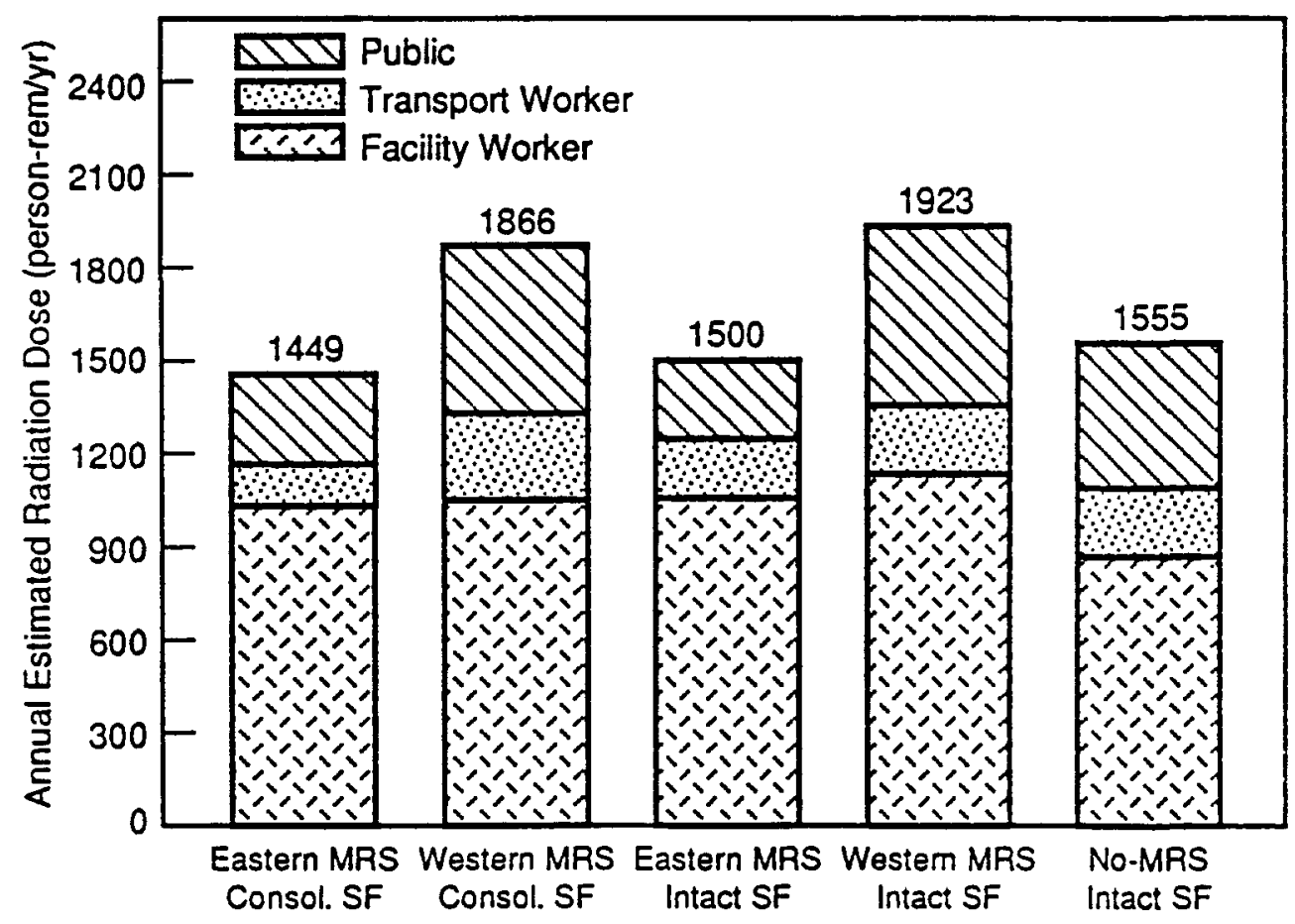

FIGURE 6.1. Distribution of Estimated Annual Dose by Recipient Category 


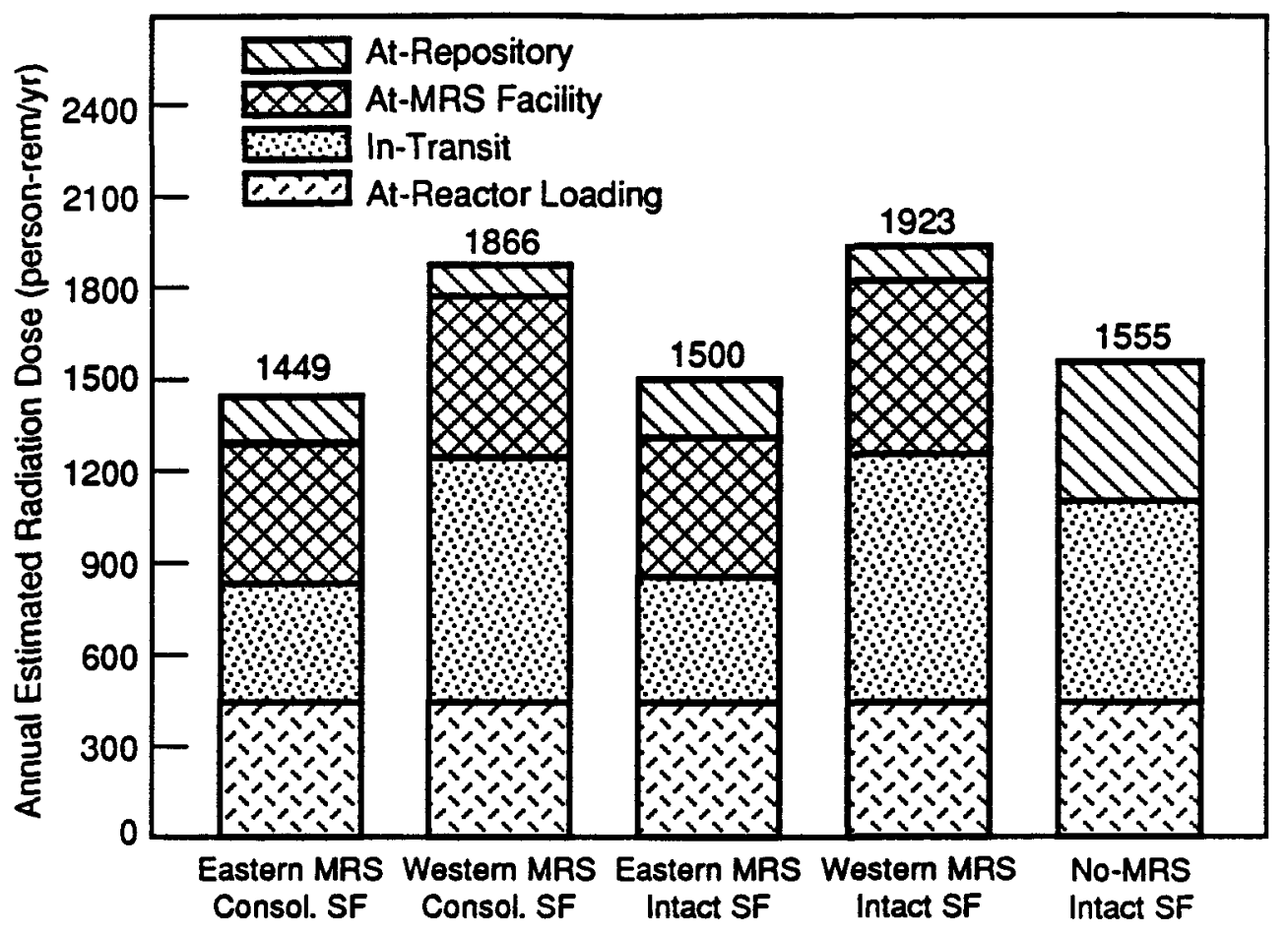

FIGURE 6.2. Distribution of Estimated Annual Dose by System Location

the general public for a given MRS location whether or not the fuel is consolidated, and only about an $5 \%$ to $8 \%$ difference in the facility worker dose (smaller for consolidated fuel).

Several inferences can be made from the results of the analyses presented in this report:

- The addition of an eastern MRS facility to the FWMS increases the cumulative radiation dose to facility workers by $15 \%$ to $18 \%$, relative to the No-MRS system. However, the cumulative dose to all dose recipients (facility workers, transport workers, and the general public) is about $7 \%$ less for the MRS system.

- The very large radiation doses to maintenance-craftsmen in the system will necessitate the introduction of remote/automated equipment for performing the cask receiving/shipping operations at both the MRS facility and the repository, to assure meeting the NRC dose limit and the DOE target dose. 
- Public perception about the benefits of the reduction in dose to transport workers and to the general public in the consolidated fuel scenarios may influence the decision on whether or not to incorporate spent fuel consolidation into an MRS facility. 


\subsection{REFERENCES}

Martin, J. E., and C. Levitch. 1988. "Factors Affecting Radiation Doses from Dedicated Rail Transport of Spent Reactor Fuel." Radiation Protection Management, Volume 5, No. 3. The Techrite Co., Kentwood, Michigan.

Ostmeyer, R. M. 1986. A Revised Rail-Stop Exposure Model for Incident-Free Transport of Nuclear Waste. SAND85-2149. Sandia National Laboratories, Albuquerque, New Mexico.

Ralph M. Parsons Co. (Parsons). 1985. Integral Monitored Retrievable (MRS) Storage Facility Conceptual Design Report. MRS-11, The Ralph M. Parsons Co., Pasadena, California.

U.S. Department of Energy (DOE). 1986. Environmental Assessment, Yucca Mountain Site, Nevada Research and Development Areas, Nevada. DOE/RW-0073, U.S. Department of Energy, Washington, D.C.

U.S. Department of Energy (DOE). 1987a. Analyses of Radiation Doses from Operation of Postulated Commercial Spent Fuel Transportation Systems. DOE/CH-TPO-01, Prepared by the Pacific Northwest Laboratory for the U.S. Department of Energy - Chicago Operations Office, Argonne, Illinois.

U.S. Department of Energy (DOE). 1987b. MRS Submission to Congress. Volume II - Environmental Assessment for a Monitored Retrievable Storage Facility. D0E/RW-0035, Rev. 1, U.S. Department of Energy, Washington D.C.

Wooden, D. G. 1986. Railroad Transportation of Spent Nuclear Fuel. SAND86-7083. Sandia National Laboratories, Albuquerque, New Mexico.

Woods, W. D., A. K. Jowdy, C. H. Keehn, R. M. Gale, and R. I. Smith. 1988. MRS Action Plan Task B Report: Analyses of Alternative Designs and Operating Approaches for a Monitored Retrievable Storage Facility. PNL-6770, Prepared by Ralph M. Parsons Company of Delaware for Pacific Northwest Laboratory, Richland, Washington. 


\section{APPENDIX A}

IIME/DISTANCE/DOSE CALCULATIONS FOR 150-TON CASK HANDLING AT MRS 
APPENDIX A

\section{IIME/DISTANCE/DOSE CALCULATIONS FOR 150-TON CASK HANDLING AT MRS}

This appendix contains the detailed spreadsheet used to calculate the radiation doses received by MRS facility workers during the operations of receiving an empty cask from the repository, loading the cask with spent fuel and/or packaged NFBC, and preparing the cask for shipment to the repository.

The time steps, dose rates, and staffing levels involved in the cask handling operations are, for the most part, identical with those developed in the appendixes to DOE (1987a). Some small changes have been made, where appropriate, to reflect the longer time required to load the larger-capacity cask, the increased QC inspections needed to prepare the loaded cask for shipment, and the increased dose rates associated with decontamination of the exterior of the loaded cask.

The operations and doses shown in the spreadsheet represent those necessary for processing a single 150-ton rail cask through the MRS facility. To calculate the annual doses to the facility staff, the doses resulting from operations on a single cask must be multiplied by the number of casks handled by the staff during a year.

Twenty-four major activities have been identified for the processing of a cask through the MRS facility. Each of those activities has a number of individual steps within it to accomplish its purpose. The attached spreadsheet contains all of the activities and all of the steps within each activity, the types and number of staff involved in each step, the time duration of exposure to radiation, and the radiation dose rate during that exposure period, for each staff member. The radiation dose to each staff member during each step is computed as the product of (the time in radiation field) $X$ (dose rate in the radiation field). There are two components of this calculation, one for the dose rate and time of exposure in the general work area and one 
for the dose rate and time of exposure in the immediate vicinity of the cask. The two components are summed to provide the total dose to a worker resulting from a given step in an activity.

The types and numbers of staff required to carry out the cask handing operations at the MRS facility are given in Table A.1. These staff members perform all of the cask handling operations at the MRS facility, both for incoming and outgoing casks. These same types and numbers of staff are required for the cask handling operations at the repository.

There is one other category of workers shown in the spreadsheet, an engine driver (ED). This category is part of the transportation worker population, not of the facility worker population. Thus, the doses received by these workers during operations at the MRS facility fall into the transport worker dose totals. While the number of individuals involved in the at-facility transportation operations is not well-defined, the dose per cask is available from the spreadsheet: Engine Driver (rail) (2.500 $\mathrm{mrem} / \mathrm{cask}$ ). Thus, the cumulative annual dose to this worker category from the at-facility operations can be calculated, knowing the annual number of casks passing through the facilities.

TABLE A.1. Types and Numbers of Staff Required for 150-Ton Cask Handling Operations at the MRS Facility

\section{Type of Staff}

Radiation Monitor (RM1, RM2)

Security Guard (SG1, SG2)

Faci1ity Operator (OP1, OP2, OP3, OP4)

Maintenance-Craftsmen (MC1)

Quality Technician (QC1, QC2)

Yard Engine Driver (YD)

Crane Operator (CO)

Total Dose per Cask

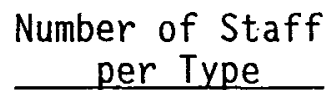

10

8

43

24

12

4

6
Dose per Cask (mrem/cask)

38.804

1.734

52.302

397.983

27.066

2.499

3.109

523.490 


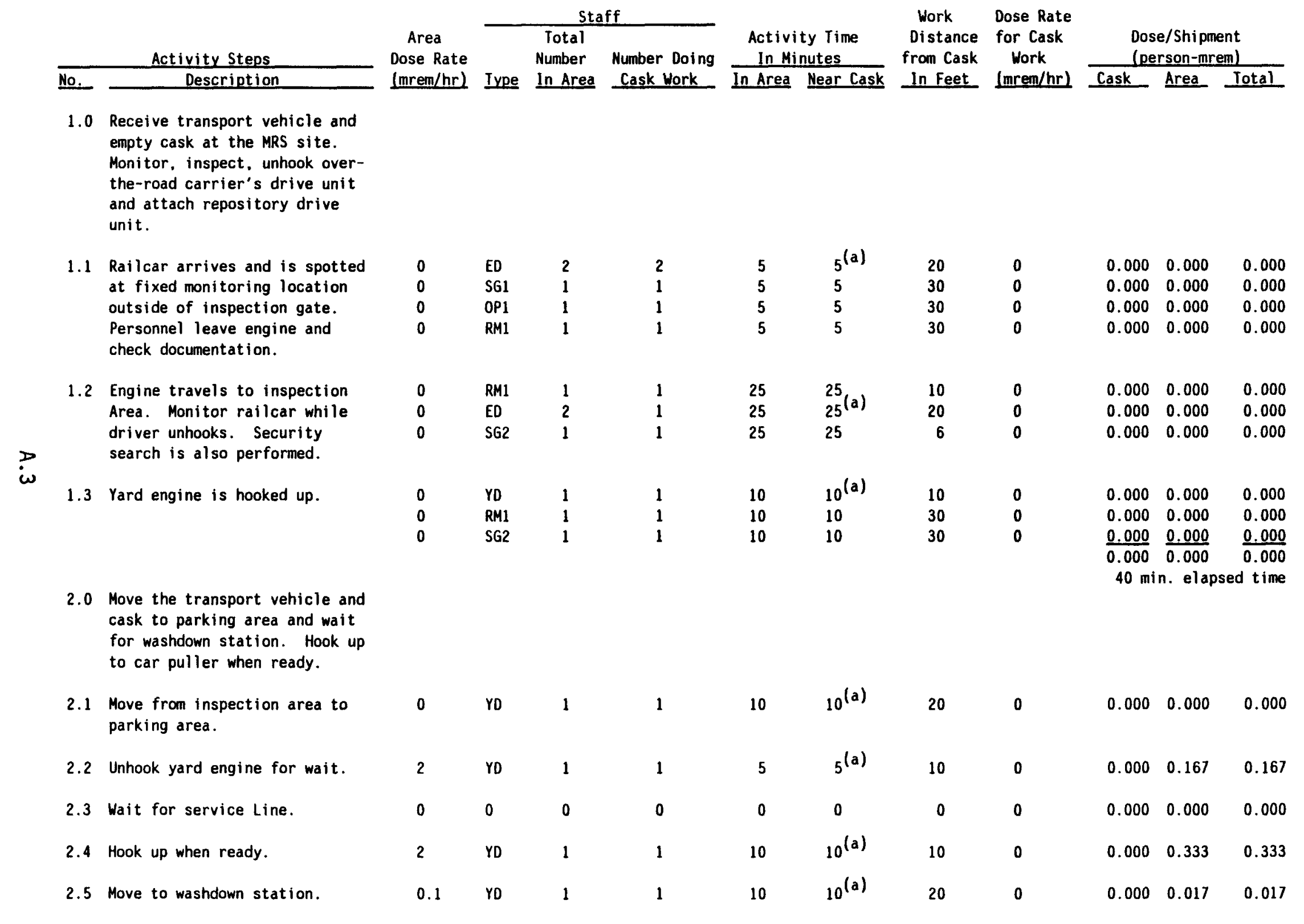




\begin{tabular}{|c|c|c|c|c|c|c|c|c|c|c|c|c|}
\hline & \multirow{3}{*}{$\begin{array}{l}\text { Activity Steps } \\
\text { Description }\end{array}$} & \multirow{3}{*}{$\begin{array}{l}\text { Area } \\
\text { Dose Rate } \\
\text { (mrem/hr) }\end{array}$} & \multicolumn{3}{|c|}{ Staff } & \multirow{2}{*}{\multicolumn{2}{|c|}{$\begin{array}{l}\text { Activity Time } \\
\text { In Minutes }\end{array}$}} & \multirow{3}{*}{$\begin{array}{c}\text { Work } \\
\text { Distance } \\
\text { from Cask } \\
\text { In Feet } \\
\end{array}$} & \multirow{3}{*}{$\begin{array}{c}\text { Dose Rate } \\
\text { for Cask } \\
\text { Work } \\
\text { (mrem/hr) }\end{array}$} & \multirow{2}{*}{\multicolumn{3}{|c|}{$\begin{array}{l}\text { Dose/Shipment } \\
\text { (person-mrem) }\end{array}$}} \\
\hline & & & & \multirow{2}{*}{$\begin{array}{l}\text { Total } \\
\text { Number } \\
\text { In Area } \\
\end{array}$} & \multirow{2}{*}{$\begin{array}{l}\text { Number Doing } \\
\text { Cask Work }\end{array}$} & & & & & & & \\
\hline №. & & & Iype & & & In Area & Near Cask & & & Cask & Area & Iotal \\
\hline \multirow[t]{2}{*}{2.6} & Hook up to car puller. & 0.1 & YD & 1 & 1 & 5 & $5^{(a)}$ & 10 & 0 & 0.000 & 0.008 & 0.008 \\
\hline & & 0.1 & $M-C 1$ & 2 & 0 & 5 & 0 & & & $\frac{0.000}{0.000}$ & $\frac{0.017}{0.542}$ & $\frac{0.017}{0.542}$ \\
\hline 3.0 & $\begin{array}{l}\text { Wash transport vehicle and } \\
\text { cask, open personnel barrier, } \\
\text { monitor, inspect and dry. }\end{array}$ & & & & & & & & & & & \\
\hline \multirow[t]{2}{*}{3.1} & Manual washdown. & 0.1 & OP2 & 1 & 1 & 20 & $20^{(a)}$ & 6 & 0.1 & 0.033 & 0.033 & 0.067 \\
\hline & & 0.1 & $\mathrm{M}-\mathrm{Cl}$ & 2 & 0 & 20 & 0 & & & 0.000 & 0.067 & 0.067 \\
\hline \multirow[t]{4}{*}{3.2} & Retract personnel barrier. & 0.1 & $\mathrm{M}-\mathrm{Cl}$ & 2 & 2 & 10 & $10(a)$ & 3 & 0.2 & 0.067 & 0.033 & 0.100 \\
\hline & perform security inspection and & 0.1 & SG2 & 1 & 1 & 20 & $20^{(a)}$ & 6 & 0.1 & 0.033 & 0.033 & 0.067 \\
\hline & spot washdown of road dirt by & 0.1 & RM2 & 1 & 1 & 20 & 10 & 50 & 0 & 0.000 & 0.033 & 0.033 \\
\hline & $\begin{array}{l}\text { wand if necessary. Complete } \\
\text { radiation monitoring. drying. }\end{array}$ & 0.1 & $\mathrm{OP2}$ & 1 & 1 & 20 & 20 & 6 & 0.1 & 0.033 & 0.033 & 0.067 \\
\hline \multirow[t]{2}{*}{3.3} & Cask drying. & 0.1 & -- & 0 & 0 & 15 & $0^{(a)}$ & & 0 & 0.000 & $\underline{0.000}$ & $\underline{0.000}$ \\
\hline & & & & & & & & & & 0.167 & 0.233 & 0.400 \\
\hline 40 & & & & & & & & & & \multicolumn{3}{|c|}{55 min. elapsed time } \\
\hline 4.0 & to receiving and handling area. & & & & & & & & & & & \\
\hline \multirow[t]{2}{*}{4.1} & $\begin{array}{l}\text { Move to receiving and handling } \\
\text { area. }\end{array}$ & 0.1 & co & 1 & 1 & 5 & $5^{(a)}$ & 30 & 0 & $\frac{0.000}{0.000}$ & $\frac{0.008}{0.008}$ & $\frac{0.008}{0.008}$ \\
\hline & & & & & & & & & & \multicolumn{3}{|c|}{5 min. elapsed time } \\
\hline 5.0 & $\begin{array}{l}\text { Prepare cask for removal from } \\
\text { transport vehicle. }\end{array}$ & & & & & & & & & & & \\
\hline 5.1 & $\begin{array}{l}\text { Obtain and replace power hand } \\
\text { tools. }\end{array}$ & 0.1 & $M-C 1$ & 2 & 2 & 10 & $10^{(a)}$ & 20 & 0 & 0.000 & 0.033 & 0.033 \\
\hline \multirow[t]{2}{*}{5.2} & Retrieve hook and grapples with & 0.1 & $\mathrm{M}-\mathrm{Cl}$ & 2 & 2 & 10 & $10^{(a)}$ & 20 & 0 & 0.000 & 0.033 & 0.033 \\
\hline & $\begin{array}{l}\text { crane, connect to impact } \\
\text { limiter. }\end{array}$ & 0.1 & co & 1 & 1 & 10 & 10 & 30 & 0 & 0.000 & 0.017 & 0.017 \\
\hline \multirow[t]{3}{*}{5.3} & Remove impact limiters, rm & 0.1 & $\mathrm{M}-\mathrm{Cl}$ & 2 & 2 & 45 & $45^{(a)}$ & 3 & 0.2 & 0.300 & 0.150 & 0.450 \\
\hline & check, and place in setdown & 0.1 & RM2 & 1 & 1 & 45 & 5 & 10 & 0.1 & 0.008 & 0.075 & 0.083 \\
\hline & area (two trips required). & 0.1 & co & 1 & 1 & 45 & 45 & 30 & 0 & 0.000 & 0.075 & 0.075 \\
\hline
\end{tabular}




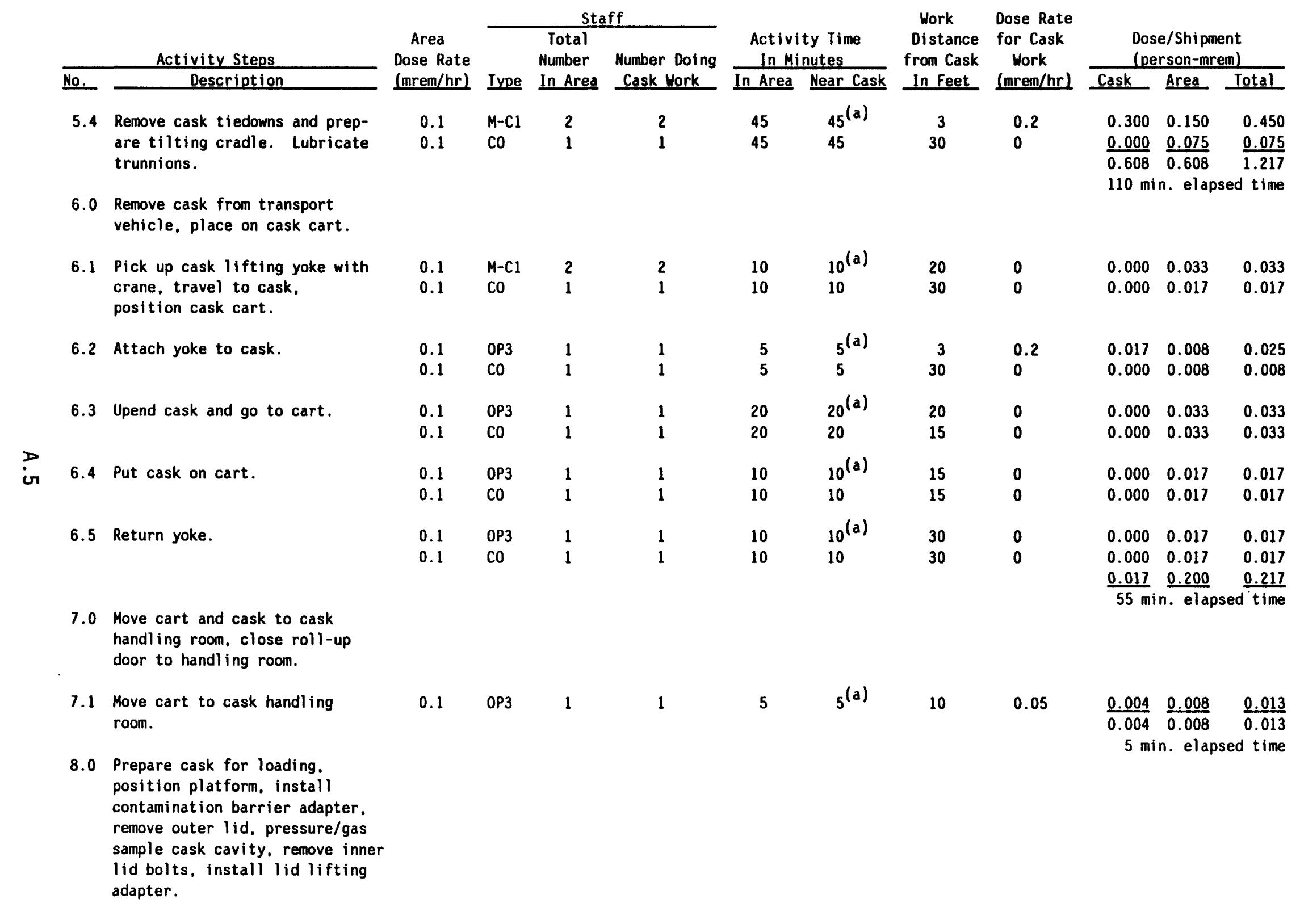




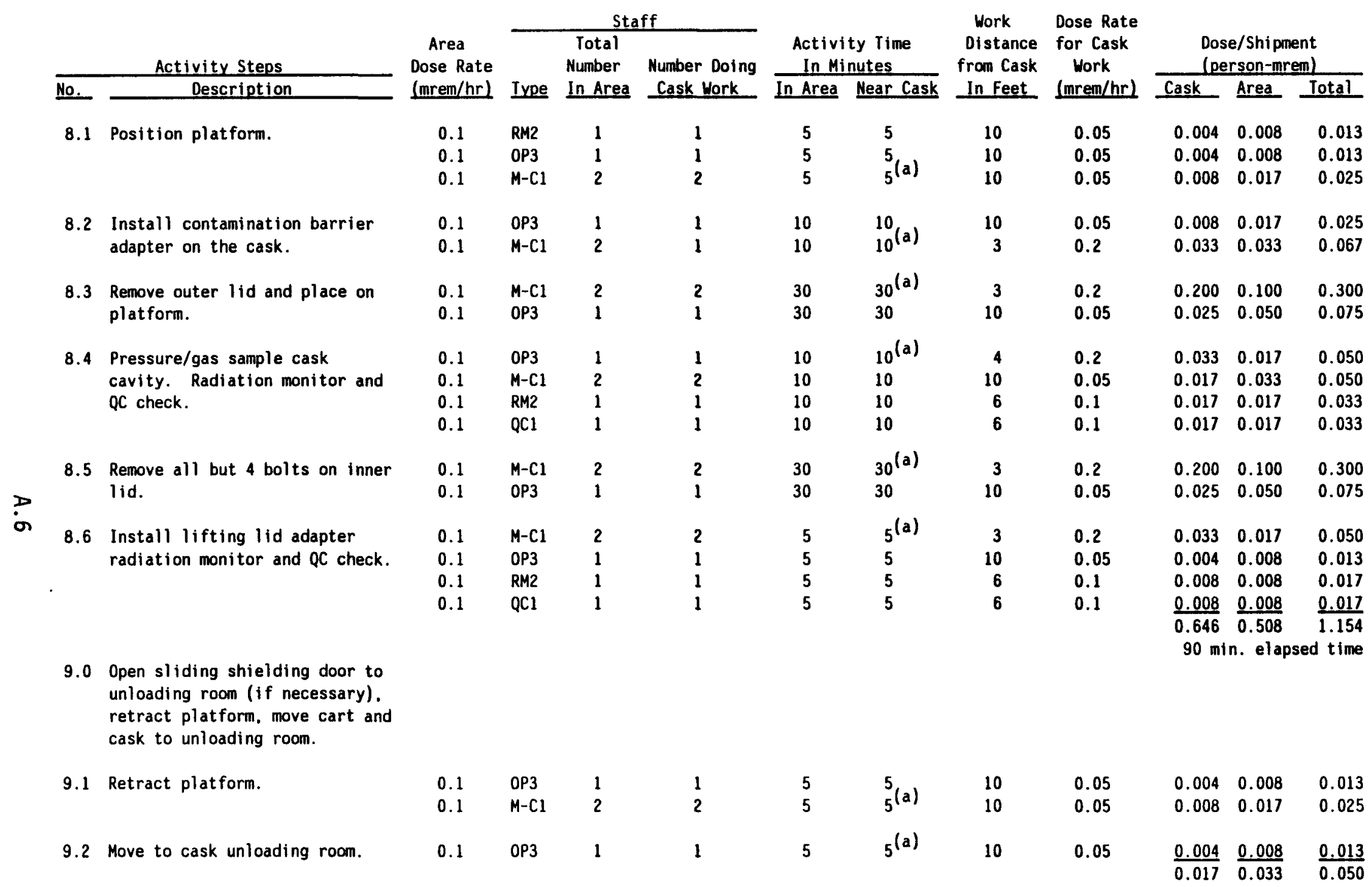

10.0 Mate the cask to the hot cell entry port. Close shielding door. 


\begin{tabular}{|c|c|c|c|c|c|c|c|c|c|c|c|c|}
\hline \multirow{2}{*}{\multicolumn{2}{|c|}{ Activity Steps }} & \multirow{3}{*}{$\begin{array}{l}\text { Area } \\
\text { Dose Rate } \\
\text { (mrem/hr) }\end{array}$} & \multicolumn{3}{|c|}{ Staff } & \multirow{2}{*}{\multicolumn{2}{|c|}{$\begin{array}{l}\text { Activity Time } \\
\text { In Minutes } \\
\end{array}$}} & \multirow{3}{*}{$\begin{array}{c}\text { Work } \\
\text { Distance } \\
\text { from Cask } \\
\text { In Feet } \\
\end{array}$} & \multirow{3}{*}{$\begin{array}{c}\text { Dose Rate } \\
\text { for Cask } \\
\text { Work } \\
\text { (mrem/hr) }\end{array}$} & \multirow{2}{*}{\multicolumn{3}{|c|}{$\begin{array}{r}\text { Dose/Shipment } \\
\text { (person-mrem) } \\
\end{array}$}} \\
\hline & & & & \multirow{2}{*}{$\begin{array}{l}\text { Total } \\
\text { Number } \\
\text { In Area } \\
\end{array}$} & \multirow{2}{*}{$\begin{array}{l}\text { Number Doing } \\
\text { Cask Hork } \\
\end{array}$} & & & & & & & \\
\hline No. & Description & & Iype & & & In Area & Near Cask & & & Cask & Area & Iotal \\
\hline 10.1 & $\begin{array}{l}\text { Mate cask to hot cell entry } \\
\text { port. }\end{array}$ & 0.1 & $O P 3$ & 1 & 1 & 5 & $5^{(a)}$ & 10 & 0.05 & 0.004 & 0.008 & 0.013 \\
\hline 10.2 & Close shadow shield. & 0.1 & $\mathrm{OP3}$ & 1 & 1 & 5 & $5^{(a)}$ & 10 & 0.05 & 0.004 & 0.008 & 0.013 \\
\hline 10.3 & Close shielding door. & 0.1 & $\mathrm{OP} 3$ & 1 & 1 & 5 & $5^{(a)}$ & 20 & 0 & $\frac{0.000}{0.008}$ & $\frac{0.008}{0.025}$ & $\frac{0.008}{0.033}$ \\
\hline 11.0 & $\begin{array}{l}\text { Using } 20 \text {-ton hot cell crane, } \\
\text { remove hot cell port plugs. }\end{array}$ & & & & & & & & & $15 \mathrm{mi}$ & n. elap & ed time \\
\hline 11.1 & $\begin{array}{l}\text { 20-ton crane picks up special } \\
\text { grapple. }\end{array}$ & 0.1 & Op4 & 2 & & 5 & $5^{(a)}$ & & & 0.000 & 0.017 & 0.017 \\
\hline 11.2 & $\begin{array}{l}\text { Remove port plugs and set } \\
\text { aside. }\end{array}$ & 0.1 & OP4 & 2 & & $20^{(a)}$ & & & & $\frac{0.000}{0.000}$ & $\frac{0.067}{0.083}$ & $\frac{0.067}{0.083}$ \\
\hline 12.0 & $\begin{array}{l}\text { Remove remaining inner lid } \\
\text { bolts. Remove inner lid and } \\
\text { spent fuel assembly spacer. }\end{array}$ & & & & & & & & & $25 \mathrm{mi}$ & n. elap & ied time \\
\hline 12.1 & $\begin{array}{l}\text { Replace grapple with tool for } \\
\text { bolt removal. }\end{array}$ & 0.1 & OP4 & 2 & & $5^{(a)}$ & & & & 0.000 & 0.017 & 0.017 \\
\hline 12.2 & Remove 4 bolts. & $\begin{array}{l}0.1 \\
0.1\end{array}$ & $\begin{array}{l}\text { OP4 } \\
\text { QC2 }\end{array}$ & $\begin{array}{l}2 \\
1\end{array}$ & & $\begin{array}{l}15^{(a)} \\
15\end{array}$ & & & & $\begin{array}{l}0.000 \\
0.000\end{array}$ & $\begin{array}{l}0.050 \\
0.025\end{array}$ & $\begin{array}{l}0.050 \\
0.025\end{array}$ \\
\hline 12.3 & $\begin{array}{l}\text { Replace bolt tool with lid } \\
\text { grapple. Remove lid, inspect. } \\
\text { and set aside. }\end{array}$ & $\begin{array}{l}0.1 \\
0.1\end{array}$ & $\begin{array}{l}\mathrm{OP4} \\
\mathrm{QC2}\end{array}$ & $\begin{array}{l}2 \\
1\end{array}$ & & $\begin{array}{l}15^{(a)} \\
15\end{array}$ & & & & $\begin{array}{l}0.000 \\
0.000\end{array}$ & $\begin{array}{l}0.050 \\
0.025\end{array}$ & $\begin{array}{l}0.050 \\
0.025\end{array}$ \\
\hline 12.4 & $\begin{array}{l}\text { Replace grapple for spent fuel, } \\
\text { remove fuel spacer. }\end{array}$ & $\begin{array}{l}0.1 \\
0.1\end{array}$ & $\begin{array}{l}\text { OP4 } \\
\text { OC2 }\end{array}$ & $\begin{array}{l}2 \\
1\end{array}$ & & $\begin{array}{l}15^{(a)} \\
15\end{array}$ & & & & $\begin{array}{r}0.000 \\
0.000 \\
0.000 \\
50 \mathrm{mi}\end{array}$ & $\begin{array}{l}0.050 \\
0.025 \\
0.242 \\
\text { n. elap }\end{array}$ & $\begin{array}{r}0.050 \\
0.025 \\
0.242 \\
\text { ed time }\end{array}$ \\
\hline
\end{tabular}




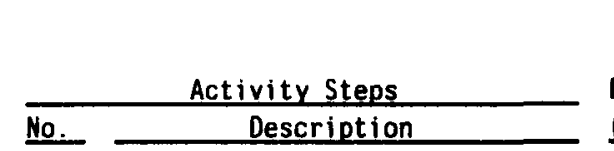

13.1 Load csf canisters into cask after visually inspecting (15 min./canister).

14.0 Monitor and vacuum cask cavity and fuel basket.

15.0 Replace spent fuel assembly spacer. Replace inner lid hot cell port plugs.

15.1 Exchange inspection tool for fuel spacer/lid grapple.

15.2 Replace fuel spacer and Iid.

15.3 Exchange fuel spacer/lid grapple for lid bolt tool.

15.4 Install four bolts.

15.5 Replace lid bolt tool with plug grapple.

15.6 Replace entry port plugs.

16.0 Unmate cask from hot cell port. Open unloading room shielding door.

16.1 Open shielding door.

16.2 Raise shadow shield.

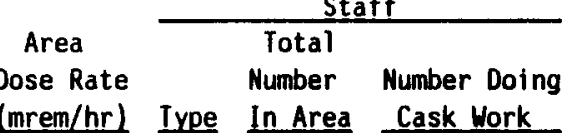

$\begin{array}{lll}0.1 & O P 4 & 2 \\ 0.1 & \text { QC2 } & 1\end{array}$

(ACTIVITY NOT PERFORMEO)
Work Dose Rate

Activity Time

Distance for Cask

from Cask Work

In Area Near Cask In Feet (mrem/hr)

$420^{(a)}$

420

$\begin{array}{lll}0.000 & 1.400 & 1.400 \\ 0.000 & 0.700 & 0.700\end{array}$

$0.000 \quad 2.100 \quad 2.100$

$420 \mathrm{~min}$. elapsed time

$5^{(a)}$

5

$30^{(a)}$

30

$5^{\text {(a) }}$

$15^{\text {(a) }}$

15

$5^{(a)}$

$20^{(a)}$

20

\begin{tabular}{lll}
0.000 & 0.017 & 0.017 \\
0.000 & 0.008 & 0.008 \\
0.000 & 0.100 & 0.100 \\
0.000 & 0.050 & 0.050 \\
& & \\
0.000 & 0.017 & 0.017 \\
0.000 & 0.008 & 0.008 \\
& & \\
0.000 & 0.050 & 0.050 \\
0.000 & 0.025 & 0.025 \\
& & \\
0.000 & 0.017 & 0.017 \\
0.000 & 0.008 & 0.008 \\
& & \\
0.000 & 0.067 & 0.067 \\
0.000 & $\underline{0.033}$ & $\underline{0.033}$ \\
\hline 0.000 & 0.400 & 0.400 \\
80 min. elapsed time
\end{tabular}

$80 \mathrm{~min}$. elapsed time
0.
OP3

$\begin{array}{ll}5 & 5^{(a)} \\ 5 & 5^{(a)}\end{array}$

20

5
$0.167 \quad 0.008$

0.175

$\begin{array}{lll}0.417 & 0.008 & 0.425\end{array}$ 


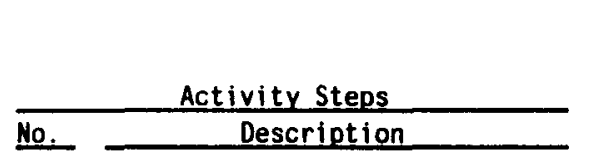

16.3 Release contamination barrier.

17.0 Move cart and cask to handling room.

17.1 Move to handling room.

18.0 Install platform. Remove contamination barrier and lifting adapter. Install inner and outer lids. Secure all openings to the cask. Monitor and decontaminate exterior of cask. Open roll-up door. Retract platform.

18.1 Install platform and remove contamination barrier, adapter.

18.2 Monitor and decontaminate external of cask as required.

OP3

Staff

Number Number Doing

Dose Rate (mrem/hr)

$$
0.1
$$

OP3

1

1

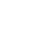

(2)

In Minutes Area Mear Cas

$5^{(a)}$

Work

from Cask for Cask

In Feet (mrem/hr)

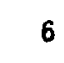

6

10

$\begin{array}{lll}\frac{0.833}{1.417} & \frac{0.008}{0.025} \quad \frac{0.842}{1.442} \\ 15 \text { min. elapsed time }\end{array}$

${ }_{5}^{(a)}$

10

5

\section{$\frac{0.417}{0.417} \quad \frac{0.008}{0.008} \quad \frac{0.425}{0.425}$}

5 min. elapsed time

18.3 Remove lifting lid adapter.

18.4 Install inner lid bolts and verify torque.

18.5 Secure all sample, flush, and drain ports.

\begin{tabular}{|c|c|c|c|c|}
\hline OP3 & 1 & 1 & 15 & 15 \\
\hline RM2 & 1 & 1 & 15 & 15 (a) \\
\hline $\mathrm{M}-\mathrm{Cl}$ & 2 & 2 & 15 & $15^{(a)}$ \\
\hline RM2 & 1 & 1 & 40 & ${ }_{40}(\mathrm{a})$ \\
\hline$M-C 1$ & 2 & 2 & 40 & 40 \\
\hline OP3 & 1 & 1 & 40 & 40 \\
\hline $\mathrm{M}-\mathrm{Cl}$ & 2 & 2 & 5 & $5^{(a)}$ \\
\hline $\mathrm{OP3}$ & 1 & 1 & 5 & 5 \\
\hline RM2 & 1 & 1 & 5 & 5 \\
\hline $\mathrm{M}-\mathrm{Cl}$ & 2 & 2 & 30 & $30^{(a)}$ \\
\hline OP3 & 1 & 1 & 30 & 30 \\
\hline$Q C 1$ & 1 & 1 & 30 & 30 \\
\hline 0P3 & 1 & 1 & 10 & $10^{(a)}$ \\
\hline $\mathrm{M}-\mathrm{Cl}$ & 2 & 2 & 10 & 10 \\
\hline RM2 & 1 & 1 & 10 & 10 \\
\hline
\end{tabular}

$\begin{array}{rrr}1.250 & 0.025 & 1.275 \\ 1.250 & 0.025 & 1.275 \\ 2.500 & 0.050 & 2.550 \\ & & \\ 20.000 & 0.067 & 20.067 \\ 6.667 & 0.133 & 6.800 \\ 20.000 & 0.067 & 20.067 \\ & & \\ 33.333 & 0.017 & 33.350 \\ 0.417 & 0.008 & 0.425 \\ 0.417 & 0.008 & 0.425 \\ & & \\ 200.000 & 0.100 & 200.100 \\ 2.500 & 0.050 & 2.550 \\ 2.500 & 0.050 & 2.550 \\ & & \\ 16.667 & 0.017 & 16.683 \\ 1.667 & 0.033 & 1.700 \\ 1.667 & 0.017 & 1.683\end{array}$




\begin{tabular}{|c|c|c|c|c|c|c|c|c|c|c|c|c|}
\hline \multirow{2}{*}{\multicolumn{2}{|c|}{ Activity Steps }} & \multirow{3}{*}{$\begin{array}{l}\text { Area } \\
\text { Dose Rate } \\
\text { (mrem/hr) }\end{array}$} & \multicolumn{3}{|c|}{ Staff } & \multirow{2}{*}{\multicolumn{2}{|c|}{$\begin{array}{l}\text { Activity Time } \\
\text { In Minutes }\end{array}$}} & \multirow{3}{*}{$\begin{array}{c}\text { Work } \\
\text { Distance } \\
\text { from Cask } \\
\text { In Feet }\end{array}$} & \multirow{3}{*}{$\begin{array}{l}\text { Dose Rate } \\
\text { for Cask } \\
\text { Work } \\
\text { (mrem/hr) }\end{array}$} & \multirow{2}{*}{\multicolumn{3}{|c|}{$\begin{array}{l}\text { Dose/Shipment } \\
\text { (person-mrem) }\end{array}$}} \\
\hline & & & & \multirow{2}{*}{$\begin{array}{l}\text { Total } \\
\text { Number } \\
\text { In Area }\end{array}$} & \multirow{2}{*}{$\begin{array}{l}\text { Number Doing } \\
\text { Cask Nork } \\
\end{array}$} & & & & & & & \\
\hline No. & Description & & Iype & & & In Area & Near Cask & & & Cask & Area & Total \\
\hline \multirow[t]{3}{*}{18.6} & Install outer lid and verify & 0.1 & $\mathrm{M}-\mathrm{Cl}$ & 2 & 2 & 30 & $30^{(a)}$ & 3 & 80 & 80.000 & 0.100 & 80.100 \\
\hline & torque. & 0.1 & OP3 & 1 & 1 & 30 & 30 & 10 & 5 & 2.500 & 0.050 & 2.550 \\
\hline & & 0.1 & QC1 & 1 & 1 & 30 & 30 & 5 & 10 & 5.000 & 0.050 & 5.050 \\
\hline \multirow[t]{3}{*}{18.7} & Remove platform. & 0.1 & OP3 & 1 & 1 & 5 & $5^{(a)}$ & 10 & 5 & 0.417 & 0.008 & 0.425 \\
\hline & & 0.1 & $\mathrm{M}-\mathrm{Cl}$ & 2 & 2 & 5 & 5 & 10 & 5 & $\frac{0.833}{399.583}$ & $\frac{0.017}{0.892}$ & $\frac{0.850}{400.475}$ \\
\hline & & & & & & & & & & $135 \mathrm{~min}$. & elapse & time \\
\hline
\end{tabular}

19.0 Move cask and cart to

receiving and handling area.

19.1 Move cart to receiving and inspection area.

$0.1 \quad 0 P 3 \quad 1$

20.0 Place cask on the transport

is vehicle.

20.1 Pick up cask lifting yoke with crane. travel to cask.

\begin{tabular}{|c|c|c|c|c|c|}
\hline 0.1 & $\mathrm{M}-\mathrm{Cl}$ & 1 & 1 & 10 & ${ }_{10}(a)$ \\
\hline 0.1 & CO & 1 & 1 & 10 & 10 \\
\hline 0.1 & $0 P 3$ & 1 & 1 & 5 & $5^{(a)}$ \\
\hline 0.1 & $\mathrm{CO}$ & 1 & 1 & 5 & 5 \\
\hline 0.1 & $0 P 3$ & 1 & 1 & 10 & $5^{(a)}$ \\
\hline 0.1 & $\mathrm{CO}$ & 1 & 1 & 10 & 10 \\
\hline 0.1 & OP3 & 1 & 1 & 5 & $5^{(a)}$ \\
\hline 0.1 & CO & 1 & 1 & 5 & 5 \\
\hline 0.1 & OP3 & 1 & 1 & 20 & ${ }_{20}(\mathrm{a})$ \\
\hline 0.1 & $\mathrm{CO}$ & 1 & 1 & 20 & 20 \\
\hline
\end{tabular}

21.0 Prepare cask for shipment Install cask tiedowns and impact limiters. Close personnel barrier. 


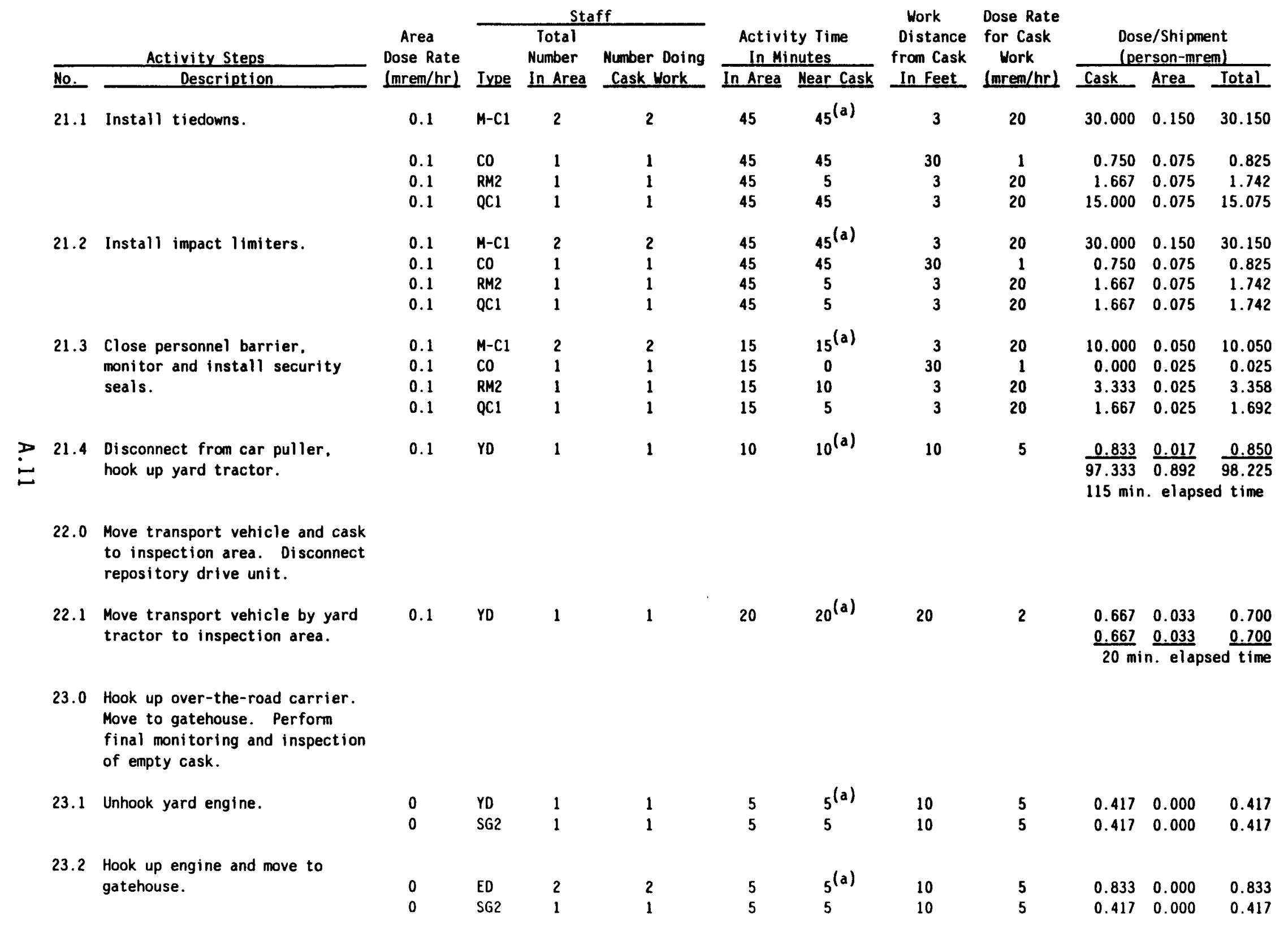




\begin{tabular}{|c|c|c|c|c|c|c|c|c|c|c|c|c|}
\hline & \multirow{3}{*}{$\begin{array}{c}\text { Area } \\
\text { Dose Rate } \\
\text { (mrem/hr) }\end{array}$} & \multicolumn{3}{|c|}{ Staff } & \multirow{2}{*}{\multicolumn{2}{|c|}{$\begin{array}{l}\text { Activity Time } \\
\text { In Minutes }\end{array}$}} & \multirow{3}{*}{$\begin{array}{l}\text { Work } \\
\text { Distance } \\
\text { from Cask } \\
\text { In Feet } \\
\end{array}$} & \multirow{3}{*}{$\begin{array}{l}\text { Dose Rate } \\
\text { for Cask } \\
\text { Work } \\
\text { (mrem/hr) }\end{array}$} & \multirow{2}{*}{\multicolumn{3}{|c|}{$\begin{array}{l}\text { Dose/Shipment } \\
\text { (person-mren) }\end{array}$}} \\
\hline & & & \multirow[b]{2}{*}{ Type } & \multirow{2}{*}{$\begin{array}{l}\text { Total } \\
\text { Number } \\
\text { In Area } \\
\end{array}$} & \multirow{2}{*}{$\begin{array}{l}\text { Number Doing } \\
\text { Cask Vork } \\
\end{array}$} & & & & & & & \\
\hline \multicolumn{2}{|c|}{$\frac{\text { Activity Steps }}{\text { No. }} \frac{\text { Description }}{\text { No. }}$} & & & & & In Area & Near Cask & & & Cask & Area & Iotal \\
\hline \multirow[t]{5}{*}{23.3} & \multirow{5}{*}{$\begin{array}{l}\text { Final monitoring and } \\
\text { inspection. }\end{array}$} & 0 & ED & 2 & 2 & 25 & $25(-)$ & 10 & 2 & 1.667 & 0.666 & 1.667 \\
\hline & & $\theta$ & RMI & 1 & 1 & 25 & $25^{(a)}$ & 3 & 20 & 8.333 & 8.660 & 8.333 \\
\hline & & 0 & OP1 & 1 & 1 & 25 & 25 & 3 & 2 & 9.833 & 8.608 & 6.833 \\
\hline & & $\theta$ & SG1 & 1 & 1 & 25 & 25 & 3 & 2 & $\frac{9.833}{13.750}$ & $\frac{9.686}{0.660}$ & $\frac{0.833}{13.750}$ \\
\hline & & & & & & & & & & $35 \mathrm{~m}$ in & . elaps & dime \\
\hline
\end{tabular}

24.8 Notify appropriate organizations of the shipment departure.

24.1 Not Ify organizations of shipment release - no exposure expected.

(a) Indicates critical activity that controls the elapsed time of that activity. 
APPENDIX B

TIME/DISTANCE/DOSE CALCULATIONS FOR 150-TON CASK HANDLING AT THE REPOSITORY 


\section{APPENDIX B}

\section{IIME/DISTANCE/DOSE CALCULATIONS FOR 150-TON CASK HANDLING AT THE REPOSITORY}

This appendix contains the detailed spreadsheet used to calculate the radiation doses received by repository facility workers during the operations of receiving a loaded cask from the MRS, unloading the cask containing spent fuel and/or packaged NFBC, and preparing the empty cask for a return shipment to the MRS facility.

The time steps, dose rates, and staffing levels involved in the cask handling operations are, for the most part, identical with those developed in the appendixes to DOE (1987a). Some small changes have been made, where appropriate, to reflect the longer time required to unload the larger-capacity cask.

The operations and doses shown in the spreadsheet represent those necessary for processing a single 150-ton rail cask through the repository surface facility. to calculate the annual doses to the facility staff, the doses resulting from operations on a single cask must be multiplied by the number of casks handled by the staff during a year.

Twenty-four major activities have been identified for the processing of a cask through the repository. Each of those activities has a number of individual steps within it to accomplish its purpose. The attached spreadsheet contains all of ten activities and all of ten steps within each activity, the types and number of staff involved in each step, the time duration of exposure to radiation, and the radiation dose rate during that exposure period, for each staff member. The radiation dose to each staff member during each step is computed as the product of (the time in radiation field) $x$ (dose rate in the radiation field). There are two components of this calculation, one for the dose rate and time of exposure in the general work area and one for the dose rate and time of exposure in the immediate vicinity of the cask. The two components are summed to provide the total dose to a worker resulting from a given step in an activity. 
The types and numbers of staff required to carry out the cask handling activities and the doses associated with those activities are given in Table B.l.

There is one other category of workers shown in the spreadsheets, an engine driver (ED). This category is part of the transportation worker population, not of the facility worker population. Thus, the doses received by these workers during operations at the repository fall into the transport worker totals. While the number of individuals involved in the at-facility transportation operations is not well-defined, the dose per cask is available from the spreadsheet: Engine Driver (rail) $1.166 \mathrm{mrem} /$ cask. Thus, the cumulative annual dose to this worker category can be calculated, knowing the annual number of casks passing through the facilities.

TABLE B.1. Types and Numbers of Staff Required for 150-Ton Cask Handling Operations at the Repository

\section{Type of Staff}

Radiation Monitor (RM1, RM2)

Security Guard (SG1, SG2)

Facility Operator (OP1, OP2, OP3, OP4)

Maintenance-Craftsmen ( $M C 1)$

Quality Technician (QC1, QC2)

Yard Engine Driver (YD)

Crane Operator (CO)

Total Dose per Cask

$\begin{array}{cr}\begin{array}{c}\text { Number of Staff } \\ \text { per Type }\end{array} & \begin{array}{r}\text { Dose per Cask } \\ \text { (mrem/cask) }\end{array} \\ 10 & 6.358 \\ 8 & 5.700 \\ 43 & 37.634 \\ 24 & 388.000 \\ 12 & 4.024 \\ 4 & 1.766 \\ 6 & 3.655 \\ & 447.137\end{array}$




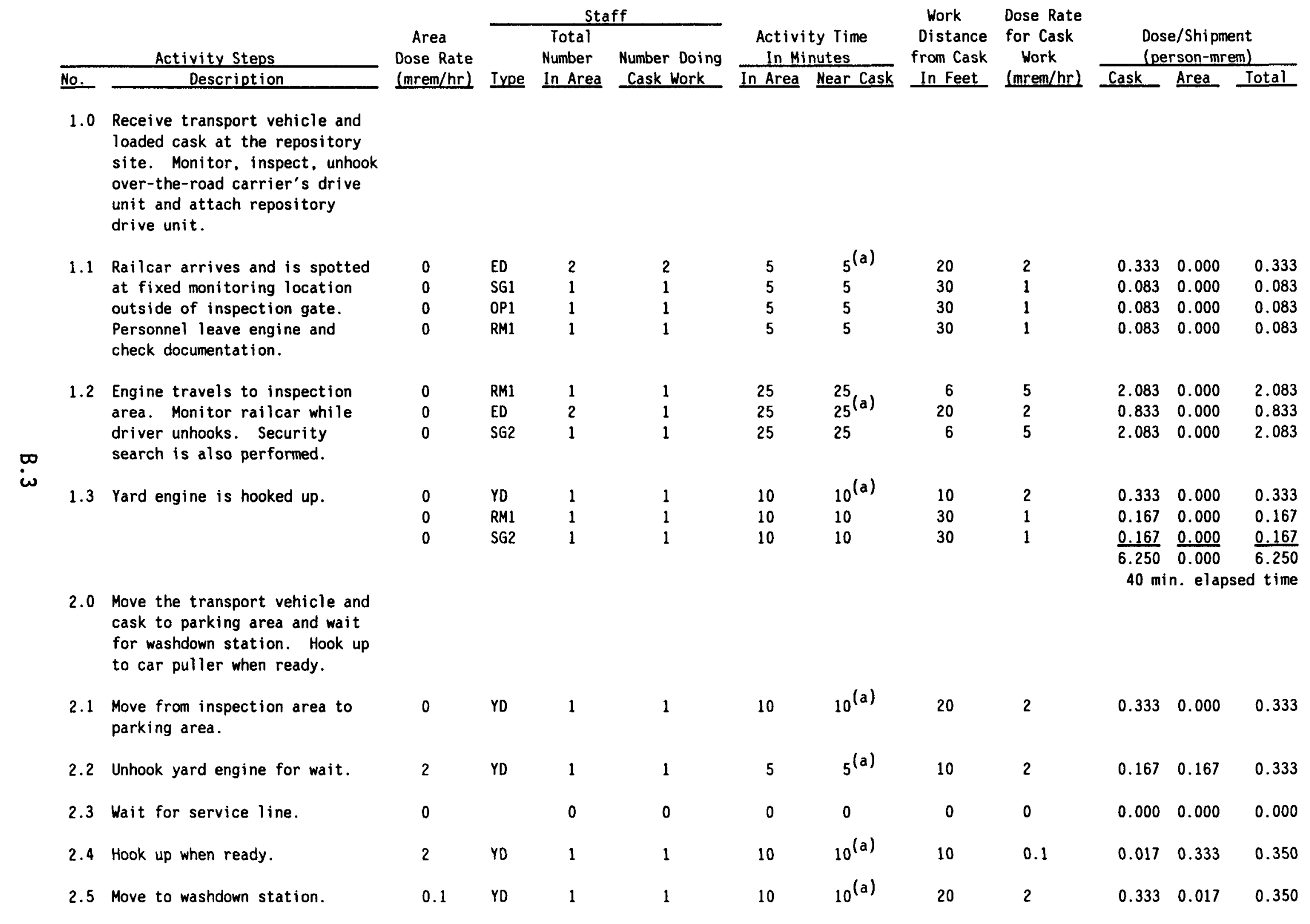




\begin{tabular}{|c|c|c|c|c|c|c|c|c|c|c|c|c|}
\hline & & & & Sta & & & & Work & Dose Rate & & & \\
\hline & Activity Steps & $\begin{array}{c}\text { Area } \\
\text { Dose Rate }\end{array}$ & & $\begin{array}{l}\text { Total } \\
\text { Number }\end{array}$ & Number Doing & $\begin{array}{r}\text { Activi } \\
\text { In } \mathrm{Mi} \\
\end{array}$ & $\begin{array}{l}\text { ty Time } \\
\text { nutes }\end{array}$ & $\begin{array}{r}\text { Distance } \\
\text { from Cask }\end{array}$ & $\begin{array}{l}\text { for Cask } \\
\text { Work }\end{array}$ & & $\begin{array}{l}\text { e/Shipmel } \\
\text { rson-mre }\end{array}$ & \\
\hline No... & Description & & Iype & In Area & Cask Work & In Area & Near Cask & In Feet & & Cask & Area & Total \\
\hline 2.6 & Hook up to car puller. & $\begin{array}{l}0.1 \\
0.1\end{array}$ & $\begin{array}{l}Y D \\
M-C 1\end{array}$ & $\begin{array}{l}1 \\
2\end{array}$ & $\begin{array}{l}1 \\
0\end{array}$ & $\begin{array}{l}5 \\
5\end{array}$ & $\begin{array}{l}5^{(a)} \\
0\end{array}$ & 10 & 0.1 & $\begin{array}{l}0.008 \\
0.000 \\
0.858\end{array}$ & $\frac{0.008}{0.017}$ & $\begin{array}{r}0.017 \\
\frac{0.017}{1.400} \\
0\end{array}$ \\
\hline 3.0 & $\begin{array}{l}\text { Wash transport vehicle and } \\
\text { cask, open personnel barrier, } \\
\text { monitor. inspect and dry. }\end{array}$ & & & & & & & & & & & \\
\hline 3.1 & Manual washdown. & $\begin{array}{l}0.1 \\
0.1\end{array}$ & $\begin{array}{l}\mathrm{OP2} \\
\mathrm{M}-\mathrm{Cl}\end{array}$ & $\begin{array}{l}1 \\
2\end{array}$ & $\begin{array}{l}1 \\
2\end{array}$ & $\begin{array}{l}20 \\
20\end{array}$ & $\begin{array}{c}20^{(a)} \\
0\end{array}$ & 6 & 10 & $\begin{array}{l}3.333 \\
0.000\end{array}$ & $\begin{array}{l}0.033 \\
0.067\end{array}$ & $\begin{array}{l}3.367 \\
0.067\end{array}$ \\
\hline 3.2 & $\begin{array}{l}\text { Retract personnel barrier. } \\
\text { Perform security inspection }\end{array}$ & $\begin{array}{l}0.1 \\
0.1\end{array}$ & $\begin{array}{l}\mathrm{M}-\mathrm{C} 1 \\
\mathrm{SG} 2\end{array}$ & $\begin{array}{l}2 \\
1\end{array}$ & $\begin{array}{l}2 \\
1\end{array}$ & $\begin{array}{l}10 \\
20\end{array}$ & ${ }_{20}^{10}(\mathrm{a})$ & $\begin{array}{r}10 \\
6\end{array}$ & $\begin{array}{r}5 \\
10\end{array}$ & $\begin{array}{l}1.667 \\
3.333\end{array}$ & $\begin{array}{l}0.033 \\
0.033\end{array}$ & $\begin{array}{l}1.700 \\
3.367\end{array}$ \\
\hline & and spot washdown of road & 0.1 & RM2 & 1 & 1 & 20 & 10 & 50 & 0 & 0.000 & 0.033 & 0.033 \\
\hline & $\begin{array}{l}\text { dirt by wand if necessary. } \\
\text { Complete radiation monitor- } \\
\text { ing, drying. }\end{array}$ & 0.1 & OP2 & 1 & 1 & 20 & 20 & 6 & 10 & 3.333 & 0.033 & 3.367 \\
\hline 3.3 & Cask drying. & 0.1 & -- & 0 & 0 & 15 & $15^{(a)}$ & & 0 & $\frac{0.000}{11.667}$ & $\begin{array}{l}\frac{0.000}{0.233} \\
\text { elapse }\end{array}$ & $\frac{0.000}{11.900}$ \\
\hline 4.0 & $\begin{array}{l}\text { Move transport vehicle and } \\
\text { cask to receiving and } \\
\text { handl ing area. }\end{array}$ & & & & & & & & & & & \\
\hline 4.1 & $\begin{array}{l}\text { Move to receiving and } \\
\text { handl ing area. }\end{array}$ & 0.1 & co & 1 & 1 & 5 & $5^{(a)}$ & 30 & 1 & $\frac{0.083}{0.083}$ & $\frac{0.008}{0.008}$ & $\frac{0.092}{0.092}$ \\
\hline 5.0 & $\begin{array}{l}\text { Prepare cask for removal } \\
\text { from transport vehicle. }\end{array}$ & & & & & & & & & & n. elaps & ed time \\
\hline 5.1 & $\begin{array}{l}\text { Obtain and replace power } \\
\text { hand tools. }\end{array}$ & 0.1 & $\mathrm{M}-\mathrm{Cl}$ & 2 & 2 & 10 & $10^{(\mathrm{a})}$ & 20 & 2 & 0.667 & 0.033 & 0.700 \\
\hline
\end{tabular}




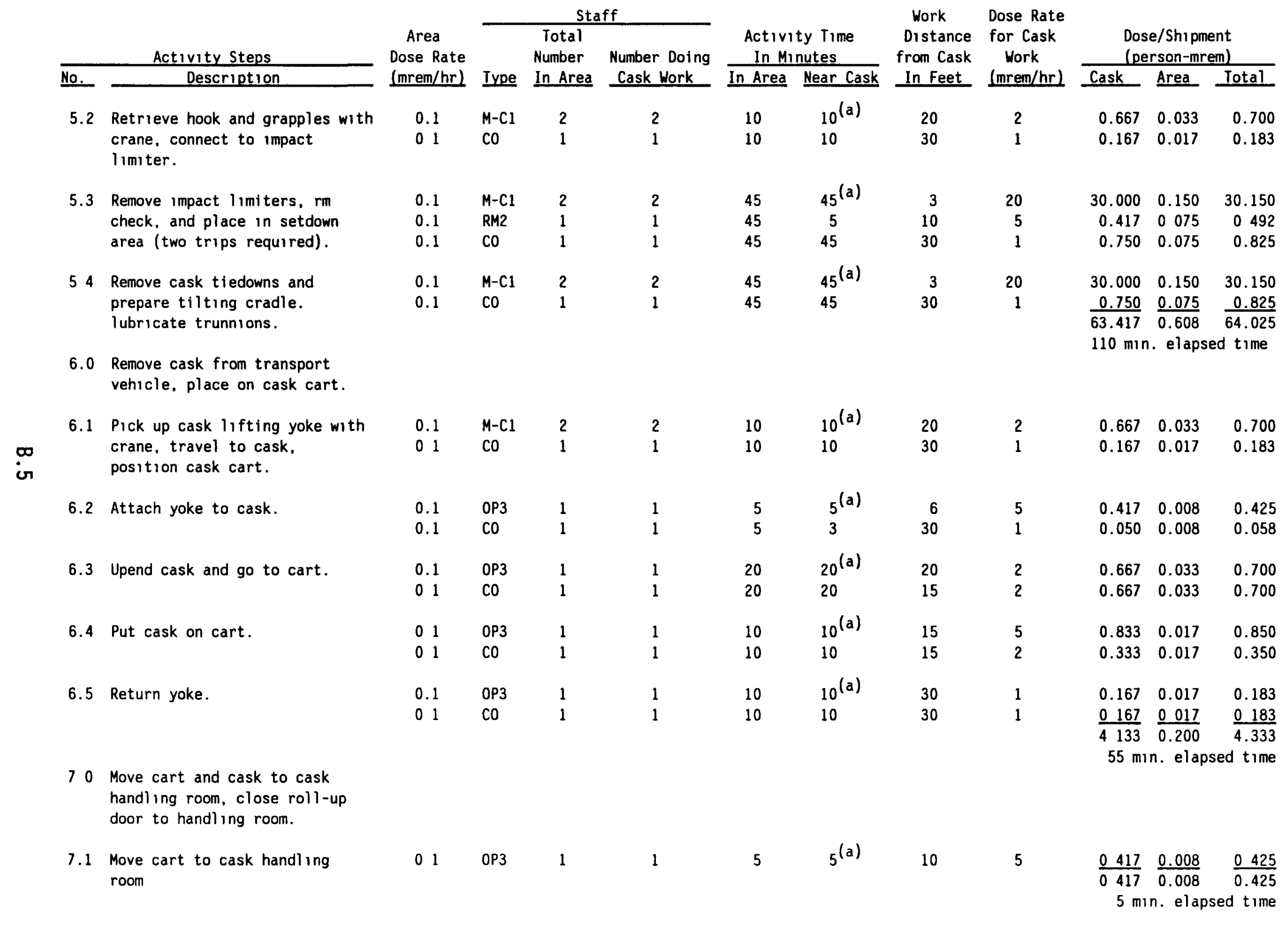




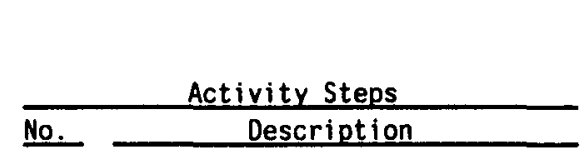

8.0 Prepare cask for unloading, position platform, install

contamination barrier adapter. remove outer lid, pressure/gas sample cask cavity, remove inner lid bolts, install lid lifting adapter.

8.1 Position platform.

8.2 Install contamination barrier adapter on the cask.

8.3 Remove outer lid and place on platform.

or

\subsection{Pressure/gas sample cask} cavity. Radiation monitor and QC check.

8.5 Remove all but 4 bolts on inner lid.

8.6 Install $1 \mathrm{ifting}$ lid adapter radiation monitor and $Q C$ check.

9.0 Open sliding shielding door to unloading room (if necessary). retract platform, move cart and cask to unloading room.

9.1 Retract platform.

\begin{tabular}{ccc} 
& \multicolumn{2}{c}{ Staff } \\
\cline { 2 - 3 } Area & Total \\
Dose Rate & Number Number Doing \\
(mrem/hr) Type In Area Cask Work
\end{tabular}

Activity Time

Work

Dose Rate

Distance for Cask Dose/Shipment

n Minutes

In Feet (mrem/hr) person-mrem
In Area Near Cask

Cask

Area Total 


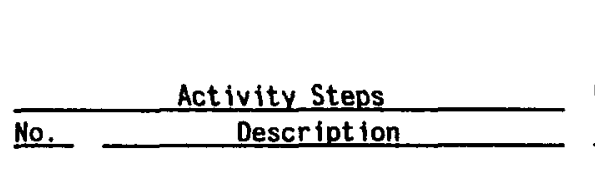

9.2 Move to cask unloading room.

10.0 Mate the cask to the hot cell entry port. Close shielding door.

10.1 Mate cask to hot cell entry port.

10.2 Close shadow shield.

16.3 Close shielding door.

11. Using 20-ton hot cell crane, remove hot cell port plugs.

11.120 -ton crane picks up special grapple.

11.2 Remove port plugs and set aside.

12.8 Remove remaining inner lid bolts. Remove Inner 1 id and spent fuel assembly spacer.

12.1 Replace grapple with tool for bolt removal.

12.2 Remove 4 bolts

12.3 Replace bolt tool with lid grapple. Remove lid, inspect, and set aside.

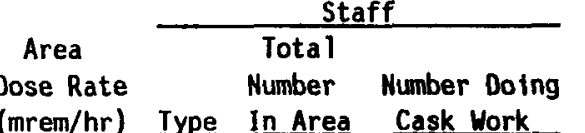

Activity Time

In Minutes

In Area Near Cask

Work Dose Rate

Distance for Cask

from Cask Work

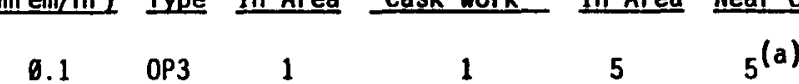

In Feet

mrem/hr)

\begin{tabular}{|c|c|c|}
\hline \multicolumn{3}{|c|}{$\begin{array}{l}\text { Dose/Shipment } \\
\text { (person-mrem) }\end{array}$} \\
\hline Cask & Area & Total \\
\hline 0.417 & 0.008 & 0.425 \\
\hline 1.667 & 0.833 & 1.700 \\
\hline
\end{tabular}

\begin{tabular}{|c|c|c|c|c|c|c|c|c|c|c|}
\hline 0.1 & $O P 3$ & 1 & 1 & 5 & $5^{(a)}$ & 10 & 5 & 0.417 & 0.068 & 6.425 \\
\hline 0.1 & $\mathrm{OP} 3$ & 1 & 1 & 5 & $5^{(a)}$ & 10 & 5 & 0.417 & 0.008 & 0.425 \\
\hline 0.1 & OP3 & 1 & 1 & 5 & $5^{(a)}$ & 20 & 2 & $\frac{0.167}{1.000}$ & $\frac{0.068}{0.025}$ & $\frac{0.175}{1.025}$ \\
\hline
\end{tabular}

$\begin{array}{llll}0.1 & \text { OP4 } & 2 & 5^{(a)} \\ 0.1 & 0 P 4 & 2 & 20^{(a)} \\ & & & \\ & & & \\ 0.1 & \text { OP4 } & 2 & 5^{(a)} \\ & & & \\ 0.1 & \text { OP4 } & 2 & 15^{(a)} \\ 0.1 & \text { QC2 } & 1 & 15 \\ 0.1 & \text { OP4 } & 2 & 15^{(a)} \\ 0.1 & \text { QC2 } & 1 & 15\end{array}$

$0.000 \quad 0.017 \quad 0.017$

$\frac{0.000}{0.0060} \quad \frac{0.067}{0.083} \quad \frac{0.067}{0.083}$ $25 \mathrm{~min}$. elapsed time

$0.000 \quad 0.017 \quad 0.017$

$0.000 \quad 0.050 \quad 0.050$

$0.000 \quad 0.025 \quad 0.025$

$0.000 \quad 0.050 \quad 0.050$

$0.000 \quad 0.025 \quad 0.025$ 


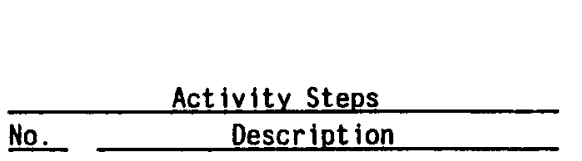

12.4 Replace grapple for spent fuel, remove fuel spacer.

13.0 Un load csf canisters and place into in-cell lag storage.

13.1 Un load csf canisters, place in lag storage after visually inspect ing (15 min/canister).

14.0 Monitor and vacuum cask cavity and fuel basket.

14.1 Replace grapple with vacuum device.

14.2 Vacuum cavities, Iid, fuel spacer.

14.3 Replace vacuum with survey tool. cavity and document.

14.5 Replace survey tool with inspection device and inspect.
14.4 Radiation survey of cask

Activity Time Dork Dose Rate

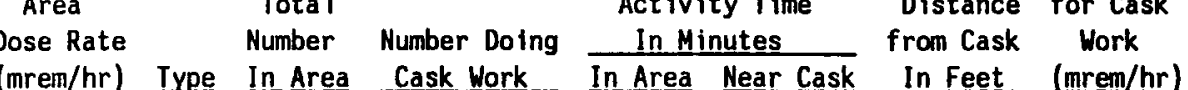

Dose/Shipment

$15^{(a)}$

$\begin{array}{llll}0.1 & \text { OP4 } & 2 & 15^{(a)} \\ 0.1 & \text { QC2 } & 1 & 15\end{array}$

$420(\mathrm{a})$

420

$0.1-0.12$

1004

0.1 QC2

$0.1 \quad 0 P 4$

6.1 QC2

$0.1 \quad 0 P 4$

0.1 QC2

b.1 OPA

0.1 QC2

15.0 Replace spent fuel assembly spacer. Replace inner lid hot cell port plugs.

15.1 Exchange inspection tool for fuel spacer/lid grapple.

15.2 Replace fuel spacer and lid.

$\begin{array}{llll}0.1 & \text { OP4 } & 2 & 5^{(a)} \\ 0.1 & \text { QC2 } & 1 & 5 \\ 0.1 & \text { OP4 } & 2 & 30^{(a)} \\ 0.1 & \text { QC2 } & 1 & 30\end{array}$

$$
5^{(a)}
$$$$
5
$$$$
20^{(a)}
$$$$
20
$$

5

$6 \theta^{(a)}$

60

${ }_{40}^{(a)}$

40

30

Cask Area Total

$0.600 \quad 0.650 \quad 0.050$

$0.060 \quad 0.025 \quad 0.025$

$0.600 \quad 0.242 \quad 0.242$

50 min. elapsed time

$.060 \quad 1.400 \quad 1.400$

$0.000 \quad 0.700 \quad 0.700$

$0.060 \quad \frac{0.700}{2.100} \quad \frac{0.709}{2.100}$

420 min. elapsed time

$0.060 \quad 0.017 \quad 0.017$

$0.000 \quad 0.008 \quad 0.008$

$0.060 \quad 0.667 \quad 0.067$

$0.060 \quad 0.033 \quad 0.033$

$0.000 \quad 0.017 \quad 0.017$

$0.660 \quad 0.068 \quad 0.098$

$0.000 \quad 0.200 \quad 0.200$

$0.600 \quad 0.100 \quad 0.100$

$0.006 \quad 0.133 \quad 0.133$

$0.060 \quad 0.067 \quad 0.067$

$0.000 \quad 0.650 \quad 0.650$

$130 \mathrm{~min}$. elapsed time

$\begin{array}{lll}0.000 & 0.017 & 0.017 \\ 0.000 & 0.068 & 0.098 \\ 0.000 & 0.100 & 0.100 \\ 0.000 & 0.050 & 0.050\end{array}$




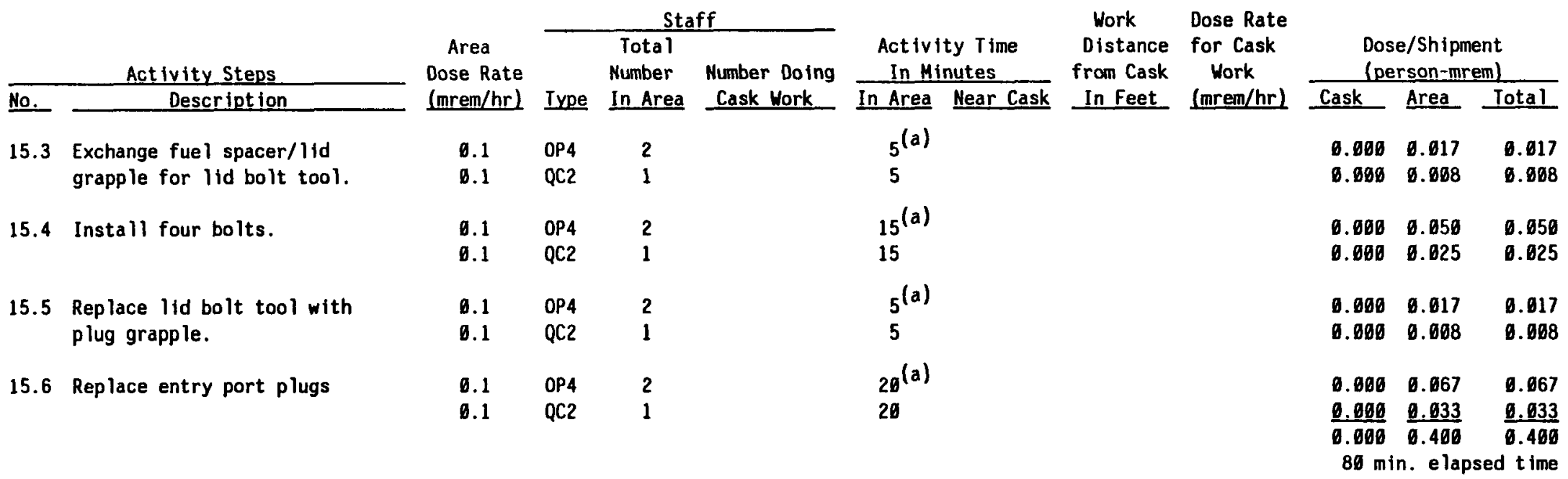

16. Unmate cask from hot cell port. Open unloading room shielding door.

16.2 Raise shadow shield

16.3 Release contamination barrier.

17.0 Move cart and cask to hand ling room.

17.1 Move to handling room.

18. Install platform. Remove contamination barrier and lifting adapter. Install inner and outer lids. Secure all openings to the cask. Monitor and decontaminate exterior of cask. Open rollup door. Retract platform.

\begin{tabular}{|c|c|c|c|c|c|c|c|c|c|c|}
\hline 0.1 & OP3 & 1 & 1 & 5 & $5^{(a)}$ & 20 & 0 & 0.000 & 0.068 & 0.008 \\
\hline 0.1 & $\mathrm{OP} 3$ & 1 & 1 & 5 & $5^{(a)}$ & 10 & 0 & 0.000 & 0.088 & 0.608 \\
\hline 0.1 & OP3 & 1 & 1 & 5 & $5^{(a)}$ & 6 & 0 & $\frac{0.000}{0.000}$ & $\frac{0.008}{0.625}$ & $\frac{0.008}{0.625}$ \\
\hline
\end{tabular}




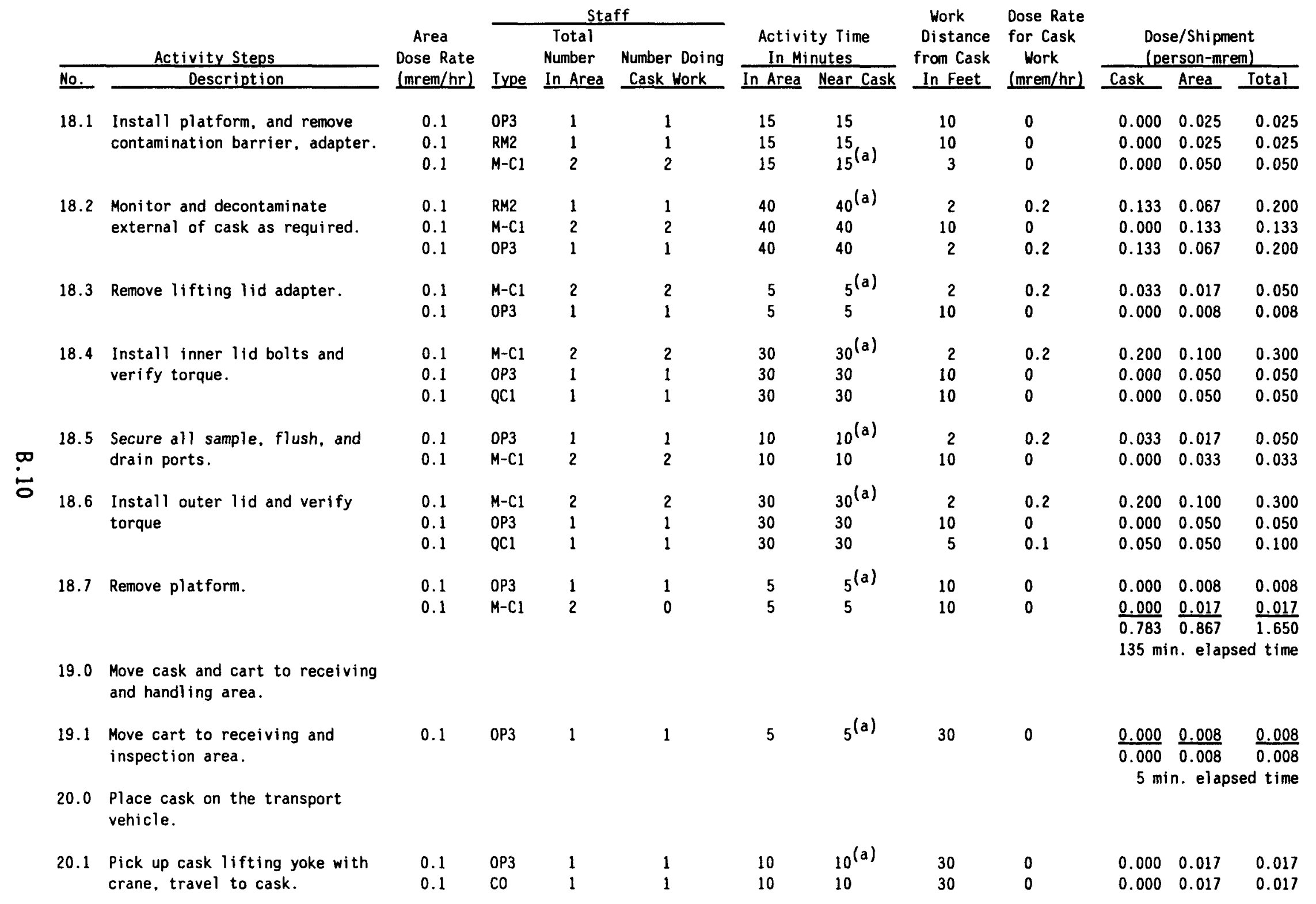




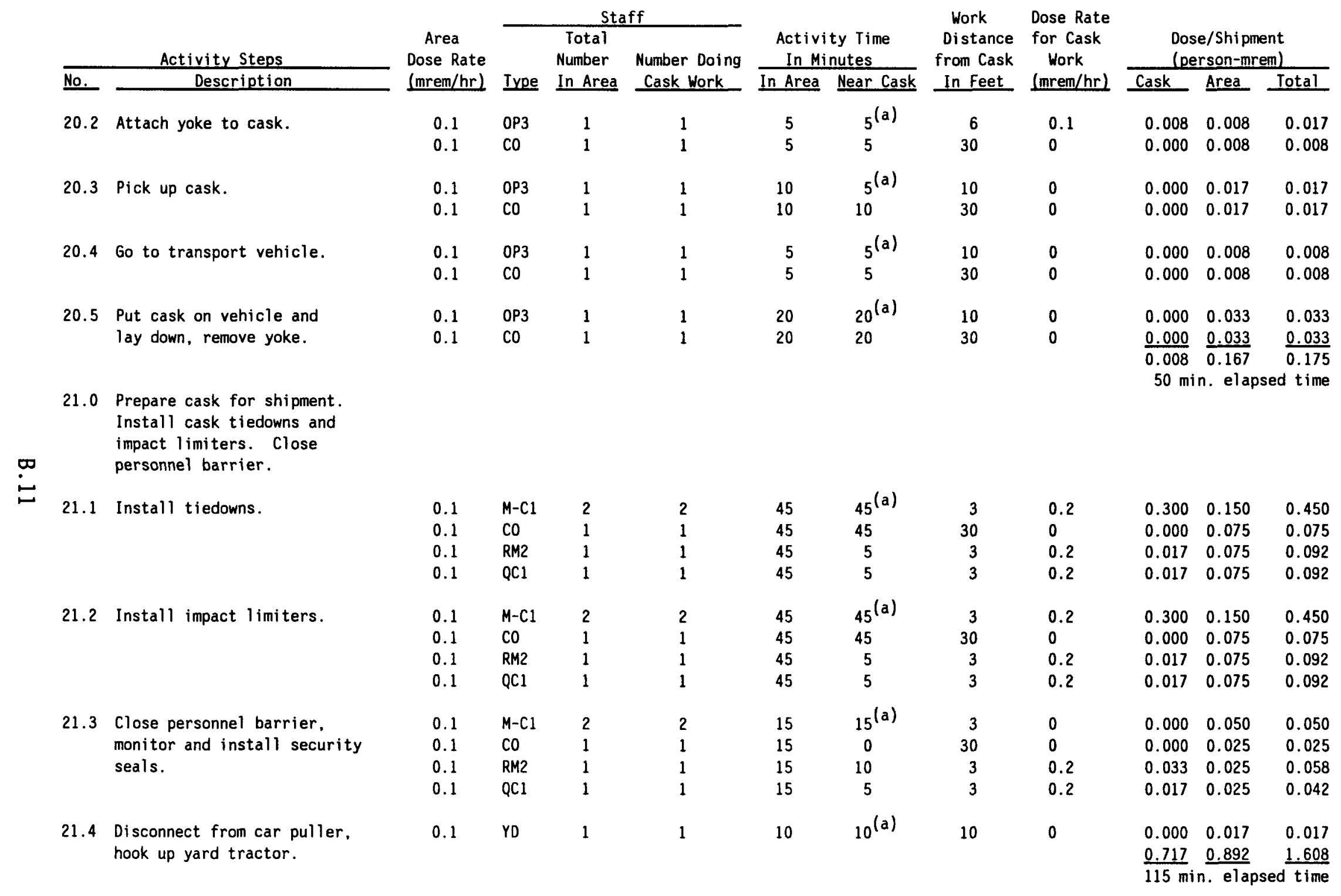




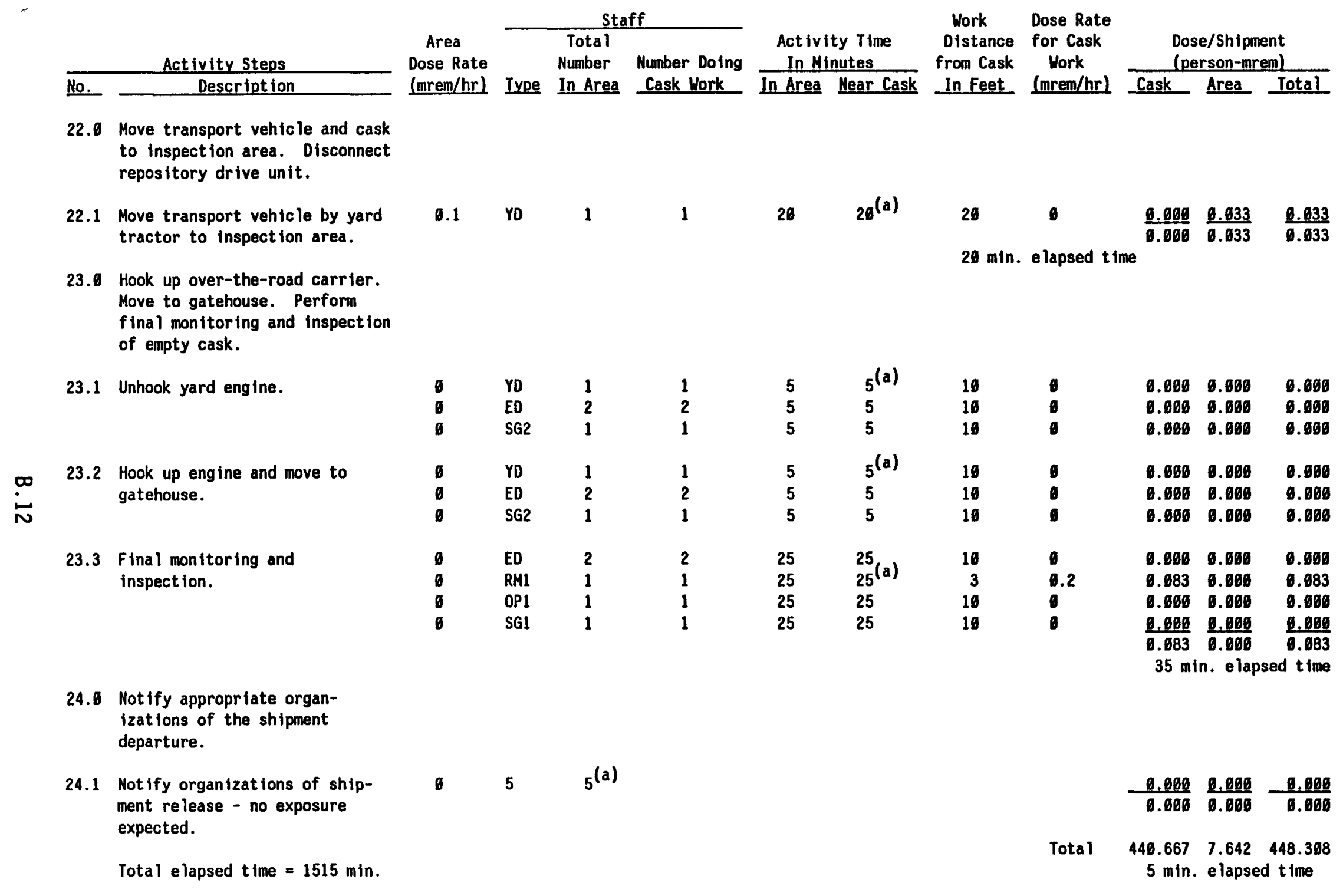

(a) Indicates critical activity that controls the elapsed time of that activity. 
APPENDIX C

IN-TRANSIT DOSE CALCULATIONS 
APPENDIX C

\section{IN-TRANSIT DOSE CALCULATIONS}

This appendix contains the detailed spreadsheets used to calculate intransit radiation doses to the public and workers. The exposure times, dose rates, and numbers of exposed persons are, for the most part, identical to those derived in DOE (1987a). The primary differences between DOE (1987a) and this analysis are:

- differences in shipping distances and number of shipments that arise from analyzing a system with an MRS vs. without an MRS

- the addition of a spreadsheet to calculate in-transit doses for dedicated train shipments.

This appendix presents the in-transit radiation dose calculations from 14 spreadsheets. There are seven spreadsheets for the different potential shipment types in a system with an eastern MRS and seven for the western MRS. The seven spreadsheets for each MRS location include truck and rail shipments from eastern reactors, truck and rail shipments from western reactors, and three potential dedicated train configurations for shipments from the MRS (one in which fuel is consolidated and the hardware is packaged in canisters, one in which the hardware is packaged in drums, and one in which the fuel is not consolidated). Two tables are provided for each potential shipment type: a table that contains the detailed spreadsheet and a summary table. Therefore, a total of 28 tables are presented in this appendix. These 28 tables are summarized as follows:

- Table C.1 Detailed, Truck from Eastern Reactors to an Eastern MRS

- Table C.2 Summary, Truck from Eastern Reactors to Eastern MRS

- Table C.3 Detailed, Truck from Eastern Reactors to Western MRS

- Table C.4 Summary, Truck from Eastern Reactors to Western MRS

- Table C.5 Detailed, Truck from Western Reactors to Repository

\section{C.1}


- Table C.6 Summary, Truck from Western Reactors to Repository

- Table C.7 Detailed, Truck from Western Reactors to Western MRS

- Table C.8 Summary, Truck from Western Reactors to Western MRS

- Table C.9 Detailed, GFR(a) from Eastern Reactors to Eastern MRS

- Table C.10 Summary, GFR from Eastern Reactors to Eastern MRS

- Table C.11 Detailed, GFR from Eastern Reactors to Western MRS

- Table C.12 Summary, GFR from Eastern Reactors to Western MRS

- Table C.13 Detailed, GFR from Western Reactors to Repository

- Table C.14 Summary, GFR from Western Reactors to Repository

- Table C.15 Detailed, GFR from Western Reactors to Western MRS

- Table C.16 Summary, GFR from Western Reactors to Western MRS

- Table C.17 Detailed, Dedicated Train Shipments, Consolidated Fuel, Hardware in Canisters (Eastern MRS)

- Table C.18 Summary, Dedicated Train, Consolidated Fue1, Hardware in Canisters (Eastern MRS)

- Table C.19 Detailed, Dedicated Train, Consolidated Fuel, Hardware in Drums (Eastern MRS)

- Table C.20 Summary, Dedicated Train, Consolidated Fuel, Hardware in Drums (Eastern MRS)

- Table C.21 Detailed, Dedicated Train, Unconsolidated Fuel (Eastern MRS)

- Table C.22 Summary, Dedicated Train, Unconsolidated Fuel (Eastern MRS)

- Table C.23 Detailed, Dedicated Train, Consolidated Fuel, Hardware in Canisters (Western MRS)

- Table C.24 Summary, Dedicated Train, Consolidated Fuel, Hardware in Canisters (Western MRS)

- Table C.25 Detailed, Dedicated Train, Consolidated Fuel, Hardware in Drums (Western MRS)

(a) GFR = General Freight Rail. 
- Table C.26 Summary, Dedicated Train, Consolidated Fuel, Hardware In Drums (Western MRS)

- Table C.27 Detailed, Dedicated Train, Unconsolidated Fuel (Western MRS)

- Table C.28 Summary, Dedicated Train, Unconsolidated Fuel (Western MRS) 
TABLE C.1. In-Transit Dose Calculations for Truck Shipments from Eastern Reactors to an Eastern MRS

INPUT DATA

Shipping Distance, $\mathrm{km}$

$\begin{array}{lr}\text { Rural } & 800.00 \\ \text { Suburban } & 500.00 \\ \text { Urban } & 13.00\end{array}$

\begin{tabular}{lrr} 
MTU/shipment & MTU/Yr \\
\hline PWR & 0.93 & 606.00
\end{tabular}

Total

3.00

Shipments $/ y r$

Average

Number of Distance From

Avtance from
Cask, m

Dose Rate, Exposure Dose Factor

mrem/hr Time hr Person-rem/km Distance

Subtotals, Per

Population Subgroup

Individuals

$\begin{array}{llll}10 & \text { Top } & 2.00 & 23.04 \\ 10 & \text { Top } & 0.60 & 7.22 \\ 20 & \text { Side } & 0.18 & 7.22\end{array}$

hipment Dose,

Drivers

- While moving

- At stops

Near cask

2.00

2.00

2.00

Side

0.18

7.22

92.17

Escorts

- While moving

In front

2.00

2.00

50

Top

0.02

0.54

Behind

4.00

50

Bottom

0.01

0.54

- At stops
Service Station Attendant

Near Cask

Away Cask

1.00

1.00
1.00

side

0.18

3.00

Top $\quad 0.60 \quad 0.67$

State Inspectors Near Cask

2.00
0.00

10

Top
side

0.18

2.33

Away Cask

5

side

3.20

2.00

8.67

$\frac{2.60}{11.27}$

General population

- While moving

Passing vehicles

Rural

Suburban

Urban

Population along route

Rural

Suburban

Urban

- At stops

TOTAL

$\begin{array}{rrr}3.10 E-06 & 800.00 & 2.48 \\ 4.00 E-05 & 500.00 & 20.00 \\ 1.40 E-04 & 13.00 & \frac{1.82}{24.30} \\ & & \\ 1.70 E-07 & 800.00 & 0.14 \\ 3.90 E-05 & 500.00 & 19.50 \\ 2.10 E-05 & 13.00 & \underline{0.27} \\ & & 19.91 \\ 1.40 E-04 & 1313.00 & 183.82\end{array}$

$\begin{array}{r}0.02 \\ 0.01 \\ \hline 0.03 \\ \frac{2.16}{2.19} \\ 0.40 \\ \frac{0.42}{0.82} \\ 12.80 \\ 0.00 \\ \hline 12.80 \\ \\ \\ 2.48 \\ 20.00 \\ 1.82 \\ \hline 24.30 \\ 0.14 \\ 19.50 \\ 0.27 \\ \hline 19.91 \\ 183.82 \\ \hline 346.45\end{array}$


TABLE C.2. Summary of Estimated In-Transit Radiation Doses for Truck Shipments from Eastern Reactors to an Eastern MRS

\begin{tabular}{|c|c|c|c|c|}
\hline \multirow[b]{2}{*}{ Population Subgroup } & \multicolumn{3}{|c|}{ Collective Dose (a) } & \multirow{2}{*}{$\begin{array}{l}\text { Dose to } \\
\text { Maximally Exposed } \\
\text { Individual, mrem } / y 1\end{array}$} \\
\hline & $\begin{array}{r}\text { Per-Shipment } \\
\text { Dose Person-mrem }\end{array}$ & $\begin{array}{l}\text { Person-prem } \\
\text { per MTU }(b)^{1}\end{array}$ & $\begin{array}{l}\text { Annual Dose, } \\
\text { Person-rem/yr }(c)\end{array}$ & \\
\hline $\begin{array}{l}\text { Transport Workers } \\
\text { - Drivers } \\
\text { - Escorts } \\
\text { - Attendants (d) } \\
\text { - Inspectors }\end{array}$ & $\begin{array}{r}103.43 \\
2.19 \\
0.82 \\
12.80 \\
\end{array}$ & $\begin{array}{r}111.70 \\
2.36 \\
0.89 \\
13.82 \\
\end{array}$ & $\begin{array}{r}88.69 \\
1.88 \\
0.70 \\
10.98 \\
\end{array}$ & $\begin{array}{r}2585.81 \\
117.76 \\
87.74 \\
684.80 \\
\end{array}$ \\
\hline $\begin{array}{l}\text { Tota1 Transport } \\
\text { Workers }\end{array}$ & 118.42 & 127.88 & 101.54 & NA \\
\hline Public & $\underline{228.03}$ & 246.25 & 195.52 & $57.78 / 2.43^{(\mathrm{e})}$ \\
\hline & Grand Total & 346.45 & 374.13 & 297.06 \\
\hline
\end{tabular}

NA = Not Applicable

(a) Columns may not sum correctly because of round-off.

(b) Based on 0.93 MTU PWR fuel per shipment.

(c) Based on annual shipment quantities given in Table C.1.

(d) Not included in totals.

(e) First value is the maximum public exposure at stops. The second value is the maximum public exposure to persons residing near the transport route. 
IABLE C.3. In-Transit Dose Calculations for Truck. Shipments from Eastern Reactors to a Western MRS

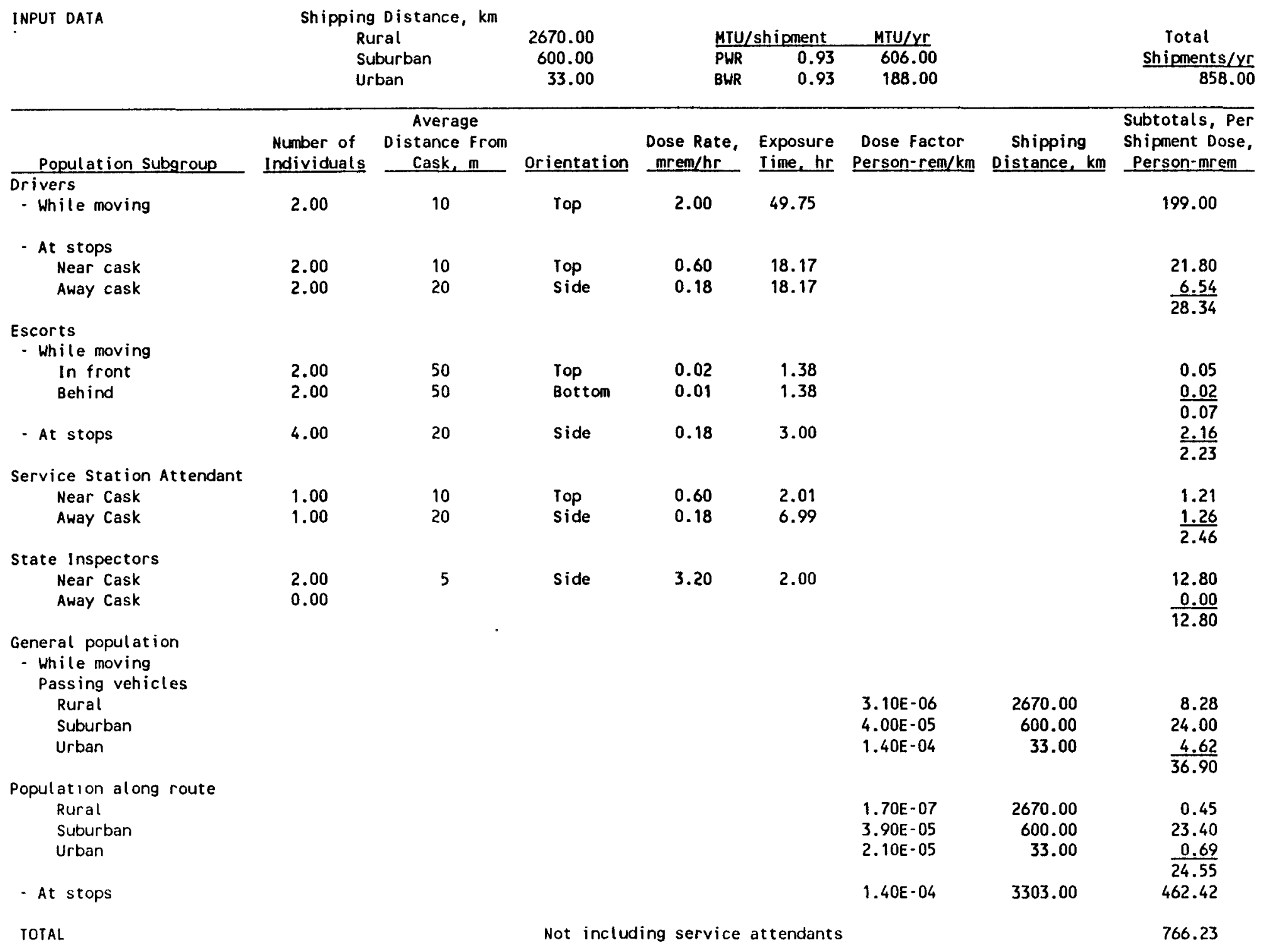


TABLE C.4. Summary of Estimated In-Transit Radiation Doses for Truck Shipments from Eastern Reactors to a Western MRS

\begin{tabular}{|c|c|c|c|c|}
\hline \multirow[b]{2}{*}{ Population Subgroup } & \multicolumn{3}{|c|}{ Collective Dose ${ }^{(a)}$} & \multirow{2}{*}{$\begin{array}{c}\text { Dose to } \\
\text { Maximally Exposed } \\
\text { Individual, mrem/yr }\end{array}$} \\
\hline & $\begin{array}{c}\text { Per-Shipment } \\
\text { Dose Person-mrem }\end{array}$ & $\begin{array}{l}\text { Person-mrem } \\
\text { per MTU }\end{array}$ & $\begin{array}{l}\text { Annual Dose, } \\
\text { Person-rem } / y r^{(c)}\end{array}$ & \\
\hline $\begin{array}{l}\text { Transport Workers } \\
\text { - Drivers } \\
\text { - Escorts } \\
\text { - Attendants } \\
\text { - Inspectors }\end{array}$ & $\begin{array}{r}227.34 \\
2.23 \\
2.46 \\
12.80\end{array}$ & $\begin{array}{r}246.04 \\
2.41 \\
2.67 \\
13.85\end{array}$ & $\begin{array}{r}195.06 \\
1.91 \\
2.11 \\
10.98\end{array}$ & $\begin{array}{r}2955.42 \\
121.72 \\
87.74 \\
688.00\end{array}$ \\
\hline $\begin{array}{l}\text { Total Transport } \\
\text { Workers }\end{array}$ & 242.37 & 262.30 & 207.95 & NA \\
\hline Public & $\underline{523.86}$ & $\underline{566.95}$ & $\underline{449.47}$ & $\underline{57.78 / 2.43^{(\mathrm{e})}}$ \\
\hline Grand Total & 766.23 & 829.26 & 657.42 & NA \\
\hline \multicolumn{5}{|c|}{$\begin{array}{l}\text { NA = Not Applicable } \\
\text { (a) Columns may not sum correctly because of round-off. } \\
\text { (b) Based on } 0.93 \text { MTU PWR fuel per shipment. } \\
\text { (c) Based on annual shipment quantities given in Table C.3. } \\
\text { (d) Not included in totals. } \\
\text { (e) First value is the maximum public exposure at stops. The } \\
\text { exposure to persons residing near the transport route. }\end{array}$} \\
\hline
\end{tabular}


TABLE C.5. In-Transit Dose Calculations for Truck Shipments From Western Reactors to the Yucca Mountain Repository

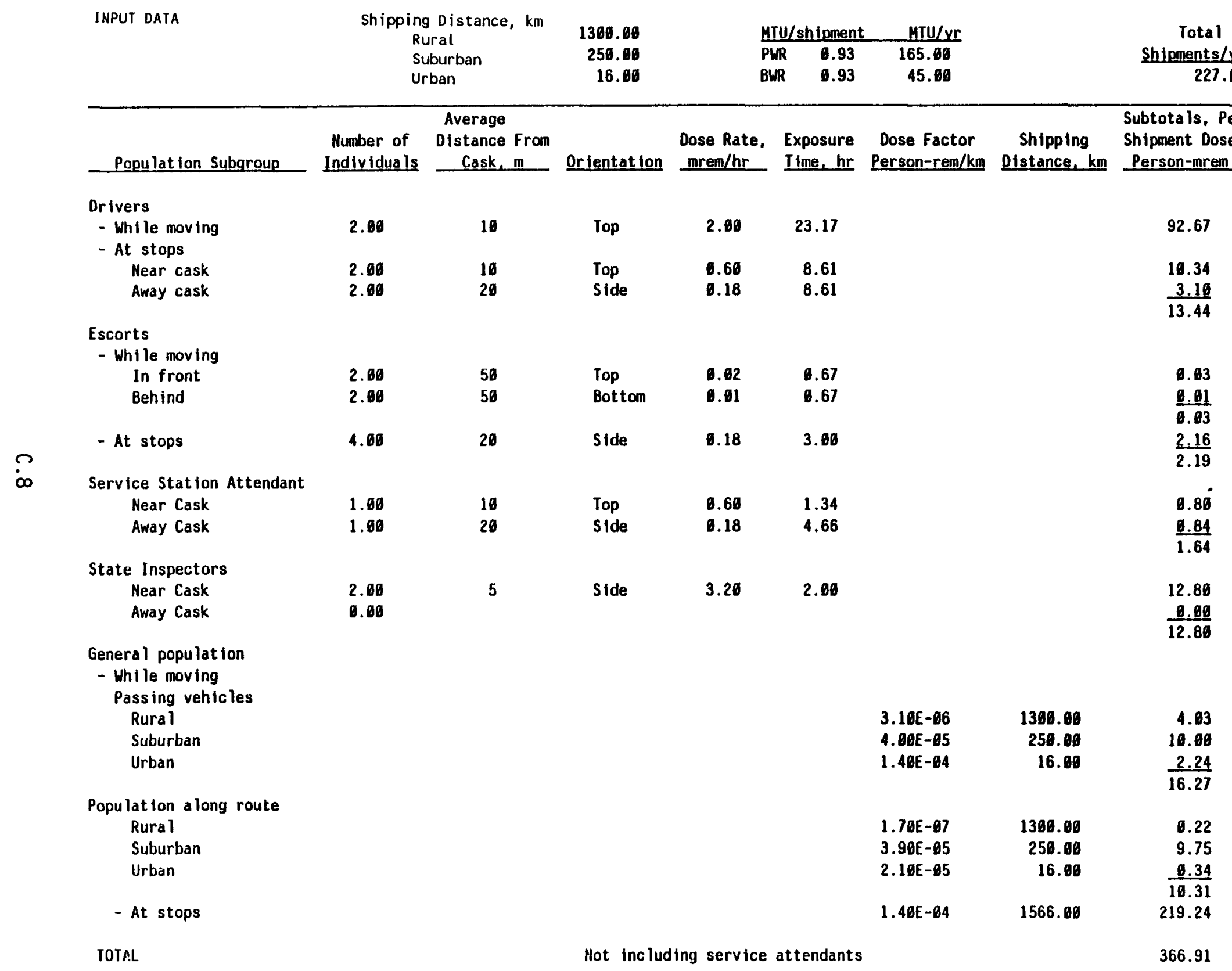


TABLE C.6. Summary of Estimated In-Transit Radiation Doses for Truck Shipments from Western Reactors to the Yucca Mountain Repository

\begin{tabular}{|c|c|c|c|c|}
\hline \multirow[b]{2}{*}{ Population Subgroup } & \multicolumn{3}{|c|}{ Collective Dose ${ }^{(a)}$} & \multirow{2}{*}{$\begin{array}{l}\text { Dose to } \\
\text { Maximally Exposed } \\
\text { Individual, mrem/yr }\end{array}$} \\
\hline & $\begin{array}{c}\text { Per-Shipment } \\
\text { Dose Person-mrem }\end{array}$ & $\begin{array}{l}\text { Person-prem } \\
\text { per MTU }\end{array}$ & $\begin{array}{l}\text { Annual Dose, } \\
\text { Person-rem/yr }(c)\end{array}$ & \\
\hline $\begin{array}{l}\text { Transport Workers } \\
\text { - Drivers } \\
\text { - Escorts } \\
\text { - Attendants (d) } \\
\text { - Inspectors }\end{array}$ & $\begin{array}{r}106.10 \\
2.19 \\
1.64 \\
12.80 \\
\end{array}$ & $\begin{array}{r}114.83 \\
2.37 \\
1.78 \\
13.85 \\
\end{array}$ & $\begin{array}{r}24.08 \\
0.50 \\
0.37 \\
2.91 \\
\end{array}$ & $\begin{array}{r}2546.47 \\
31.50 \\
22.96 \\
182.40 \\
\end{array}$ \\
\hline $\begin{array}{l}\text { Total Transport } \\
\text { Workers }\end{array}$ & 121.10 & 131.06 & 27.48 & NA \\
\hline Public & 245.82 & 266.04 & 55.79 & $\underline{57.12 / 0.64^{(\mathrm{e})}}$ \\
\hline Grand Total & 366.91 & 397.09 & 83.27 & NA \\
\hline
\end{tabular}

NA = Not Applicable

(a) Columns may not sum correctly because of round-off.

(b) Based on 0.93 MTU PWR fuel per shipment.

(c) Based on annual shipment quantities given in Table C.5.

(d) Not included in totals.

(e) First value is the maximum public exposure at stops. The second value is the maximum public exposure to persons residing near the transport route. 
TABLE C.7. In-Transit Dose Calculations for Truck Shipments from Western Reactors to a Western MRS

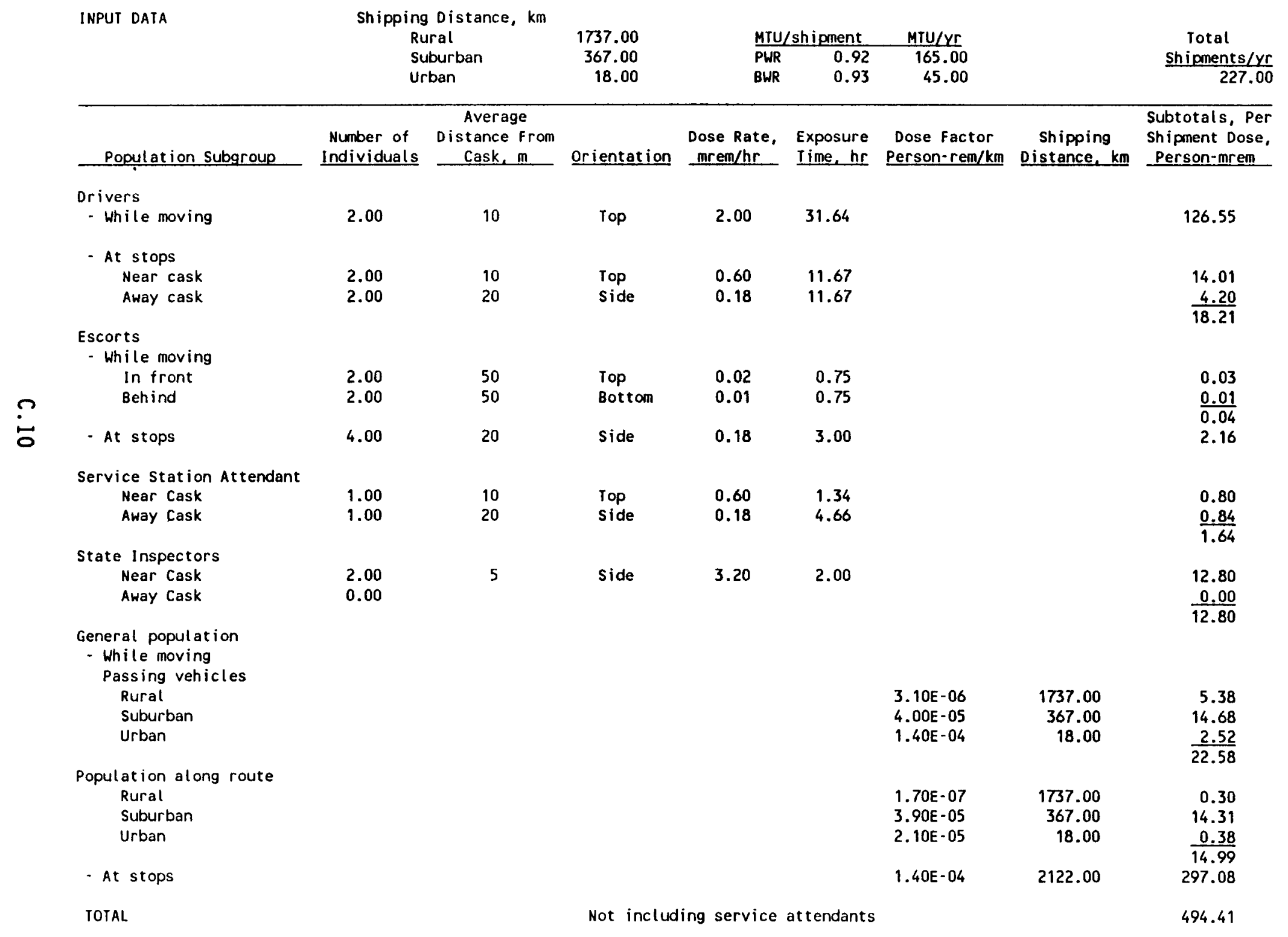


TABLE C.8. Summary of Estimated In-Transit Radiation Doses for Truck Shipments from Western Reactors to a Western MRS

\begin{tabular}{|c|c|c|c|c|}
\hline & & lective Dose & & \\
\hline Population Subgroup & $\begin{array}{c}\text { Per-Shipment } \\
\text { Dose Person-mrem }\end{array}$ & $\begin{array}{l}\text { Person-mfem } \\
\text { per MTU }(b)^{-}\end{array}$ & $\begin{array}{l}\text { Annual Dose, } \\
\text { Person-rem/yr (c) }\end{array}$ & $\begin{array}{l}\text { Maximally Exposed } \\
\text { Individual, } \mathrm{mrem} / \mathrm{yr}\end{array}$ \\
\hline
\end{tabular}

Transport Workers

- Drivers

- Escorts

- Attendants (d)

- Inspectors

144.76

2.20

1.64

12.80
156.66
2.38
1.78
13.85

32.85

0.50

0.37

2.91

2750.38

31.59

22.96

Total Transport

Workers

159.75

172.89

36.26

NA

$\stackrel{?}{\varpi}$

Public

334.65

$\underline{362.18}$

75.95

$57.12 / 0.64^{(e)}$

Grand Total

494.41

535.07

112.21

NA

$N A=$ Not Applicable

(a) Columns may not sum correctly because of round-off.

(b) Based on 0.93 MTU PWR fuel per shipment.

(c) Based on annual shipment quantities given in Table C.7.

(d) Not included in totals.

(e) First value is the maximum public exposure at stops. The second value is the maximum public exposure to persons residing near the transport route. 
IABLE C.9. In-Transit Dose Calculations for GFR Shipments from Eastern Reactors to an Eastern MRS

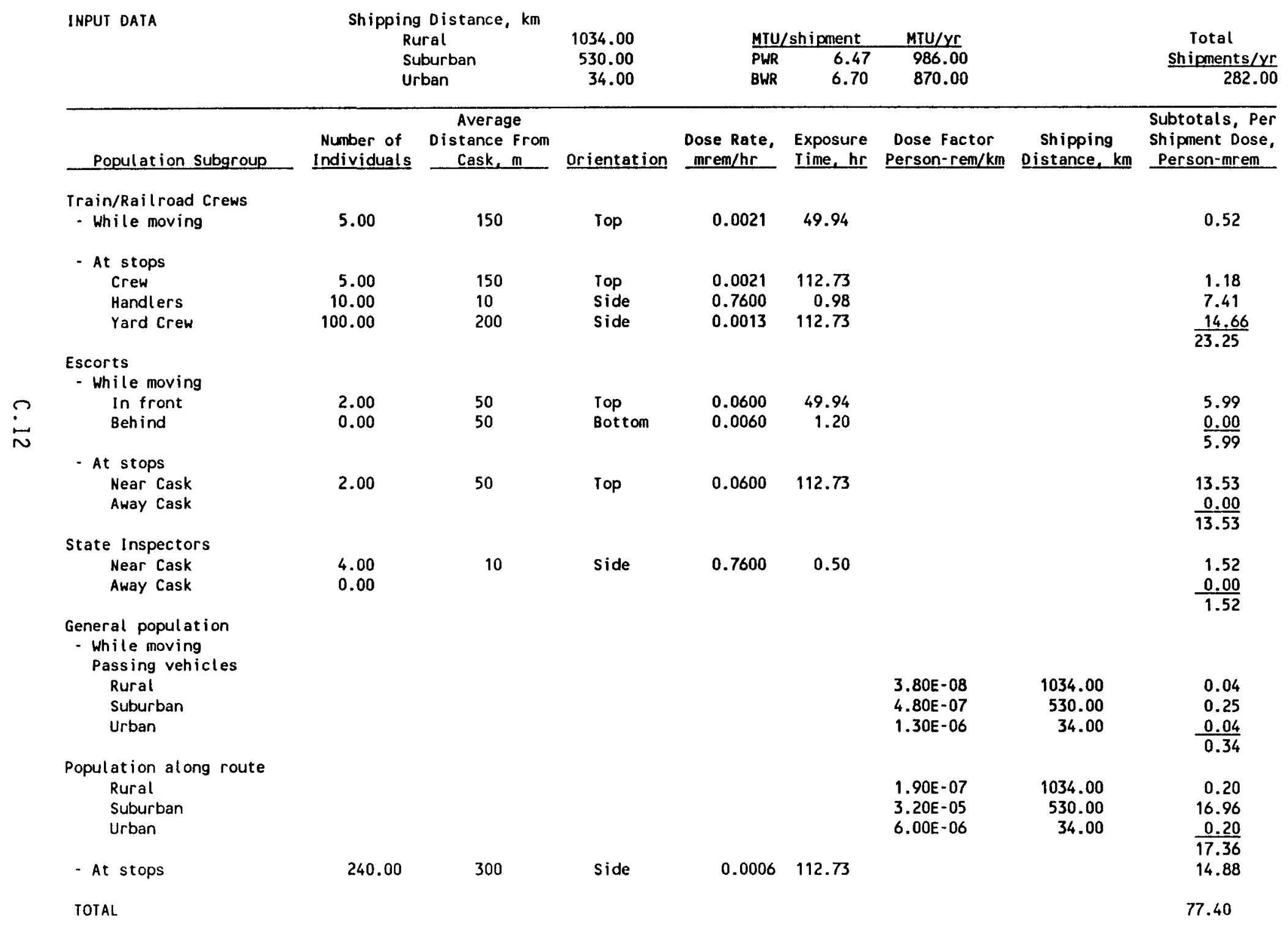


TABLE C.10. Summary of Estimated In-Transit Radiation Doses for GFR Shipments from Eastern Reactors to an Eastern MRS

\begin{tabular}{|c|c|c|c|c|}
\hline \multirow[b]{2}{*}{ Population Subgroup } & \multicolumn{3}{|c|}{ Collective Dose ${ }^{(a)}$} & \multirow{2}{*}{$\begin{array}{c}\text { Dose to } \\
\text { Maximally Exposed } \\
\text { Individual, mrem/yr }\end{array}$} \\
\hline & $\begin{array}{l}\text { Per-Shipment } \\
\text { Dose Person-mrem }\end{array}$ & $\begin{array}{l}\text { Person-mrem } \\
\text { per MTU }\end{array}$ & $\begin{array}{r}\text { Annual Dose, } \\
\text { Person-rem } / y^{(c)} \\
\end{array}$ & \\
\hline $\begin{array}{l}\text { Transport Workers } \\
\text { Train crew } \\
\text { Handlers } \\
\text { Yard crew } \\
\text { Escorts } \\
\text { Inspectors }\end{array}$ & $\begin{array}{r}1.71 \\
7.41 \\
14.66 \\
19.52 \\
1.52 \\
\end{array}$ & $\begin{array}{l}0.26 \\
1.15 \\
2.27 \\
3.02 \\
0.23 \\
\end{array}$ & $\begin{array}{l}0.48 \\
2.09 \\
4.14 \\
5.51 \\
0.43 \\
\end{array}$ & $\begin{array}{r}1.76 \\
10.72 \\
1.10 \\
101.52 \\
26.79 \\
\end{array}$ \\
\hline $\begin{array}{l}\text { Total Transport } \\
\text { Workers }\end{array}$ & \multicolumn{3}{|c|}{ Total Transport } & NA \\
\hline Public & 32.58 & 5.04 & 9.20 & $3.10 / 1.42^{(\mathrm{d})}$ \\
\hline Grand Total & 77.40 & 11.96 & 21.84 & NA \\
\hline \multicolumn{5}{|c|}{$\begin{array}{l}\text { NA = Not Applicable } \\
\text { (a) Columns may not sum correctly because of round-off. } \\
\text { (b) Based on } 0.93 \text { MTU PWR fuel per shipment. } \\
\text { (c) Based on annual shipment quantities given in Table } C .9 \text {. } \\
\text { (d) First value is the maximum public exposure at stops. The second value is the maximum public } \\
\text { exposure to persons residing near the transport route. }\end{array}$} \\
\hline
\end{tabular}


TABLE C.11. In-Transit Dose Calculations for GFR Shipments from Eastern Reactors to a Western MRS

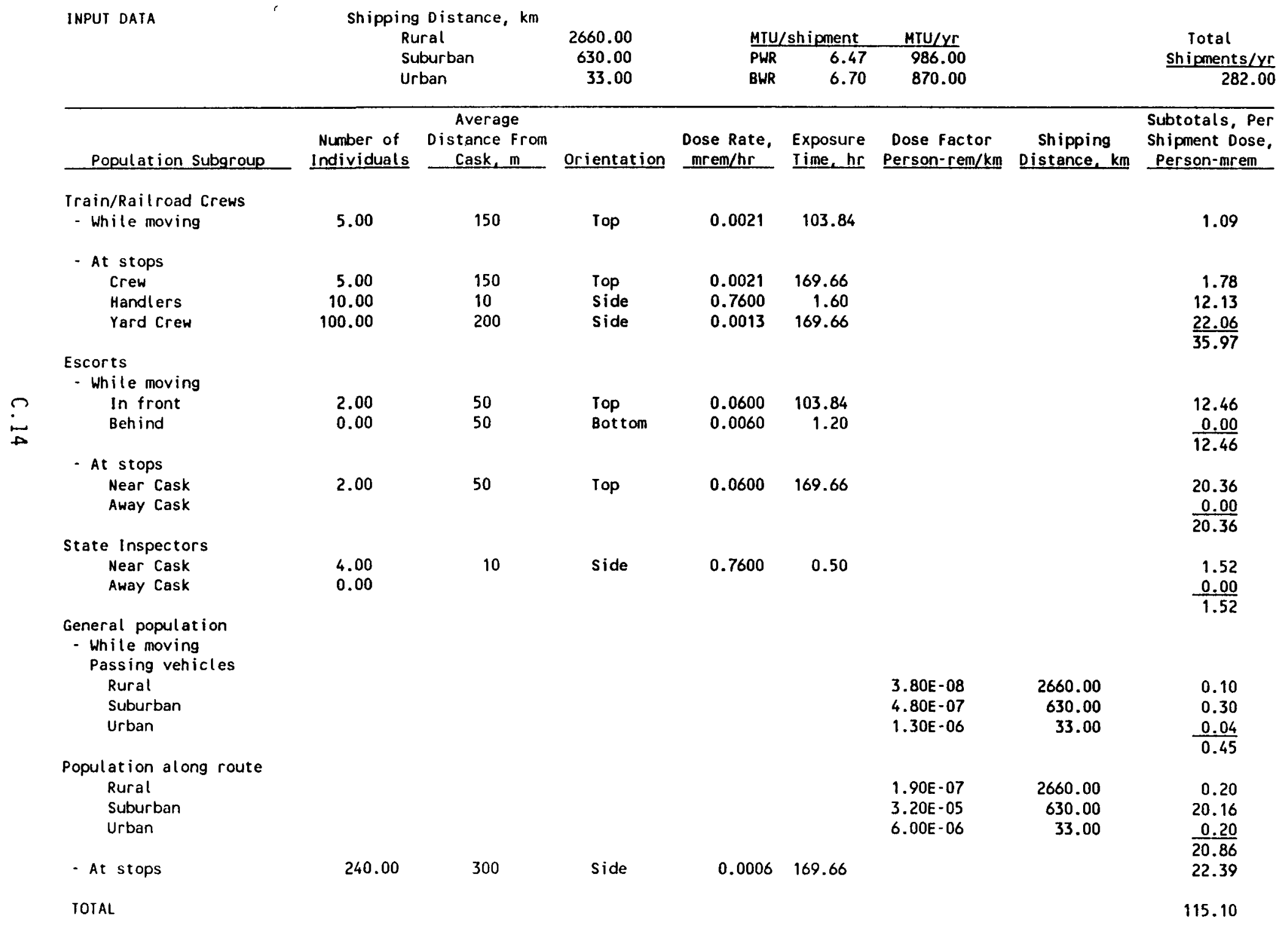


TABLE C.12. Summary of Estimated In-Transit Radiation Doses for GFR Shipments from Eastern Reactors to a Western MRS

\begin{tabular}{|c|c|c|c|c|}
\hline \multirow[b]{2}{*}{ Population Subgroup } & \multicolumn{3}{|c|}{ Collective Dose ${ }^{(a)}$} & \multirow{2}{*}{$\begin{array}{c}\text { Dose to } \\
\text { Maximally Exposed } \\
\text { Individual, } \mathrm{mrem} / \mathrm{yr}\end{array}$} \\
\hline & $\begin{array}{c}\text { Per-Shipment } \\
\text { Dose Person-mrem }\end{array}$ & $\begin{array}{l}\text { Person-mrem } \\
\text { per MTU }{ }^{(b)}\end{array}$ & $\begin{array}{r}\text { Annual Dose, } \\
\text { Person-rem/yr }{ }^{(\mathrm{c})}\end{array}$ & \\
\hline $\begin{array}{l}\text { Transport Workers } \\
\text { Train crew } \\
\text { Handlers } \\
\text { Yard crew } \\
\text { Escorts } \\
\text { Inspectors }\end{array}$ & $\begin{array}{r}2.87 \\
12.13 \\
22.06 \\
32.82 \\
1.52 \\
\end{array}$ & $\begin{array}{l}0.44 \\
1.88 \\
3.41 \\
5.07 \\
0.23 \\
\end{array}$ & $\begin{array}{l}0.81 \\
3.42 \\
6.23 \\
9.26 \\
0.43 \\
\end{array}$ & $\begin{array}{r}1.76 \\
10.72 \\
1.10 \\
101.52 \\
26.79 \\
\end{array}$ \\
\hline $\begin{array}{l}\text { Total Transport } \\
\text { Workers }\end{array}$ & 71.40 & 11.04 & 20.15 & NA \\
\hline Public & 43.70 & 6.75 & 12.34 & $3.10 / 1.42^{(d)}$ \\
\hline Grand Total & 115.10 & 17.79 & 32.49 & NA \\
\hline \multicolumn{5}{|c|}{$\begin{array}{l}\text { NA = Not Applicable } \\
\text { (a) Columns may not sum correctly because of round-off. } \\
\text { (b) Based on } 0.93 \text { MTU PWR fuel per shipment. } \\
\text { (c) Based on annual shipment quantities given in Table } C .11 \text {. } \\
\text { (d) First value is the maximum public exposure at stops. The second value is the maximum public } \\
\text { exposure to persons residing near the transport route. }\end{array}$} \\
\hline
\end{tabular}


TABLE C.13. In-Transit Dose Calculations for GFR Shipments from Western Reactors to the Yucca Mountain Repository

\begin{tabular}{|c|c|c|c|c|c|c|c|c|}
\hline INPUT DATA & $\begin{array}{r}\text { Shippins } \\
\text { RL } \\
\text { SL } \\
\text { Ur }\end{array}$ & $\begin{array}{l}\text { Distance, } \mathrm{km} \\
\text { ral } \\
\text { burban } \\
\text { ban }\end{array}$ & $\begin{array}{r}1510.00 \\
150.00 \\
34.00\end{array}$ & $\begin{array}{l}\text { MTU } \\
\text { PWR } \\
\text { BWR }\end{array}$ & $\begin{array}{r}\text { shipment } \\
6.47 \\
6.70\end{array}$ & $\begin{array}{r}\text { MTU/Yr } \\
140.00 \\
0.00\end{array}$ & & $\begin{array}{c}\begin{array}{c}\text { Total } \\
\text { Shipments/yr }\end{array} \\
22.00\end{array}$ \\
\hline Population Subgroup & $\begin{array}{l}\text { Number of } \\
\text { Individuals }\end{array}$ & $\begin{array}{c}\text { Average } \\
\text { Distance from } \\
\text { Cask, m } \\
\end{array}$ & Orientation & $\begin{array}{l}\text { Dose Rate, } \\
\text { mrem/hr }\end{array}$ & $\begin{array}{l}\text { Exposure } \\
\text { Iime, hr }\end{array}$ & $\begin{array}{l}\text { Dose Factor } \\
\text { Person-rem/km }\end{array}$ & $\begin{array}{c}\text { Shipping } \\
\text { Distance, } \mathrm{km}\end{array}$ & $\begin{array}{l}\text { Subtotals, Per } \\
\text { Shipment Dose, } \\
\text { Person-mrem }\end{array}$ \\
\hline $\begin{array}{l}\text { Train/Railroad Crews } \\
\text { - While moving }\end{array}$ & 5.00 & 150 & Top & 0.0021 & 52.94 & & & 0.56 \\
\hline $\begin{array}{l}\text { - At stops } \\
\text { Crew } \\
\text { Handlers } \\
\text { Yard Crew }\end{array}$ & $\begin{array}{r}5.00 \\
10.00 \\
100.00\end{array}$ & $\begin{array}{l}150 \\
10 \\
200\end{array}$ & $\begin{array}{l}\text { Top } \\
\text { Side } \\
\text { side }\end{array}$ & $\begin{array}{l}0.0021 \\
0.7600 \\
0.0013\end{array}$ & $\begin{array}{r}115.90 \\
1.01 \\
115.90\end{array}$ & & & $\begin{array}{l}1.22 \\
7.67 \\
\frac{15.07}{23.96}\end{array}$ \\
\hline $\begin{array}{l}\text { Escorts } \\
\text { - While moving }\end{array}$ & & & & & & & & \\
\hline $\begin{array}{l}\text { In front } \\
\text { Behind }\end{array}$ & $\begin{array}{l}2.00 \\
0.00\end{array}$ & $\begin{array}{l}50 \\
50\end{array}$ & $\begin{array}{l}\text { Top } \\
\text { Bottom }\end{array}$ & $\begin{array}{l}0.0600 \\
0.0060\end{array}$ & $\begin{array}{r}52.94 \\
1.20\end{array}$ & & & $\begin{array}{l}6.35 \\
0.00 \\
6.35\end{array}$ \\
\hline $\begin{array}{l}\text { - At stops } \\
\text { Near Cask } \\
\text { Away Cask }\end{array}$ & 2.00 & 50 & Top & 0.0600 & 115.90 & & & $\begin{array}{l}13.91 \\
0.00 \\
13.91\end{array}$ \\
\hline $\begin{array}{l}\text { State Inspectors } \\
\text { Near Cask } \\
\text { Away Cask }\end{array}$ & $\begin{array}{l}4.00 \\
0.00\end{array}$ & 10 & side & 0.7600 & 0.50 & & & $\begin{array}{l}1.52 \\
0.00 \\
1.52\end{array}$ \\
\hline $\begin{array}{l}\text { General population } \\
\text { - While moving } \\
\text { Passing vehicles } \\
\text { Rural } \\
\text { Suburban } \\
\text { Urban }\end{array}$ & & & & & & $\begin{array}{l}3.80 E-08 \\
4.80 E-07 \\
1.30 E-06\end{array}$ & $\begin{array}{r}1510.00 \\
150.00 \\
34.00\end{array}$ & $\begin{array}{l}0.06 \\
0.07 \\
0.04 \\
0.17\end{array}$ \\
\hline $\begin{array}{l}\text { Population along route } \\
\text { Rural } \\
\text { Suburban } \\
\text { Urban }\end{array}$ & & & & & & $\begin{array}{l}1.90 E-07 \\
3.20 E-05 \\
6.00 E-06\end{array}$ & $\begin{array}{r}1510.00 \\
150.00 \\
34.00\end{array}$ & $\begin{array}{l}0.29 \\
4.80 \\
0.20 \\
5.29\end{array}$ \\
\hline $\begin{array}{l}\text { - At stops } \\
\text { TOTAL }\end{array}$ & 240.00 & 300 & side & 0.0006 & 115.90 & & & $\begin{array}{l}15.30 \\
65.06\end{array}$ \\
\hline
\end{tabular}


TABLE C.14. Summary of Estimated In-Transit Radiation Doses for GFR Shipments from Western Reactors to the Yucca Mountain Repository

\begin{tabular}{|c|c|c|c|c|}
\hline \multirow[b]{2}{*}{ Population Subgroup } & \multicolumn{3}{|c|}{ Collective Dose ${ }^{(a)}$} & \multirow{2}{*}{$\begin{array}{c}\text { Dose to } \\
\text { Maximally Exposed } \\
\text { Individual, mrem/yr }\end{array}$} \\
\hline & $\begin{array}{c}\text { Per-Shipment } \\
\text { Dose Person-mrem }\end{array}$ & $\begin{array}{l}\text { Person-mrem } \\
\text { per MTU }{ }^{(b)}\end{array}$ & $\begin{array}{l}\text { Annual Dose, } \\
\text { Person-rem/yr } \\
\end{array}$ & \\
\hline $\begin{array}{l}\text { Transport Workers } \\
\text { Train crew } \\
\text { Handlers } \\
\text { Yard crew } \\
\text { Escorts } \\
\text { Inspectors }\end{array}$ & $\begin{array}{r}1.77 \\
7.67 \\
15.07 \\
20.26 \\
1.52 \\
\end{array}$ & $\begin{array}{l}0.27 \\
1.19 \\
2.33 \\
3.13 \\
0.23 \\
\end{array}$ & $\begin{array}{l}0.04 \\
0.17 \\
0.33 \\
0.44 \\
\underline{0.03} \\
\end{array}$ & $\begin{array}{l}0.14 \\
0.84 \\
0.09 \\
7.92 \\
2.09 \\
\end{array}$ \\
\hline \multicolumn{4}{|l|}{ Total Transport } & NA \\
\hline Public & 20.76 & 3.21 & 0.45 & $0.24 / 0.11^{(\mathrm{d})}$ \\
\hline Grand Total & 67.06 & 10.36 & 1.45 & NA \\
\hline \multicolumn{5}{|c|}{$\begin{array}{l}\text { NA = Not Applicable } \\
\text { (a) Columns may not sum correctly because of round-off. } \\
\text { (b) Based on } 6.47 \text { MTU PWR fuel per shipment. } \\
\text { (c) Based on annual shipment quantities given in Table C.13. } \\
\text { (d) First value is the maximum public exposure at stops. The second value is the maximum public } \\
\text { exposure to persons residing near the transport route. }\end{array}$} \\
\hline
\end{tabular}


TABLE C.15. In-Transit Dose Calculations for GFR Shipments from Western Reactors to a Western MRS

\begin{tabular}{|c|c|c|c|c|c|c|c|c|}
\hline INPUT DATA & $\begin{array}{r}\text { Shipping } \\
\text { RL } \\
\text { SL } \\
\text { Ur }\end{array}$ & $\begin{array}{l}\text { Distance, } \mathrm{km} \\
\text { ral } \\
\text { burban } \\
\text { ban }\end{array}$ & $\begin{array}{r}2092.00 \\
223.00 \\
35.00\end{array}$ & $\begin{array}{l}\text { MTU } \\
\text { PWR } \\
\text { BWR }\end{array}$ & $\begin{array}{r}\text { shipment } \\
6.47 \\
6.70\end{array}$ & $\begin{array}{r}\text { MIU/Yr } \\
140.00 \\
0.00\end{array}$ & & $\begin{array}{c}\begin{array}{c}\text { Total } \\
\text { Shipments } / y\end{array} \\
22.00\end{array}$ \\
\hline Population Subgroup & $\begin{array}{l}\text { Number of } \\
\text { Individuals }\end{array}$ & $\begin{array}{c}\text { Average } \\
\text { Distance from } \\
\text { Cask, m. } \\
\end{array}$ & Orientation & $\begin{array}{l}\text { Dose Rate, } \\
\text { mrem/hr }\end{array}$ & $\begin{array}{l}\text { Exposure } \\
\text { Iime, hr }\end{array}$ & $\begin{array}{l}\text { Dose Factor } \\
\text { Person-rem/km }\end{array}$ & $\begin{array}{c}\text { Shipping } \\
\text { Distance, } \mathrm{km}\end{array}$ & $\begin{array}{l}\text { Subtotals, Pe } \\
\text { Shipment Dose } \\
\text { Person-mrem } \\
\end{array}$ \\
\hline $\begin{array}{l}\text { Train/Railroad Crews } \\
\text { - While moving }\end{array}$ & 5.00 & 150 & Top & 0.0021 & 73.44 & & & 0.77 \\
\hline $\begin{array}{l}\text { - At stops } \\
\text { Crew } \\
\text { Handlers } \\
\text { Yard Crew }\end{array}$ & $\begin{array}{r}5.00 \\
10.00 \\
100.00\end{array}$ & $\begin{array}{l}150 \\
10 \\
200\end{array}$ & $\begin{array}{l}\text { Top } \\
\text { Side } \\
\text { Side }\end{array}$ & $\begin{array}{l}0.0021 \\
0.7600 \\
0.0013\end{array}$ & $\begin{array}{r}137.55 \\
1.25 \\
137.55\end{array}$ & & & $\begin{array}{r}1.44 \\
9.47 \\
17.88 \\
28.80\end{array}$ \\
\hline $\begin{array}{l}\text { Escorts } \\
\text { - While moving } \\
\text { In front } \\
\text { Behind }\end{array}$ & $\begin{array}{l}2.00 \\
0.00\end{array}$ & $\begin{array}{l}50 \\
50\end{array}$ & $\begin{array}{l}\text { Top } \\
\text { Bottom }\end{array}$ & $\begin{array}{l}0.0600 \\
0.0060\end{array}$ & $\begin{array}{r}73.44 \\
1.20\end{array}$ & & & $\begin{array}{l}8.81 \\
0.00 \\
8.81\end{array}$ \\
\hline $\begin{array}{l}\text { - At stops } \\
\text { Near Cask } \\
\text { Away Cask }\end{array}$ & 2.00 & 50 & Top & 0.0600 & 137.55 & & & $\begin{array}{r}16.51 \\
0.00 \\
16.51\end{array}$ \\
\hline $\begin{array}{c}\text { State Inspectors } \\
\text { Near Cask } \\
\text { Away Cask }\end{array}$ & $\begin{array}{l}4.00 \\
0.00\end{array}$ & 10 & side & 0.7600 & 0.50 & & & $\begin{array}{l}1.52 \\
0.00 \\
1.52\end{array}$ \\
\hline $\begin{array}{l}\text { General poputation } \\
\text { - While moving } \\
\text { Passing vehicles } \\
\text { Rural } \\
\text { Suburban } \\
\text { Urban }\end{array}$ & & & & & & $\begin{array}{l}3.80 E-08 \\
4.80 E-07 \\
1.30 E-06\end{array}$ & $\begin{array}{r}2092.00 \\
223.00 \\
35.00\end{array}$ & $\begin{array}{l}0.08 \\
0.11 \\
0.05 \\
0.23\end{array}$ \\
\hline $\begin{array}{l}\text { Population along route } \\
\text { Rural } \\
\text { Suburban } \\
\text { Urban }\end{array}$ & & & & & & $\begin{array}{l}1.90 E-07 \\
3.20 E-05 \\
6.00 E-06\end{array}$ & $\begin{array}{r}2092.00 \\
223.00 \\
35.00\end{array}$ & $\begin{array}{l}0.40 \\
7.14 \\
0.21 \\
7.74\end{array}$ \\
\hline - At stops & 240.00 & 300 & side & 0.0006 & 137.55 & & & 18.16 \\
\hline TOTAL & & & & & & & & 82.54 \\
\hline
\end{tabular}


TABLE C.16. Summary of Estimated In-Transit Radiation Doses for GFR Shipments from Western Reactors to a Western MRS

\begin{tabular}{|c|c|c|c|c|}
\hline \multirow{2}{*}{ Population Subgroup } & \multicolumn{3}{|c|}{ Collective Dose ${ }^{(a)}$} & \multirow{2}{*}{$\begin{array}{c}\text { Dose to } \\
\text { Maximally Exposed } \\
\text { Individual, mrem/yr }\end{array}$} \\
\hline & $\begin{array}{c}\text { Per-Shipment } \\
\text { Dose Person-mrem }\end{array}$ & $\begin{array}{l}\text { Person-mrem } \\
\text { per MTU }\end{array}$ & $\begin{array}{r}\text { Annual Dose } \\
\text { Person-rem/yr }\end{array}$ & \\
\hline $\begin{array}{l}\text { Transport Workers } \\
\text { Train crew } \\
\text { Handlers } \\
\text { Yard crew } \\
\text { Escorts } \\
\text { Inspectors }\end{array}$ & $\begin{array}{r}2.22 \\
9.47 \\
17.88 \\
25.32 \\
1.52 \\
\end{array}$ & $\begin{array}{l}0.34 \\
1.46 \\
2.76 \\
3.91 \\
0.23 \\
\end{array}$ & $\begin{array}{l}0.05 \\
0.20 \\
0.39 \\
0.55 \\
0.03 \\
\end{array}$ & $\begin{array}{l}0.14 \\
0.84 \\
0.09 \\
7.92 \\
2.09 \\
\end{array}$ \\
\hline $\begin{array}{l}\text { Total Transport } \\
\text { Workers }\end{array}$ & 56.40 & 8.72 & 1.22 & NA \\
\hline Public & 26.13 & 4.04 & 0.57 & $0.24 / 0.11^{(d)}$ \\
\hline Grand Total & 82.54 & 12.76 & 1.79 & NA \\
\hline \multicolumn{5}{|c|}{$\begin{array}{l}\text { NA = Not Applicable } \\
\text { (a) Columns may not sum correctly because of round-off. } \\
\text { (b) Based on } 6.47 \text { MTU PWR fuel per shipment. } \\
\text { (c) Based on annual shipment quantities given in Table } C .13 \text {. } \\
\text { (d) First value is the maximum public exposure at stops. The second value is the maximum public } \\
\text { exposure to persons residing near the transport route. }\end{array}$} \\
\hline
\end{tabular}


IABLE C.17. In-Transit Dose Calculations for Dedicated Train Shipments of Consolidated Fuel with Hardware in Canisters (Eastern MRS)

\begin{tabular}{|c|c|c|c|c|c|c|c|c|}
\hline \multirow[t]{2}{*}{ INPUT DATA } & $\begin{array}{r}\text { Shipping } \\
\text { RU }\end{array}$ & $\begin{array}{l}\text { Distance, } \mathrm{km} \\
\text { ral }\end{array}$ & 2023.00 & \multicolumn{2}{|c|}{ MTU/shipment } & \multirow{2}{*}{\multicolumn{2}{|c|}{ 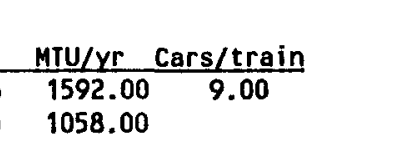 }} & \multirow{2}{*}{$\begin{array}{c}\begin{array}{c}\text { Total } \\
\text { Shipments/yr }\end{array} \\
20.00\end{array}$} \\
\hline & & $\begin{array}{l}\text { burban } \\
\text { ban }\end{array}$ & $\begin{array}{r}282.00 \\
47.00\end{array}$ & $\begin{array}{l}\text { PWR } \\
\text { BWR }\end{array}$ & $\begin{array}{l}129.36 \\
130.20\end{array}$ & & & \\
\hline Population Subgroup & $\begin{array}{c}\text { Number of } \\
\text { Individuals }\end{array}$ & $\begin{array}{c}\text { Average } \\
\text { Distance From } \\
\text { Cask, m } \\
\end{array}$ & Orientation & $\begin{array}{l}\text { Dose Rate, } \\
\text { mrem/hr }\end{array}$ & $\begin{array}{l}\text { Exposure } \\
\text { Iime, hr }\end{array}$ & $\begin{array}{l}\text { Dose Factor } \\
\text { Person-rem/km }\end{array}$ & $\begin{array}{c}\text { Shipping } \\
\text { Distance, km }\end{array}$ & $\begin{array}{l}\text { Subtotals, Per } \\
\text { Shipment Dose, } \\
\text { Person-mrem }\end{array}$ \\
\hline
\end{tabular}

$\begin{array}{lr}\text { Train/Railroad Crews } & \\ \text { - While moving } & \\ & \\ \text { - At stops } & \\ \text { Crew } & 5.00 \\ \text { Handlers } & 3.00 \\ \text { Yard Crew } & 100.00\end{array}$

$\begin{aligned} 30 & \text { Top } \\ 30 & \text { Top } \\ 10 & \text { Side } \\ 100 & \text { Side }\end{aligned}$

$\begin{array}{lccl}\text { Top } & 0.07 & 73.50 & \\ \text { Top } & 0.07 & 11.41 & \\ \text { Side } & 0.76 & 4.67 & \\ \text { Side } & 0.01 & \begin{array}{l}6.23 \\ \text { stops/trip }\end{array} & \begin{array}{l}1.60 \mathrm{l}-06 \\ \text { rem/person } \\ \text { per stop }\end{array}\end{array}$

25.73

3.99

$\begin{array}{r}8.98 \\ \hline\end{array}$

49.35

$\begin{array}{cc}\text { n } & \text { Escorts } \\ \text { in } & \text { - While moving } \\ \text { O In frant } & \text { - At stops }\end{array}$

Near Cask

2.00

30

Bottom

0.19

73.50

27.93

2.00

30

Bottom

0.19

11.41

$\frac{4.34}{32.27}$

State Inspectors Near Cask

2.00

10

side

0.76

3.00

General population

- While moving

Passing vehicles

Rural

Suburban

Urban

Population along route

Rural

Suburban

Urban

At stops

240.00

300

side

0.00

11.41

TOTAL

4.56
0.00

$\frac{0.00}{4.56}$

Subtotal: Workers 86.17

$\begin{array}{lrr}3.80 E-08 & 2023.00 & 0.69 \\ 4.80 E-07 & 282.00 & 1.22 \\ 1.30 E-06 & 47.00 & \frac{0.55}{2.46} \\ & & \\ 1.90 E-07 & 2023.00 & 3.46 \\ 3.20 E-05 & 282.00 & 81.22 \\ 6.00 E-06 & 47.00 & \frac{2.54}{87.21} \\ & & 4.22 \\ 0.37 & \text { person-mrem/hr } & \\ & \text { Subtotal: Public } & 93.89\end{array}$

180.06 
IABLE C.18. Summary of Estimated In-Transit Radiation Doses for Dedicated Train Shipments of Consolidated Fuel; Hardware in Canisters (Eastern MRS)

\begin{tabular}{|c|c|c|c|c|}
\hline \multirow{2}{*}{ Population Subgroup } & \multicolumn{3}{|c|}{ Collective Dose ${ }^{(a)}$} & \multirow{2}{*}{$\begin{array}{c}\text { Dose to } \\
\text { Maximally Exposec } \\
\text { Individual, mrem/yr }\end{array}$} \\
\hline & $\begin{array}{c}\text { Per-Shipment } \\
\text { Dose Person-mrem }\end{array}$ & $\begin{array}{l}\text { Person-mrem } \\
\text { per MTU }\end{array}$ & $\begin{array}{r}\text { Annual Dose, } \\
\text { Person-rem/yr }\end{array}$ & \\
\hline $\begin{array}{l}\text { Transport Workers } \\
\text { Train crew } \\
\text { Handlers } \\
\text { Yard crew } \\
\text { Escorts } \\
\text { Inspectors }\end{array}$ & $\begin{array}{r}29.72 \\
10.66 \\
8.98 \\
32.27 \\
4.56 \\
\end{array}$ & $\begin{array}{l}0.23 \\
0.08 \\
0.07 \\
0.25 \\
0.04 \\
\end{array}$ & $\begin{array}{l}0.61 \\
0.22 \\
0.18 \\
0.66 \\
0.09 \\
\end{array}$ & $\begin{array}{r}16.80 \\
2.85 \\
0.28 \\
45.60 \\
11.40 \\
\end{array}$ \\
\hline $\begin{array}{l}\text { Total Transport } \\
\text { Workers }\end{array}$ & 86.17 & 0.67 & 1.76 & NA \\
\hline Public & 93.89 & 0.73 & 1.92 & $0.20 / 0.90^{(\mathrm{d})}$ \\
\hline Grand Total & 180.06 & 1.39 & 3.68 & NA \\
\hline \multicolumn{5}{|c|}{$\begin{array}{l}\text { NA = Not Applicable } \\
\text { (a) Columns may not sum correctly because of round-off. } \\
\text { (b) Based on } 6.47 \text { MTU PWR fuel per shipment. } \\
\text { (c) Based on annual shipment quantities given in Table C.17. } \\
\text { (d) First value is the maximum public exposure at stops. The second value is the maximum public } \\
\text { exposure to persons residing near the transport route. }\end{array}$} \\
\hline
\end{tabular}


TABLE C.19. In-Transit Dose Calculations for Dedicated Train Shipments of Consolidated Fuel with Hardware in Drums (Eastern MRS)

INPUT DATA

Shipping Distance, km

$\begin{array}{lr}\text { Rural } & 2023.00 \\ \text { Suburban } & 282.00 \\ \text { Urban } & 47.00\end{array}$

\begin{tabular}{|c|c|c|c|c|}
\hline MTU & ipment & MTU/Yr & Cars/train & Total \\
\hline PWR & 129.36 & 1592.00 & 10.00 & Shipments/yr \\
\hline BWR & 130.20 & 1058.00 & & 20.00 \\
\hline
\end{tabular}

Population Subgroup

Average

Number of Average

47.00

Individuals

orientation

Dose Rate,

Exposure

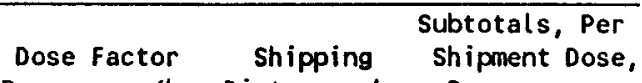

Train/Railroad Crews

- While moving

5.00

30

Top

0.07

73.50

25.73

- At stops

Crew

Handlers

Yard Crew

5.00
10.00

100.00

30

Top

side

$\begin{array}{lr}0.07 & 11.41 \\ 0.76 & 5.19 \\ 0.01 & 6.23 \\ & \text { stops/trip }\end{array}$

$1.60 E-06$
rem/person

3.99
11.84

100

side

per stop

Escorts

While moving

In front

N

At stops

Near Cask

2.00

Bottom

0.19

73.50

51.53

2.00

30

Bottom

$0.19 \quad 11.41$

State Inspectors

Near Cask

2.00

10

side

0.76

3.33

General population

- While moving

Passing vehicles

Rural

Suburban

Urban

Population along route

Rural

Suburban

Urban

240.00

300

Side

0.00

11.41

0.37 person-mrem/hr

27.93

$\frac{4.34}{32.27}$

5.06

$\frac{5.06}{88.86}$

$\begin{array}{lrr}3.80 E-08 & 2023.00 & 0.77 \\ 4.80 E-07 & 282.00 & 1.35 \\ 1.30 E-06 & 47.00 & 0.61 \\ & & 2.73 \\ 1.90 E-07 & 2023.00 & 3.84 \\ 3.20 E-05 & 282.00 & 90.24 \\ 6.00 E-06 & 47.00 & 2.82 \\ & & 96.90 \\ .37 \text { person-mrem/hr } & 4.22\end{array}$

Subtotal: Public 103.86 
TABLE C.20. Summary of Estimated In-Transit Radiation Doses for Dedicated Train Shipments of Consolidated Fuel; Hardware in Drums (Eastern MRS)

\begin{tabular}{|c|c|c|c|c|}
\hline \multirow{2}{*}{ Population Subgroup } & \multicolumn{3}{|c|}{ Collective Dose ${ }^{(a)}$} & \multirow{2}{*}{$\begin{array}{c}\text { Dose to } \\
\text { Maximally Exposec } \\
\text { Individual, mrem/yr }\end{array}$} \\
\hline & $\begin{array}{c}\text { Per-Shipment } \\
\text { Dose Person-mrem }\end{array}$ & $\begin{array}{l}\text { Person-mrem } \\
\text { per MTU }{ }^{(b)}\end{array}$ & $\begin{array}{l}\text { Annual Dose, } \\
\text { Person-rem } / y r^{(c)}\end{array}$ & \\
\hline $\begin{array}{l}\text { Transport Workers } \\
\text { Train crew } \\
\text { Handlers } \\
\text { Yard crew } \\
\text { Escorts } \\
\text { Inspectors }\end{array}$ & $\begin{array}{r}29.72 \\
11.84 \\
9.97 \\
32.27 \\
5.06 \\
\end{array}$ & $\begin{array}{l}0.23 \\
0.09 \\
0.08 \\
0.25 \\
0.04 \\
\end{array}$ & $\begin{array}{l}0.61 \\
0.24 \\
0.20 \\
0.66 \\
0.10 \\
\end{array}$ & $\begin{array}{r}16.80 \\
2.85 \\
0.28 \\
45.60 \\
11.40 \\
\end{array}$ \\
\hline $\begin{array}{l}\text { Total Transport } \\
\text { Workers }\end{array}$ & 88.86 & 0.69 & 1.82 & NA \\
\hline Public & $\underline{103.86}$ & 0.80 & 2.12 & $0.20 / 0.90^{(d)}$ \\
\hline Grand Total & 192.72 & 1.49 & 3.94 & NA \\
\hline \multicolumn{5}{|c|}{$\begin{array}{l}\text { NA = Not Applicable } \\
\text { (a) Columns may not sum correctly because of round-off. } \\
\text { (b) Based on } 6.47 \text { MTU PWR fuel per shipment. } \\
\text { (c) Based on annual shipment quantities given in Table } C .19 \text {. } \\
\text { (d) First value is the maximum public exposure at stops. The second value is the maximum public } \\
\text { exposure to persons residing near the transport route. }\end{array}$} \\
\hline
\end{tabular}


TABLE C.21. In-Transit Dose Calculations for Dedicated Train Shipments of Unconsolidated Fuel (Eastern MRS)

\begin{tabular}{|c|c|c|c|c|c|c|c|c|}
\hline INPUT DATA & $\begin{array}{r}\text { Shipping } \\
\text { Ru } \\
\text { SU } \\
\text { Ur }\end{array}$ & $\begin{array}{l}\text { Distance, } \mathrm{km} \\
\text { rat } \\
\text { burban } \\
\text { ban }\end{array}$ & $\begin{array}{r}2023.00 \\
282.00 \\
47.00\end{array}$ & $\begin{array}{l}\text { MTU } \\
\text { PWR } \\
\text { BWR }\end{array}$ & $\begin{array}{l}\text { U/shipment } \\
R\end{array}$ & $\begin{array}{l}\text { MTU/yr Cars } \\
1592.00 \\
1058.00\end{array}$ & $\frac{s / \text { train }}{6.00}$ & $\begin{array}{l}\begin{array}{c}\text { Total } \\
\text { hipments } / y r\end{array} \\
43.00\end{array}$ \\
\hline Population Subgroup & $\begin{array}{l}\text { Number of } \\
\text { Individuals }\end{array}$ & $\begin{array}{c}\text { Average } \\
\text { Distance From } \\
\text { Cask, m } \\
\end{array}$ & Orientation & $\begin{array}{c}\text { Dose Rate, } \\
\text { mrem/hr }\end{array}$ & $\begin{array}{r}\text { Exposure } \\
\text { Iime, hr } \\
\end{array}$ & $\begin{array}{l}\text { Dose Factor } \\
\text { Person-rem } / \mathrm{km}\end{array}$ & $\begin{array}{cc} & \text { Sul } \\
\text { Shipping } & \mathrm{Sh} \\
\text { Distance, } \mathrm{km} & \mathrm{P} \\
\end{array}$ & $\begin{array}{l}\text { Subtotals, P } \\
\text { Shipment Dos } \\
\text { Person-mrem }\end{array}$ \\
\hline $\begin{array}{l}\text { Train/Railroad Crews } \\
\text { - While moving }\end{array}$ & 5.00 & 30 & Top & 0.07 & 73.50 & & & 25.73 \\
\hline At stops & & & & & & & & \\
\hline Crew & 5.00 & 30 & Top & 0.07 & 11.41 & & & 3.99 \\
\hline Handlers & 3.00 & 10 & side & 0.76 & 3.12 & & & 7.10 \\
\hline Yard Crew & 100.00 & 100 & side & 0.01 st & $\begin{array}{c}6.23 \\
\text { tops/trip }\end{array}$ & $\begin{array}{l}1.60 E-06 \\
\text { rem/person } \\
\text { per stoo }\end{array}$ & & $\frac{5.98}{42.81}$ \\
\hline Escorts & & & & & & & & \\
\hline $\begin{array}{l}\text { - While moving } \\
\text { in front }\end{array}$ & 2.00 & 30 & Bottom & 0.19 & 73.50 & & & 27.93 \\
\hline $\begin{array}{l}\text { - At stops } \\
\text { Near Cask }\end{array}$ & 2.00 & 30 & Bottom & 0.19 & 11.41 & & & $\frac{4.34}{32.27}$ \\
\hline State Inspectors & & & & & & & & \\
\hline $\begin{array}{l}\text { Near Cask } \\
\text { Away Cask }\end{array}$ & $\begin{array}{l}2.00 \\
0.00\end{array}$ & 10 & Side & 0.76 & 2.00 & & & $\begin{array}{l}3.04 \\
0.00 \\
3.04\end{array}$ \\
\hline & & & & & & Subt & otal: Workers & $\frac{3.07}{78.11}$ \\
\hline $\begin{array}{l}\text { General population } \\
\text { - While moving } \\
\text { Passing vehicles }\end{array}$ & & & & & & & & \\
\hline Rural & & & & & & $3.80 E-08$ & 2023.00 & 0.46 \\
\hline $\begin{array}{l}\text { Suburban } \\
\text { Urban }\end{array}$ & & & & & & $\begin{array}{l}4.80 E-07 \\
1.30 E-06\end{array}$ & $\begin{array}{r}282.00 \\
47.00\end{array}$ & $\begin{array}{l}1.81 \\
0.37 \\
1.64\end{array}$ \\
\hline Population along route & & & & & & & & \\
\hline $\begin{array}{l}\text { Rural } \\
\text { Suburban } \\
\text { Urban }\end{array}$ & & & & & & $\begin{array}{l}1.90 E-07 \\
3.20 E-05 \\
6.00 E-06\end{array}$ & $\begin{array}{r}2023.00 \\
282.00 \\
47.00\end{array}$ & $\begin{array}{r}2.31 \\
54.14 \\
1.69 \\
58.1\end{array}$ \\
\hline - At stops & 240.00 & 300 & side & 0.00 & 11.41 & 0.37 & person-mrem/hr & $\begin{array}{l}38.14 \\
4.22\end{array}$ \\
\hline & & & & & & & Subtotal: Public & 64.00 \\
\hline TOTAL & & & & & & & & 142.11 \\
\hline
\end{tabular}


IABLE C.22. Summary of Estimated In-Transit Radiation Doses for Dedicated Train Shipments of Unconsolidated Fuel (Eastern MRS)

\begin{tabular}{|c|c|c|c|c|}
\hline & \multicolumn{3}{|c|}{ Collective Dose ${ }^{(a)}$} & \multirow{2}{*}{$\begin{array}{c}\text { Dose to } \\
\text { Maximally Exposed } \\
\text { Individual, mrem/yr }\end{array}$} \\
\hline Population Subgroup & $\begin{array}{c}\text { Per-Shipment } \\
\text { Dose Person-mrem }\end{array}$ & $\begin{array}{l}\text { Person-mrem } \\
\text { per MTU }{ }^{(b)}\end{array}$ & $\begin{array}{r}\text { Annual Dose, } \\
\text { Person-rem } / y^{(c)}\end{array}$ & \\
\hline $\begin{array}{l}\text { Transport Workers } \\
\text { Train crew } \\
\text { Handlers } \\
\text { Yard crew } \\
\text { Escorts } \\
\text { Inspectors }\end{array}$ & $\begin{array}{r}29.72 \\
7.10 \\
5.98 \\
32.27 \\
3.04 \\
\end{array}$ & $\begin{array}{l}0.46 \\
0.11 \\
0.09 \\
0.50 \\
0.05 \\
\end{array}$ & $\begin{array}{l}1.29 \\
0.31 \\
0.26 \\
1.40 \\
0.13 \\
\end{array}$ & $\begin{array}{r}36.12 \\
6.27 \\
0.60 \\
98.04 \\
24.51 \\
\end{array}$ \\
\hline $\begin{array}{l}\text { Total Transport } \\
\text { Workers }\end{array}$ & 78.11 & 1.21 & 3.38 & NA \\
\hline Public & 64.00 & 0.99 & 2.77 & $0.43 / 1.94^{(\mathrm{d})}$ \\
\hline Grand Total & 142.11 & 10.36 & 1.45 & NA \\
\hline \multicolumn{5}{|c|}{$\begin{array}{l}\text { NA = Not Applicable } \\
\text { (a) Columns may not sum correctly because of round-off. } \\
\text { (b) Based on } 6.47 \text { MTU PWR fuel per shipment. } \\
\text { (c) Based on annual shipment quantities given in Table } C .21 \text {. } \\
\text { (d) First value is the maximum public exposure at stops. The second value is the maximum public } \\
\text { exposure to persons residing near the transport route. }\end{array}$} \\
\hline
\end{tabular}


TABLE C.23. In-Transit Dose Calculations for Dedicated Train Shipments of Consolidated Fuel with Hardware in Canisters (Western MRS)

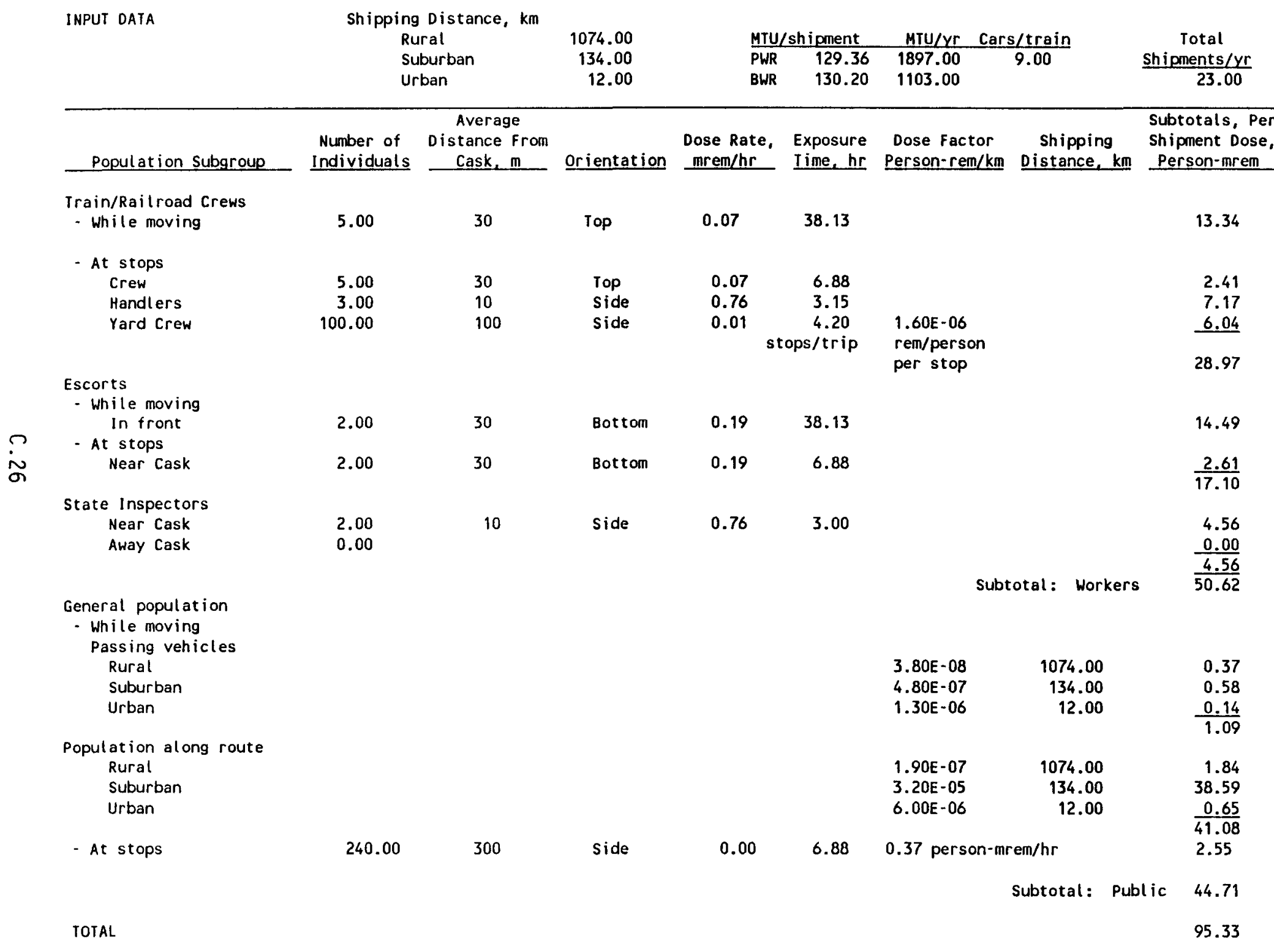


IABLE C.24. Summary of Estimated In-Transit Radiation Doses for Dedicated Train Shipments of Consolidated Fuel; Hardware in Canisters (Western MRS)

\begin{tabular}{|c|c|c|c|c|}
\hline & \multicolumn{3}{|c|}{ Collective Dose ${ }^{(a)}$} & \multirow{2}{*}{$\begin{array}{c}\text { Dose to } \\
\text { Maximally Exposed } \\
\text { Individual, mrem/yr }\end{array}$} \\
\hline Population Subgroup & $\begin{array}{c}\text { Per-Shipment } \\
\text { Dose Person-mrem }\end{array}$ & $\begin{array}{l}\text { Person-mrem } \\
\text { per MTU }\end{array}$ & $\begin{array}{r}\text { Annual Dose, } \\
\text { Person-rem/yr } \\
\end{array}$ & \\
\hline $\begin{array}{l}\text { Transport Workers } \\
\text { Train crew } \\
\text { Handlers } \\
\text { Yard crew } \\
\text { Escorts } \\
\text { Inspectors }\end{array}$ & $\begin{array}{r}15.75 \\
7.17 \\
6.04 \\
17.10 \\
4.56 \\
\end{array}$ & $\begin{array}{l}0.12 \\
0.06 \\
0.05 \\
0.13 \\
0.04 \\
\end{array}$ & $\begin{array}{l}0.36 \\
0.17 \\
0.14 \\
0.40 \\
0.11 \\
\end{array}$ & $\begin{array}{r}19.32 \\
3.42 \\
0.32 \\
52.44 \\
13.11 \\
\end{array}$ \\
\hline $\begin{array}{l}\text { Total Transport } \\
\text { Workers }\end{array}$ & 50.62 & 0.39 & 1.17 & NA \\
\hline Public & 44.71 & 0.35 & 1.03 & $0.23 / 1.04^{(d)}$ \\
\hline Grand Total & 95.33 & 0.74 & 2.21 & NA \\
\hline \multicolumn{5}{|c|}{$\begin{array}{l}\text { NA = Not Applicable } \\
\text { (a) Columns may not sum correctly because of round-off. } \\
\text { (b) Based on } 129.36 \text { MTU PWR fuel per shipment. } \\
\text { (c) Based on annual shipment quantities given in Table C. } 23 \text {. } \\
\text { (d) First value is the maximum public exposure at stops. The second value is the maximum public } \\
\text { exposure to persons residing near the transport route. }\end{array}$} \\
\hline
\end{tabular}


TABLE C.25. In-Transit Dose Calculations for Dedicated Train Shipments of Consolidated Fuel with Hardware in Drums (Western MRS)

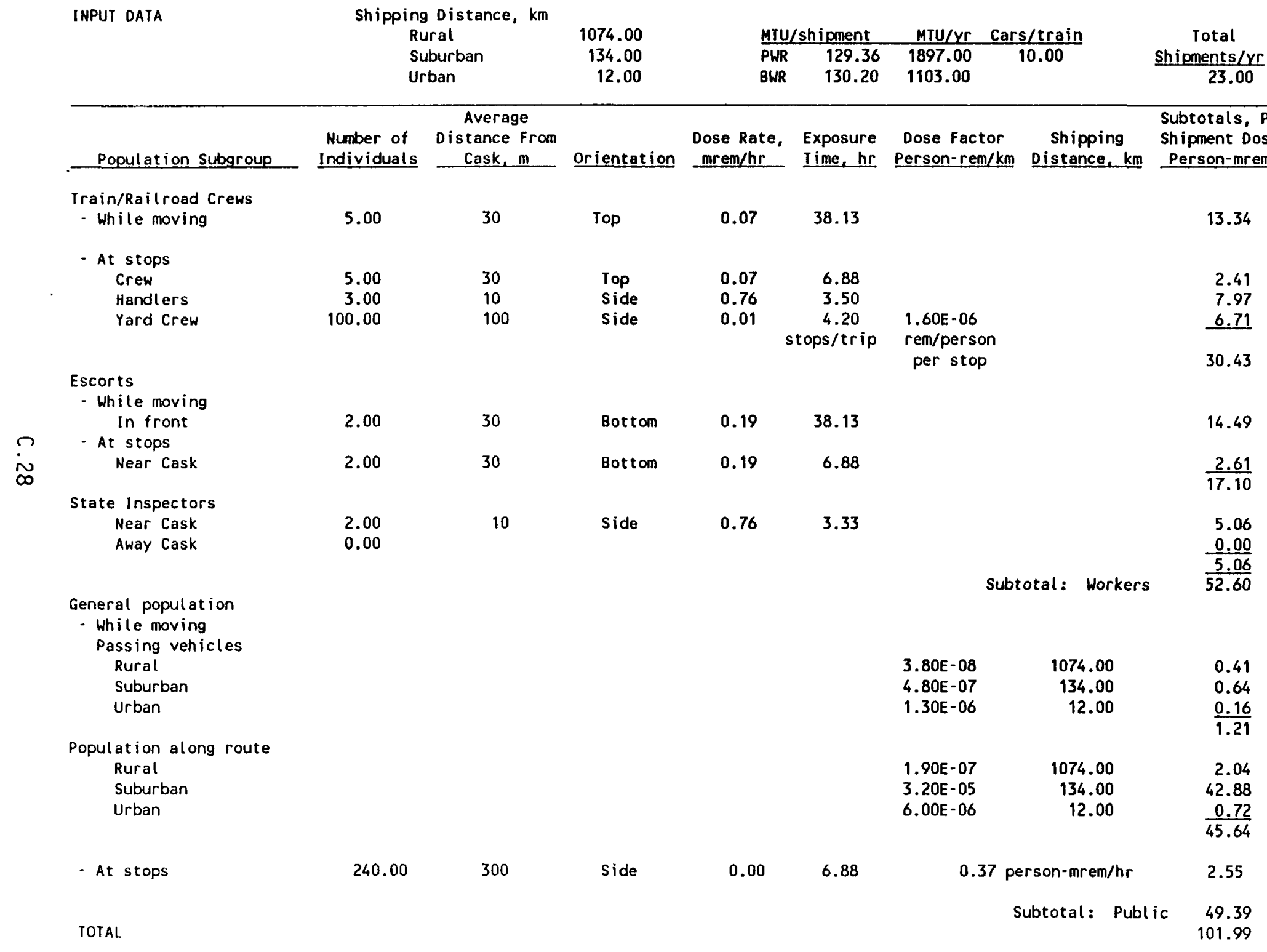


TABLE C.26. Summary of Estimated In-Transit Radiation Doses for Dedicated Train Shipments of Consolidated Fuel; Hardware in Drums (Western MRS)

\begin{tabular}{|c|c|c|c|c|}
\hline \multirow[b]{2}{*}{ Population Subgroup } & \multicolumn{3}{|c|}{ Collective Dose ${ }^{(a)}$} & \multirow{2}{*}{$\begin{array}{c}\text { Dose to } \\
\text { Maximally Expo } \\
\text { Individual, } \mathrm{mrem} / \mathrm{yr}\end{array}$} \\
\hline & $\begin{array}{l}\text { Per-Shipment } \\
\text { Dose Person-mrem }\end{array}$ & $\begin{array}{l}\text { Person-mrem } \\
\text { per MTU }\end{array}$ & $\begin{array}{r}\text { Annual Dose, } \\
\text { Person-rem/yr } \\
\end{array}$ & \\
\hline $\begin{array}{l}\text { Transport Workers } \\
\text { Train crew } \\
\text { Handlers } \\
\text { Yard crew } \\
\text { Escorts } \\
\text { Inspectors }\end{array}$ & $\begin{array}{r}15.75 \\
7.97 \\
6.71 \\
17.10 \\
5.06 \\
\end{array}$ & $\begin{array}{l}0.12 \\
0.06 \\
0.05 \\
0.13 \\
0.04 \\
\end{array}$ & $\begin{array}{l}0.36 \\
0.18 \\
0.16 \\
0.40 \\
0.12 \\
\end{array}$ & $\begin{array}{r}19.32 \\
3.42 \\
0.32 \\
52.44 \\
13.11 \\
\end{array}$ \\
\hline $\begin{array}{l}\text { Total Transport } \\
\text { Workers }\end{array}$ & 52.60 & 0.41 & 1.22 & NA \\
\hline Public & 49.39 & 0.38 & 1.14 & $0.23 / 1.04^{(d)}$ \\
\hline Grand Total & 101.99 & 0.79 & 2.36 & NA \\
\hline
\end{tabular}

NA $=$ Not Applicable

(a) Columns may not sum correctly because of round-off.

(b) Based on 129.36 MTU PWR fuel per shipment.

(c) Based on annual shipment quantities given in Table C.25.

(d) First value is the maximum public exposure at stops. The second value is the maximum public exposure to persons residing near the transport route. 
IABLE C.27. In-Transit Dose Calculations for Dedicated Train Shipments of Unconsolidated Fuel (Western MRS)

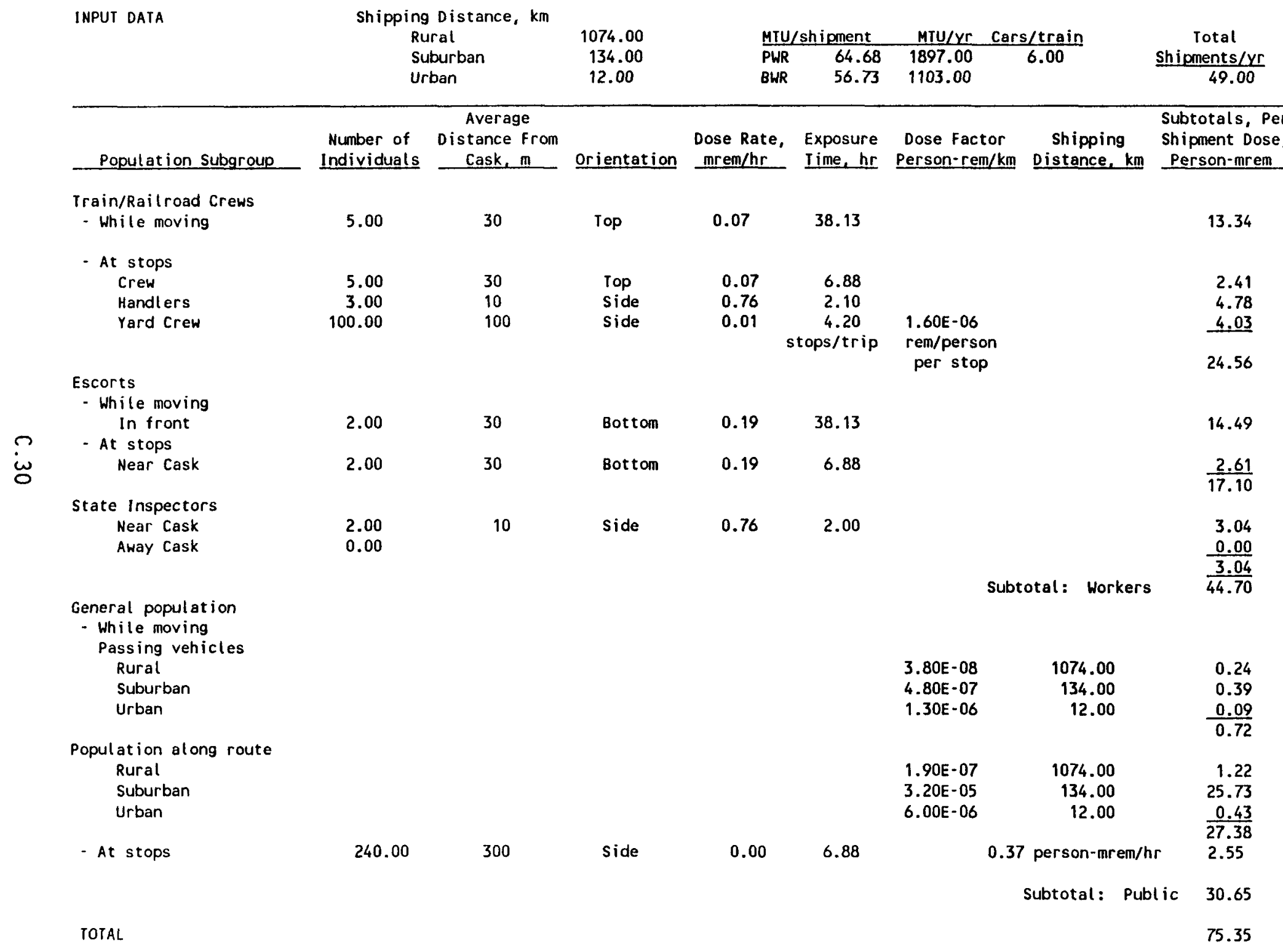


TABLE C.28. Summary of Estimated In-Transit Radiation Doses for Dedicated Train Shipments of Unconsolidated Fuel (Western MRS)

\begin{tabular}{|c|c|c|c|c|}
\hline \multirow{2}{*}{ Population Subgroup } & \multicolumn{3}{|c|}{ Collective Dose ${ }^{(a)}$} & \multirow{2}{*}{$\begin{array}{c}\text { Dose to } \\
\text { Maximally Expos } \\
\text { Individual, mrem/yr }\end{array}$} \\
\hline & $\begin{array}{c}\text { Per-Shipment } \\
\text { Dose Person-mrem }\end{array}$ & $\begin{array}{l}\text { Person-mrem } \\
\text { per MTU }{ }^{(b)}\end{array}$ & $\begin{array}{r}\text { Annual Dose, } \\
\text { Person-rem/yr } \\
\end{array}$ & \\
\hline $\begin{array}{l}\text { Transport Workers } \\
\text { Train crew } \\
\text { Handlers } \\
\text { Yard crew } \\
\text { Escorts } \\
\text { Inspectors }\end{array}$ & $\begin{array}{r}15.75 \\
4.78 \\
4.03 \\
17.10 \\
3.04 \\
\end{array}$ & $\begin{array}{l}0.24 \\
0.07 \\
0.06 \\
0.26 \\
0.05 \\
\end{array}$ & $\begin{array}{l}0.77 \\
0.23 \\
0.20 \\
0.83 \\
0.15\end{array}$ & $\begin{array}{r}41.16 \\
6.84 \\
0.69 \\
111.72 \\
27.93 \\
\end{array}$ \\
\hline $\begin{array}{l}\text { Total Transport } \\
\text { Workers }\end{array}$ & 44.70 & 0.69 & 2.18 & NA \\
\hline Public & 30.65 & 0.47 & 1.50 & $0.49 / 2.21^{(\mathrm{d})}$ \\
\hline Grand Total & 75.35 & 1.17 & 3.68 & NA \\
\hline \multicolumn{5}{|c|}{$\begin{array}{l}\text { NA = Not Applicable } \\
\text { (a) Columns may not sum correctly because of round-off. } \\
\text { (b) Based on } 64.68 \text { MTU PWR fuel per shipment. } \\
\text { (c) Based on annual shipment quantities given in Table C. } 27 \text {. } \\
\text { (d) First value is the maximum public exposure at stops. The second value is the maximum public }\end{array}$} \\
\hline
\end{tabular}




\section{DISTRIBUTION}

No. of

Copies

OFFSITE

12 DOE/Office of Scientific and Technical Information

8 Office of Civilian Radioactive Waste Management

U.S. Department of Energy 1000 Independence Avenue, SW Washington, D.C. 20585

ATTN: J. Carlson

M. Conroy

W. Lake

W. Lemeshewsky

R. Milner

V. Trebules

E. Turner

J. Williams

K. Grassmeier

Yucca Mountain Project office

U.S. Department of Energy

P.0. Box 98518

Las Vega, NV 89193-8518

M. Klimas

DOE-Chicago Field Office

U.S. Department of Energy

Transportation Program office 9800 South Cass Avenue

Argonne, IL 60439

M. Fisher

DOE-Idaho Field office

U.S. Department of Energy

550 Second Street

Idaho Falls, ID 83401
No. of

Copies

\section{J. Strahl}

Battelle Pacific Northwest Laboratories

370 L'Enfant Promenade, Suite 900

Washington, D.C. 20024-2115

3 Oak Ridge National Laboratory

P.0. Box 2008

Oak Ridge, TN 37831

ATTN: D. Joy

R. Pope

R. Raw1

2 Sandia National Laboratory

P.0. Box 5800

A)buquerque, NM 87185

ATTN: R. Luna

T. Sanders

2 Science Applications International Corporation

Transportation and Operations

P.0. Box 2501

Oak Ridge, TN 37831

ATTN: R. Best

3 Roy F. Weston Company, Inc.

955 L'Enfant Plaza, SW

Washington, D.C. 20024

ATTN: P. Bolton

J. Richardson

R. Hahn 
No. of

Copies

\section{OFFSITE}

2 E. J. Bentz \& Associates, Inc. 6090B Franconia Rd

Alexandria, VA 22310

ATTN: E. Bentz

R. Peterson

K. Henry

EG\&G Idaho, Inc.

P.0. Box 1625

Idaho Falls, ID 83415

4 TRW Environmental Safety

Systems Inc.

2650 Park Tower Drive

Suite 800

Vienna, VA 22180

ATTN: B. Teer

D. Dawson

D. Johnson

J. Mayer

P. Standish, TMSSC Westinghouse Electric Company 101 Convention Center Drive

Las Vegas, NV 89109

B. Wakeman

Virginia Power

Innsbrook Technical Center

5000 Dominion Blvd.

Glen Allen, VA 23060
No. of

Copies

ONSITE

3 DOE-Richland Field Office

D. Trader

D. Langstaff

J. Sutey

Westinghouse Hanford Company

J. Lavender

17 Pacific Northwest Laboratory

P. Daling

C. Hostick

G. McNair

D. Payson

$K$. Schneider

S. Short

R. Smith (5)

Publishing Coordination

Technical Report Files (5) 